\title{
Protection of \\ Intellectual, Biological and Cultural Property in Papua New Guinea
}




\section{Protection of \\ Intellectual, Biological and Cultural Property in Papua New Guinea}

Kathy Whimp and Mark Busse Editors

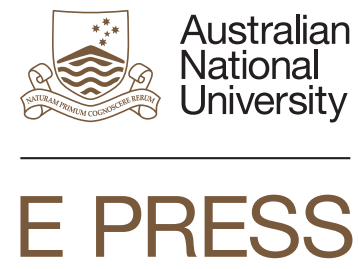




\section{ANU}

E PRESS

Published by ANU E Press

The Australian National University

Canberra ACT 0200, Australia

Email: anuepress@anu.edu.au

This title is also available online at http://epress.anu.edu.au

National Library of Australia Cataloguing-in-Publication entry

Title: Protection of intellectual, biological and cultural property in Papua New Guinea / edited by Kathy Whimp and Mark Busse.

ISBN: 9781922144928 (paperback) 9781922144935 (eBook)

Notes: Includes index.

Subjects: Intellectual property--Papua New Guinea.

Cultural property--Papua New Guinea.

Biotechnology--Papua New Guinea.

Other Authors/Contributors:

Whimp, Kathy, editor.

Busse, Mark, editor.

Dewey Number: $\quad 346.953048$

All rights reserved. No part of this publication may be reproduced, stored in a retrieval system or transmitted in any form or by any means, electronic, mechanical, photocopying or otherwise, without the prior permission of the publisher.

Printed by Griffin Press

First published by Asia Pacific Press, 2000

This edition (C) 2013 ANU E Press 


\section{Contents}

Abbreviations vii

Contributors ix

Foreword by Meg Taylor $\quad$ xi

Acknowledgements xiv

1. Introduction 1

Mark Busse and Kathy Whimp

2. Intellectual property rights in Papua New Guinea 29 Leslie Harroun

3. Multiple perspectives on intellectual property 47 Marilyn Strathern

4. Copyrighting traditional Tolai knowledge? Jacob L. Simet

5. The National Cultural Property (Preservation) Act 81 Mark Busse

6. Ownership of ideas and things: a case study of the politics of the Kuk prehistoric site John D. Muke

7. Stealing music from/in Papua New Guinea Don Niles

8. Plant genetic resources of Papua New Guinea: some thoughts on intellectual property rights Rosa Kambuou

9. Genetic, biochemical and medicinal resources: how much can we own, protect and receive credit for?

Lohi Matainaho 
10. Access to genetic resources: legal and policy issues 143 Kathy Whimp

11. The search for an interim solution Brendan Tobin

$\begin{array}{lr}\text { Appendix } & 184 \\ \text { Summaries of small group discussions } & 200 \\ \text { References } & 212 \\ \quad \text { Recordings referred to in text } & 213\end{array}$ 


\section{Abbreviations}

ARA academic research agreement

ASOMPS Asian Symposium on Medicinal Plants and Spices

CITES Convention on International Trade in Endangered Species of Wild Fauna and Flora

CBD Convention on Biological Diversity

CGIAR Consultative Group on International Agricultural Research

CRA commercial research agreement

DEC Department of Environment and Conservation (Papua New Guinea)

DENR Department of Environment and Natural Resources (Philippines)

EU European Union

FAO Food and Agriculture Organisation

FSP/PNG Foundation of Peoples of the South Pacific/ Papua New Guinea Inc.

GATT General Agreement on Tariffs and Trade

HIV human immunodeficiency virus

IACBGR Inter-agency Committee on Biological and Genetic Resources (Philippines)

ICBG International Collaborative Biodiversity Group

ILE inter-linked economies

ILG incorporated land group

IPR intellectual property rights

IUCN International Union for the Conservation of Nature

MTA materials transfer agreement

NAQIA National Agriculture Quarantine and Inspection Authority (Papua New Guinea)

NCC National Cultural Commission

NCP Act National Cultural Property (Preservation) Act (Papua New Guinea)

$\mathrm{NGO}$ non government organisation 


\begin{tabular}{|c|c|}
\hline PBR & plant breeders rights \\
\hline PGR & plant genetic resources \\
\hline PIC & prior informed consent \\
\hline RCF & Research and Conservation Foundation \\
\hline TRIPs & $\begin{array}{l}\text { Agreement on Trade-Related Aspects of Intellectual } \\
\text { Property }\end{array}$ \\
\hline TRR & traditional resource rights \\
\hline UNCED & $\begin{array}{l}\text { United Nations Conference on Environment and } \\
\text { Development }\end{array}$ \\
\hline UNESCO & United Nations Economic Social and Cultural Organisation \\
\hline UPOV & Union for Protection of New Varieties of Plants \\
\hline USDA/ARS & $\begin{array}{l}\text { United States Department of Agriculture, Agricultural } \\
\text { Research Service }\end{array}$ \\
\hline VAT & value added tax \\
\hline WTO & World Trade Organisation \\
\hline WIPO & World Intellectual Property Organisation \\
\hline WGTRR & Working Group on Traditional Resource Rights \\
\hline
\end{tabular}




\section{Contributors}

Mark Busse is a Research Associate at the Macmillan Brown Centre for Pacific Studies at the University of Canterbury in Christchurch, New Zealand. From 1990 to 1998 he was employed by the Papua New Guinea National Musuem, first as Curator of Anthropology and then as Assistant Director for Science, Research and Consultancy.

Leslie Harroun is presently the head of the Environment Program for the Oak Foundation in Boston, Massachusetts. She spent a year in Papua New Guinea as a Fullbright Scholar working on biodiversity prospecting issues, and has worked for a number of years in conservation and sustainable development.

Rosa Kambuou is Principal Scientist for Plant Genetic Resources at the National Agricultural Research Institute and Research Program Leader for the Dry-lowlands Research Program based at Laloki Agricultural Research Station near Port Moresby in Papua New Guinea. Her interests are in conservation and sustainable utilisation of indigenous food crops, and she has a particular interest in intellectual property and the development of a sui generis system for protection of traditional farmers' rights to landraces.

Lohi Matainaho is Senior Lecturer in Pharmacology and Head of the Department of Basic Medical Sciences at the Faculty of Medicine, University of Papua New Guinea. He holds a doctorate in pharmacology from the University of Queensland and is chair of the Technical Steering Committee of the Papua New Guinea Biodiversity Network (PNG BioNet), which was established by the Papua New Guinea Government to provide a framework for the development of conservation-based industries.

John Muke is head of Archaeology within the Department of Anthropology at the University of Papua New Guinea. He holds a doctorate in prehistory from St John's College at the University of Cambridge and has conducted extensive archaeological and anthropological field work in Papua New Guinea, including a number 
of visits to the Kuk early agricultural site. His research interests include the preservation of the Kuk site as a world Heritage site, tribal warfare and peace-making, Highland elections and politics, and urban squatter settlements.

Don Niles has been an ethnomusicologist at the Institute of Papua New Guinea Studies since 1979. He is involved in research into all types of Papua New Guinea music and is the editor of the Institute's monograph series and journal on music.

Jacob Simet is Executive Director of the National Cultural Commission of Papua New Guinea, and is responsible for the administration of the National Cultural Property Preservation Act. He holds a doctorate in anthropology from The Australian National University, Canberra.

Marilyn Strathern is Professor of Social Anthropology at the University of Cambridge. She lived and worked in Papua New Gunea in the 1960s and 1970s and has retained her interest in Melanesian ethnography.

Meg Taylor is presently the Compliance Advisor Ombudsman for the International Finance Corporation. She is a lawyer with a long interest in conservation and resource development issues in Papua New Guinea. From 1989 to 1994 she was Papua New Guinea's Ambassador to the United States. Since then she has served on the boards of the World Wildlife Fund USA and the World Resources Institute and was a member of the World Forestry Commission as well as sitting on the boards of several companies in the natural resources, financial and agricultural sectors. She is a founding member of the board of Conservation Melanesia.

Brendan Tobin is Coordinator of the Asociacion para la Defensa de los Derechos Naturales in Lima, Peru. He has worked on issues of biodiversity prospecting and access to biological resources for a number of years both internationally and in South America.

Kathy Whimp is an Australian lawyer who specialises in legal policy development in conservation, environment and natural resource development in the Pacific. She has worked with national and provincial governments in Papua New Guinea since 1985 and has provided technical advice to the PNG Forest Authority and the Department of Environment and Conservation. Her research interests include mechanisms for the incorporation of customary landowner groups and compensation for resource development. 


\section{Foreword}

In 1992, Papua New Guinea signed the Convention on Biological Diversity. When we were planning this seminar in 1997 it became clear that many of the requirements for the implementation of the Convention had still not been addressed. Many of the issues surrounding the Convention's implementation - the development of legal and policy frameworks for protection of cultural property and indigenous knowledge of medicinal resources, rights to the ownership of plant cultivars, the 'fair and equitable sharing of the benefits arising out of the utilisation of genetic resources' and measures to 'respect, preserve and maintain knowledge, innovation and practices of indigenous and local communities embodying traditional lifestyles that are relevant for conservation and sustainable use of biological diversity'- had not been discussed in our own, unique context. It was clear that our responses to these issues of global significance needed to incorporate specifically Papua New Guinean perspectives.

Our greatest concern in stimulating discussion at the seminar was to ensure that some of the more fundamental differences between the North and the South were discussed and considered before Papua New Guinea adopted new intellectual property laws. Intellectual property rights regimes are one area in which the priorities and perspectives of the North and the South are thrown most starkly into contrast. The stimulus for these debates was the adoption in 1995 of the Agreement on Trade-Related Aspects of Intellectual Property under the auspices of the World Trade Organisation. This Agreement requires all member nations to adopt intellectual property laws within a certain time frame, with some leeway provided to developing countries to meet this requirement. As a member of the World Trade Organisation, Papua New Guinea is required to comply with the Agreement.

At the time the seminar was held, Papua New Guinea had just become a member of the World Intellectual Property Organisation, and the World Trade Organisation and the World Intellectual Property Organisation had begun a program of technical cooperation to assist in the development of intellectual property laws for Papua New Guinea. 
The technical cooperation focused very much on conventional intellectual property rights regimes like copyright, patents, plant breeders rights and trade secrets. It was clear from the papers and the discussion at the seminar that knowledge and ownership are approached very differently in Melanesian societies from the way they are handled in the jurisdictions of developed countries, and that our own approaches to the sharing of ownership and knowledge do not sit easily within a western legal framework.

In recent months, the debates over free trade and globalisation have become a heated issue in the North as well as in the South. Concerns range across a wide spectrum of issues, from labour markets to forestry. The issues for Papua New Guinea are also varied, but for the most part they centre on the question of access to resources-access to biological resources and access to the resources of knowledge within our communities and villages. Today, Papua New Guinea is just beginning to formulate rules about what happens when a bioprospector wishes to explore in Papua New Guinea. Legislation covers mining and petroleum exploration but there are no laws or rules for engagement with those who want to exploit the biological resources of our country. These issues are all the more difficult because of our complex land tenure systems, communal ownership of resources, and the distribution of ownership of biological resources and knowledge across many communities. These aspects of Melanesian society need to be carefully considered before we simply follow the lead of developed countries and buy into an intellectual property rights regime that does not address the issues that are important to us. In the development of patent and copyright legislation, we should be mindful that the agendas of the developed countries who provide us with technical assistance are not necessarily aligned with our own priorities.

Since the seminar, our own institutions have begun, in a range of ways, to explore issues and to try practical approaches. A committee, the PNG Bionet, has been established to coordinate government policy. It has negotiated a biological exploration agreement with the Australian Commonwealth Scientific and Industrial Research Organisation. A similar agreement, described by Lohi Matainaho in his chapter, has been negotiated between the University of Papua New Guinea and the US National Cancer Institute. These agreements provide for local resourceowners to be involved. However, we are yet to experience the more 
challenging scenario in which a major discovery is exploited. Such a situation is likely to raise real questions about how to equitably distribute benefits to the many stakeholders with an interest in a discovery.

I am extremely pleased that the seminar at which these issues were first discussed in a national forum has served as a springboard for subsequent developments. It is to be hoped that the publication of this book will serve to stimulate further consideration of these issues that are of such serious concern for our future.

Meg Taylor

Chairperson, Conservation Melanesia 


\section{Acknowledgements}

The chapters in this volume were first presented at a seminar on intellectual property rights in biological and cultural materials, held in Port Moresby in August 1997. The seminar was arranged by Conservation Melanesia, a NGO based in PNG which runs a number of programs concerned with conservation and sustainable development. Conservation Melanesia wishes to acknowledge the contributions of the National Research Institute, University of Papua New Guinea, Institute of Medical Research, PNG Department of Foreign Affairs and Trade and the PNG Biodiversity Data Management Project (implemented by the Department of Environment and Conservation and funded by the United Nations Development Programme) in supporting the staging of the seminar.

A number of individuals gave generously of their time in organising the workshop: Lance Hill and John Nonggorr from UPNG, Dr Beno Boeha, Dr Thomas Nen and Kathy Lepani from NRI, Carroll Poyep and Silina Tagagau from Conservation Melanesia, Mike Hedemark from the Conservation Resource Centre, John Genolagani from the Department of Environment and Conservation, Meg Taylor from Gadens Lawyers and Mark Busse from the National Museum made up the organising committee. Michael Alpers from the Institute of Medical Research assisted with organisation both before and during the seminar. Leslie Harroun worked tirelessly to coordinate the contributions of various participants while she was engaged on a Fulbright Scholarship in PNG. Her participation was made possible with the support of the Cristensen Research Institute in Papua New Guinea and the US Fulbright Program.

The Macmillan Brown Centre for Pacific Studies at the University of Canterbury generously provided facilities for Mark Busse during the editing phase. Assistance of others in the editing process is also gratefully acknowledged. Leslie Harroun, Lance Hill and Michael Alpers assisted with early edits of a number of chapters. Anita Van Breda at Conservation Melanesia supported and sustained the effort. Jack Golson and Colin Filer undertook painstaking revisions of one chapter and provided comments. Graham Dutfield and Darell Posey from the Working Group on Traditional Resource Rights kindly agreed to let us use their material and assisted us to chase elusive references. Thanks also go to the publications team at Asia Pacific Press.

Kathy Whimp

Mark Busse 


\section{1 \\ Introduction}

\section{Mark Busse and Kathy Whimp}

\section{'Lost tribes, lost knowledge'}

In September 1991, the cover of Time magazine featured the portrait of a man, identified only as 'Highland Tribesman, Papua New Guinea', wearing cuscus fur on his head and a stick through his pierced septum. In addition to the question 'Is the CIA Obsolete?' at the top of the page, the cover carried the title 'Lost Tribes, Lost Knowledge' and explained that 'When native cultures disappear, so does a trove of scientific and medical wisdom'.

The cover story by Eugene Linden presented a popular view of indigenous knowledge, asserting that 'an enormous trove of wisdom' is 'stored in the memories of elders, healers, midwives, farmers, fishermen and hunters in the estimated 15,000 cultures remaining on earth'. For Linden, 'This largely undocumented knowledge base is humanity's lifeline to a time when people accepted nature's authority and learned through trial, error and observation'.

According to Time, 'Western contempt' for indigenous knowledge has gradually changed to a 'growing appreciation' of the value of indigenous knowledge. This change has come about because of a recognition that indigenous botanical and medical knowledge can assist in the search for plants with chemical properties useful in the treatment of AIDS and cancer, that the variety of crops grown by traditional farmers and the knowledge they have of those crops is critical for preserving the genetic diversity needed to resist insects and diseases, and that in an age of 
global tourism 'An indigenous culture can itself be a marketable commodity if handled with respect and sensitivity'. The recognition of the value of indigenous peoples and their knowledge and ways of life, according to Linden, is a necessary step 'If the developed world is to help indigenous peoples preserve their heritage' (Linden 1991:52-5). But 'value' is always value for someone, and in the movement to preserve indigenous knowledge the value that matters is most often the commercial value of that knowledge for people in industrialised countries.

Linden explained the loss of indigenous knowledge in terms of the inherent glamour and attractiveness of Western ways of life, especially for young people, and the destabilising effects of education and money which undermine the perceived wisdom and authority of the elders. Such an explanation sets up a false dichotomy between tradition and modernity, and ignores the colonial histories of most developing countries as well as the continuing political and economic inequalities between industrialised and non-industrialised countries. The loss of indigenous knowledge, according to Time, is the inevitable result of individual choice, and saving indigenous knowledge will require the assistance of scholars and researchers motivated by the economic value of that knowledge for the West.

Like the images that accompanied the article, in which people from various parts of the world were photographed in front of the same studio backdrop, Time presented a decontextualised idea of indigenous knowledge in which knowledge can be saved in isolation from the cultural and social contexts in which it is produced and used. ${ }^{1}$ As Linden (1991:52) noted, 'Scientists are learning to look past the myth, superstition and ritual that often conceal the hard-won insights of indigenous peoples'. The dangers of such an approach have been described by Peter Dwyer (1994) in an essay on the use of indigenous knowledge by Western conservationists. Dwyer argued that, by representing indigenous environmental knowledge as the basis for indigenous conservation of the environment, conservationists ignore critical differences in underlying assumptions and purposes between themselves and indigenous peoples (for example, global vs. local concerns). In so doing, conservationists place indigenous people in untenable positions. As Dwyer (1994:95) put it, 'In the final analysis the elders are acknowledged as wise only in the circumstance that they speak as we wish to hear them'. 
While unexamined social evolutionary assumptions (assuming that contemporary indigenous peoples and their knowledge are somehow a link with the past), decontextualised ideas of indigenous knowledge as information 'stored' in people's memories, assumptions that indigenous peoples are not capable of preserving their own heritage, and the linking of preservation to commercial value remain common themes in contemporary discussions of indigenous knowledge, what is remarkably absent in the Time magazine article, at least from today's perspective, is any discussion of intellectual property rights. ${ }^{2}$ It is hard to imagine that a similar article published today could so conspicuously ignore issues of property and ownership. This reflects a critical change in the last decade, a change that the essays in this book document in the context of Papua New Guinea.

\section{Protecting intellectual, biological and cultural property in Papua New Guinea}

The chapters in this book were presented at a conference on intellectual, biological and cultural property that was held in Port Moresby in August 1997. They raise issues that are critical both for Papua New Guinea and for other developing countries. With the exception of Brendan Tobin's chapter (which uses the analysis of an intellectual property agreement in the Peruvian Amazon to make general suggestions for legal frameworks within which intellectual property can be transacted), the essays reflect the Papua New Guinea context in which they were written, not only in their content but also in the social and historical contexts that are taken for granted-for example, understandings about social relations between persons; ideas about relationships between persons and things; Papua New Guinea's history of British, German and Australian colonialism; and the powerful economic position that Australia continues to have in Papua New Guinea.

The diverse chapters in this book are linked by their concern with the concept of property and property rights in intangible things. While they emerged from the particularities of Papua New Guinea, the essays also take up wider debates at the cutting edge of the development of international property law including globalisation and deregulation of trade, the balance of economic interests between industrialised and developing countries, and the rights of indigenous peoples both internationally and in relation to the nation states of which they are 
citizens. There is much room for confusion and misunderstanding in determining how these questions should be answered. In taking up these issues, the essays bring into focus the question of how such developments might be applied in Papua New Guinea.

In this introduction we seek to provide historical background and to illuminate some critical distinctions and perspectives on intellectual property which will set the scene for the issues raised in the following chapters. We begin with a brief overview of the development of ideas about property and intellectual property in English law. The relevance of this lies in the Papua New Guinea Constitution which explicitly includes both custom and the principles and rules of common law and equity in England' (as they existed immediately before Papua New Guinea's independence in 1975) as the underlying law of the country. ${ }^{3}$ We then discuss the major international treaties and conventions regarding intellectual property and their significance for Papua New Guinea. We then turn to indigenous Papua New Guinean ideas about property and intellectual property, and a discussion of the status of custom in Papua New Guinea law, before concluding with comments on alternatives to the prevailing paradigm of intellectual property rights.

\section{Property and property rights}

In everyday contemporary English usage, the word property refers to objects or things, or to relationships between persons and things. Things and relations between persons and things constitute the two parts of the Oxford English Dictionary definition of property as 'owning, being owned; things owned, possession(s)'. ${ }^{4}$

While common usage emphasises property as objects or things, English-speaking scholars have generally considered property in terms of relations between persons. In this view, property is an abstraction rather than a thing. In English law, and in many of the legal traditions derived from English law, property is a right in something (or to something) rather than the thing itself. To own property is to have an enforceable claim (that is, a right) to some use or benefit of some thing. The idea of an enforceable claim - be it enforceable by custom, convention, or lawdistinguishes property from mere occupancy or momentary physical possession (Macpherson 1978:3).

In this framework the claims that distinguish property from occupation or possession are claims in relation to other persons. When a 
person buys a house or a car, what she or he purchases is the legal title, the enforceable right, to the tangible object. In the case of private property, such rights are exclusive or discriminatory in that they exclude others from using or benefiting from the object in question. In the case of common property, on the other hand, such rights are inclusive in that they guarantee that certain persons will not be excluded from the use or benefit of a tangible object. In this view, a system of property is a system of rights of each person in relation to other persons. In other words, property is a relation between persons with respect to things (Macpherson 1978:3-5; Hann 1998:4-5).

According to Macpherson (1978:7), the contemporary everyday use of 'property' to refer to things emerged in the seventeenth century with the spread of capitalist market economies and 'the replacement of old limited rights in land and other valuable things by virtually unlimited rights'. Prior to this, it was well understood that property was a right in something' rather than the thing itself. This understanding of property as rights stemmed from feudal ideas about land in which simultaneous multiple claims were recognised and in which any one person's claims were limited and not fully disposable. With the spread of capitalist economies, however, limited rights in land were increasingly replaced with almost unlimited rights including the right to sell or otherwise dispose of land. As these rights became more absolute, Macpherson (1978:7-8) argued

It appeared to be the things themselves, not just rights in them, that were exchanged in the market. In fact the difference was not that things rather than rights were exchanged, but that previously un-saleable rights in things were now saleable; or, to put it differently, that limited and not always saleable rights in things were being replaced by virtually unlimited and saleable rights to things (emphasis in the original).

Alan Macfarlane (1998) has recently painted a more complex picture of the history of European legal thinking about property. He contrasted Roman law and English feudal law regarding property in the following terms

Roman lawyers saw the thing as property and it could be divided almost ad infinitum. Thus a piece of land could be divided and sub-divided among heirs again and again. Feudal lawyers on the other hand saw the thing as indivisible, but the rights in it, that is the relationships between people, the bundle of social ties between people and resources, were almost infinitely expandable (Macfarlane 1998:113; emphasis in the original). 
At the end of the twelfth century, land in most parts of Europe was thought of in these feudal terms. Around 1200, however, English law regarding property began to diverge from property laws in other parts of Europe in two critical ways. First, land in England became freely alienable. Whereas in other parts of Europe land was divided into small peasant family properties which could not easily be alienated because of the multiple claims that people had to them, by the thirteenth century in England people at all levels of society could alienate their land. Multiple claims were replaced by individual claims, the right to alienate land was added to the existing bundle of rights, and property relations became relations among persons. The second divergence between English property law and laws concerning property elsewhere in Europe resulted from the reintroduction of Roman law in most parts of Continental Europe between the thirteenth and fifteenth centuries. The renewed influence of Roman legal ideas, which are reflected in the present-day legal codes of countries such as France, Germany, Switzerland and Italy, included a tendency 'to identify ownership with the thing owned, and to limit [the] definition of things to movable or immovable property, as opposed to more abstract rights' (Macfarlane 1998:111). In contrast, English law has developed from the tenures of medieval feudalism and has been more ready to analyse ownership in terms of bundles of rights, obligations and interpersonal relations arising from the control and enjoyment of property' (Macfarlane 1998:111-2).

The point here is not the detail of European laws about property, but the fact that those laws have changed over time and in relation to broader social and economic changes. The divergence between property laws at the beginning of the thirteenth century, for example, reflected differences in the organisation of agriculture in England and on the Continent which began during the second half of the twelfth century. More recently, the expansion of property rights corresponded to the spread of capitalist economies (Macfarlane 1998:111).

\section{Intellectual property}

Intellectual property is generally defined as property that is intangible or which has no physical form. The challenges posed by this intangibility have been central to the history of ideas about intellectual property and debates about its legal status. The contemporary intellectual property categories of copyright, patent, trademark and 
trade secrets, for example, which are described in detail in Leslie Harroun's contribution to this book, did not become fixed until the middle of the nineteenth century and their emergence was part of a critical transformation in how English law dealt with intangible property and rights in what was then called 'mental labour'.

English patent law had its origins in a medieval system of prerogativebased privilege. The English monarch could, usually for a fee, grant an individual or company the exclusive right to undertake various economic activities, for example, the manufacture of certain items (Drahos 1996:29). Successive monarchs abused this system because it was an easy source of revenue, and the English courts responded by striking down the monopolies on the ground that they interfered with freedom of trade. The one exception to this was the monopoly patent, which gave an inventor the exclusive right to reproduce his invention in return for bringing the knowledge about it into the public domain. This was reflected in the Statute of Monopolies which was passed by the English Parliament in 1623 and which made all monopolies void with the exception of patent monopolies.

Like English patent law, English copyright law can be traced to the end of the practice of granting royal monopolies and to changes in the regulation of the book trade at the end of the seventeenth century. Prior to this, the Stationers' Company held a monopoly on printing in England which was granted by the Crown in order to restrict the printing of seditious, heretical, blasphemous and obscene materials. Under the terms of this monopoly, it was an offence to publish a book that had not been approved and registered by the proper authorities. In exchange for accepting censorship on what they could print, the Stationers' Company obtained the commercial protection of an exclusive monopoly over printing. In this system, authors played a very limited role (Lange 1997:76; Sherman and Bently 1999:11; Strong 1997:256-8).

The Stationers' Company lost control of the printing trade when the Licensing Acts which granted their monopoly lapsed in 1695. These Acts were eventually replaced in 1709 by the Act for the Encouragement of Learning, commonly known as the Statute of Anne, which asserted a public interest in writing and publishing to justify an end to the printing monopoly. The expressed purpose of the statute was to encourage the spread of education by providing authors with an incentive to write and publish, and it did this by giving authors the right to control the publication of their own works for a limited period 
of time (either 14 or 28 years depending on the circumstances) after which their rights would lapse (Sherman and Bently 1999:11-12).

Faced with losing their monopoly, the Stationers' Company argued that the rights granted by the Statute of Anne merely supplemented authors' perpetual rights under common law, rights under which authors had previously given permission to the Stationers' Company to print their works. This assertion of perpetual common law rights provoked a lively legal debate during the course of which a wide range of key legal ideas were examined critically and in detail. Central to this debate, which lasted until the mid nineteenth century and laid the foundations of modern intellectual property law, were questions about the extent to which property protection could be extended to intangibles and the nature of mental labour (later called 'creativity') which came to be seen as the link between the various areas of law which granted property rights in intangibles (ibid:13-16, 44).

Fundamental to the debate about the extension of the concept of property to intangibles was a distinction between discovering and creating which, in turn, rested on 'a belief in the existence of an a priori domain, a reservoir from which inventions were drawn' (ibid:44-5). This 'reservoir' was variously called 'tradition', 'nature', 'principles' or 'the laws of science'. Aspects of these domains could be discovered, but they could not be made the subject of property claims (that is, they could not be copyrighted or patented). Thus, electricity could be discovered, but it could not be patented (that is, one could not exclude other people from using electricity or benefiting from it). What could be granted the status of property was the transformation of abstract ideas into material or practical form. What was protected in intellectual property law was the human creativity that transformed 'nature' into products (ibid:44-7).

In discussions of literary property, debate focused on whether the concept of property applied only to the right to print and reprint a particular work or whether it also extended to the ideas and knowledge contained in a written work. A narrow definition of literary property faced the problem of failing to protect an author's rights in cases of abridgement, compilation and translation, while a broader definition opened the problematic possibility of turning ideas and knowledge into property. What emerged from the debate was a definition of literary property as the specific ways in which words were combined in written expression, that is, the precise ways in which ideas and knowledge were 
represented or expressed. Mental labour or creativity (in this case the creativity of the author) was again central to the definition of intellectual property (ibid:19-42).

In thinking about creativity in the Papua New Guinea context, an important aspect to consider is the relationship between tradition and creativity. The creativity of indigenous peoples in the creation of new knowledge or new art forms and styles is sometimes denied or diminished on the grounds that they are simply following their traditions. Popular Western ideas of non-Western peoples as timeless and unchanging (as least prior to Western contact and influence) sit uncomfortably with ideas of individual creativity by indigenous peoples. But the emphasis on the individual as creator that is often found in contemporary Western ideas of authorship and invention are not reflected in earlier discussions of intellectual property. Sherman and Bently (1999:37) stated that

What is striking about much of what was written about intellectual property throughout the eighteenth and nineteenth centuries is how conscious commentators were of the interpersonal nature of creation, of the debt and connection which existed between authors.

Sherman and Bently argued against romanticising the individual as creator and for the need to acknowledge the social and intellectual networks within which creativity takes place. This suggests that far from being part of the 'reservoir' of things that are simply waiting to be discovered, and therefore not amenable to property claims, tradition is a vital part of all creativity.

The legal debates that flowed from the Statute of Anne began with an assertion of a public interest in access to ideas and knowledge. They took for granted a particular shared understanding of mental labour (or creativity) and a historical and legal definition of property as rights in relation to tangible things. The debates transformed both the form and organisation of English intellectual property law as well as the subject matter protected and the role of registration in identifying intellectual property. The present day categories of copyright, patent, trademarks and trade secrets emerged during the course of the debate and were not clearly distinguished and established until the middle of the nineteenth century. Prior to this, there was no consensus as to how to categorise intellectual property, only a general agreement that English law recognised and granted property rights in mental labour. ${ }^{6}$ Similarly, whereas prior to the mid nineteenth century the law was reactive and 
subject specific (for example, it dealt with the printing of designs on fabric, but not the general question of designs), after the mid-nineteenth century intellectual property law was abstract and tried to anticipate issues that would be raised by new forms of tangible property. Whereas earlier English intellectual property law was concerned with issues that the law itself identified as metaphysical (for example, identifying the essence of mental labour or creativity) by 1850 the law had abandoned such philosophical issues and was concerned less with what was embodied in an object than with the object itself and its economic implications. Paralleling this shift to a concern with the economic implications of intellectual property was a shift to the language and concepts of political economy and utilitarianism. Finally, by 1850 the issue of proving rights in intellectual property had become a matter of public concern, and bureaucratic registration identified the limits of intellectual property (Sherman and Bently 1999:3-5).

Sherman and Bently explicitly argued against those who present intellectual property law as if it were a timeless entity that has always existed' and against those who assert that the present-day categories of intellectual property (for example, patents, copyright) are a natural ordering' or the product of a considered philosophical position. Instead, both the general category of intellectual property and more specific categories of intellectual property emerged from a historical process of a period of some 120 years (roughly from 1730 to 1850 ) during which industrial technology and capitalism expanded rapidly, and during which property protection was gradually extended from one type of intangible thing to another on the basis of arguments by analogy. What linked these new forms of property was their relationship to mental labour and creativity (ibid:16). ${ }^{7}$

\section{International treaties and conventions}

While the development of intellectual property law reflected innovations in industrial technology and the expansion of capitalism, expanding international trade during the second half of the nineteenth century and the twentieth century led to the development of international agreements concerning intellectual property, the earliest of which date to the 1880 s.

The primary international treaty covering patents, trademarks and industrial designs is the Paris Convention for the Protection of Industrial Property, first signed in 1883 and most recently revised in 1967. At 
present, approximately 98 countries are signatories, but Papua New Guinea is not among them (Gervais 1998:440). The Convention provides for the standardisation of the procedures for applying for and granting patents. Prior to 1883 , national patent systems varied considerably, and this created obstacles to the international assertion of patent rights. The Convention also stipulates that a signatory country cannot provide less intellectual property protection to residents of other signatory countries than it does to its own citizens. This requirement, which is often called 'national treatment' because foreigners are treated as nationals, together with the Convention's failure to establish standards for national enforcement have often been criticised because countries that do not provide a certain level of intellectual property protection for their own citizens are not required to provide it for foreigners either. A further criticism of the Paris Convention is that it does not provide effective mechanisms for settling disputes which under the Convention are referred to the International Court of Justice (Abbott 1997; Moy 1997).

The principal treaty for protecting copyright is the Berne Convention for the Protection of Literary and Artistic Works which was first signed in 1886. At present, there are some 88 member states, and again Papua New Guinea is not a signatory (Gervais 1998:440). As with the Paris Convention, the Berne Convention requires signatories to extend the same copyright protection to residents of other signatory countries as they grant to their own citizens. It also establishes minimum standards of protection including minimum copyright periods (generally the life of the author plus 50 years) and defines the moral right of authors such as the right to authorise translations and the right to protect the integrity of artistic works. Although the main emphasis is on the rights of authors, these are balanced against concerns about public access to information such as current news or political statements. As in the case of the Paris Convention, disputes over interpretation and enforcement of the Berne Convention can be brought to the International Court of Justice. The Berne Convention, however, does not include either standards for determining when an infringement has occurred or any method for penalising countries that do not meet their treaty obligations (Abbott 1997; Burger 1997).

In the first half of the twentieth century, revisions were made to the Berne Convention, primarily in the direction of expanded rights for authors. In 1967, however, the expansion of authors' rights was opposed 
by developing countries at a meeting of signatory countries held in Stockholm. Developing countries demanded special concessions such as licenses for translations and shorter periods of copyright protection, concessions that would have given them greater and less expensive access to published materials but which would have also significantly weakened the rights of authors. Authors and publishers in developed countries were so opposed to these concessions that in the end no changes were made to the Convention at the Stockholm meeting (Burger 1997:263).

A significant result of the Stockholm meeting, however, was the creation of the World Intellectual Property Organisation (WIPO) which is an agency of the United Nations. Its goals are to encourage the international protection of intellectual property and to administer international treaties and conventions concerned with intellectual property. Thus, the WIPO administers both the Paris Convention and the Berne Convention as well as the Madrid Agreement, which simplifies procedures for filing trademarks in different countries, and the Rome Convention, which provides international protection for performers, phonogram producers and broadcasting organisations. ${ }^{8}$

Conflicting interests between industrialised and less industrialised countries with regard to intellectual property have continued. Developed countries saw the Berne Convention as lacking effective enforcement mechanisms and as unduly subject to the desires of developing countries for less restrictive access to intellectual property. These concerns at least partly explain the recent development of the Agreement on Trade-Related Aspects of Intellectual Property (generally known as the TRIPs Agreement) which is part of the General Agreement on Tariffs and Trade (GATT) (D'Amato and Long 1997:267-8; Long and D'Amato 1997).

The Agreement on Trade-Related Aspects of Intellectual Property was drawn up during the Uruguay Round of Multilateral Trade Negotiations which began in 1986 under the GATT framework. These negotiations also resulted in the formation of the World Trade Organisation (WTO) which came into existence on 1 January 1995. Papua New Guinea joined the WTO in June 1996 and is therefore bound by the Agreement on Trade-Related Aspects of Intellectual Property. The inclusion of intellectual property rights and their enforcement within the Uruguay Round stemmed from proposals by Japan and the United States which were dissatisfied with efforts to resolve intellectual property issues, 
especially disputes, through WIPO. Many less developed countries objected to using GATT to establish international standards in the area of intellectual property, arguing that WIPO was the appropriate forum in which to do this. They viewed GATT, with its emphasis on free trade, as a forum favouring industrialised countries, and they believed that the Paris and Berne Conventions, with their emphasis on national treatment for intellectual property issues, had already resolved the issues with which GATT was proposing to deal (Gervais 1998:3; Long 1997).

The Agreement on Trade-Related Aspects of Intellectual Property both builds on earlier international treaties regarding intellectual property and represents a new departure from them. Most of the substantive provisions of the Paris and Berne Conventions were incorporated into the TRIPs Agreement, although an author's moral rights (as opposed to economic rights) - that is, the right to claim authorship of the work and to object to any distortion, mutilation or other modification of, or other derogatory action in relation to, the said work' (Article 6bis of the Berne Convention) - were not included in the TRIPs Agreement. ${ }^{9}$ But the Agreement on Trade-Related Aspects of Intellectual Property goes beyond the Paris and Berne Conventions by adding new intellectual property rights (such as the protection of confidential information) and, more importantly, by setting out both rules for enforcing intellectual property rights and provisions for dealing with disputes under the integrated dispute settlement system of the WTO. These are significant changes to the international treatment of intellectual property because they highlight the commercial and trade aspects of intellectual property (for example, by insisting that enforcement procedures should not create barriers to legitimate trade) and because they replace a general obligation to provide legal remedies to infringement of intellectual property rights through national legislation with a harmonised set of international legal principles and procedures. As David Demiray (1997:268) has argued

Since the creation of GATT ... intellectual property has undergone a fundamental conceptual change: the emphasis has moved away from sovereign matters-for example, one of protective norms restricted to the territory of the state- to issues of adequate protection of intellectual property rights abroad. As the economic importance of exports has increased, so have the needs for improved extra-territorial protection of intellectual property rights.

Aspects of the TRIPs Agreement of particular importance to Papua New Guinea, with its high levels of biodiversity and large numbers of 
subsistence gardeners and farmers, are the provisions in Article 27 of the Agreement concerning the patenting of animals, plants and plant varieties. Article 27 allows member states to prohibit the patenting of plants and animals other than micro-organisms, and essentially biological processes for the production of plants or animals other than non-biological or microbiological processes'. But Article 27 also states that 'Members shall provide for the protection of plant varieties either by patents or by an effective sui generis [special purpose] system or by any combination thereof'. ${ }^{10}$ In other words, while Papua New Guinea may prohibit the patenting of plants and animals (for example, by multinational pharmaceutical companies), it must recognise and protect the intellectual property rights, either through patents or through a special purpose system, of those who develop new plant varieties. The danger in this requirement lies in the introduction of property rights over plant resources previously thought of as being held in common and in the fact that the requirement ignores the informal agricultural and horticultural systems through which farmers and gardeners in developing countries such as Papua New Guinea breed a wide variety of plants. At the same time, Article 27 provides the possibility that Papua New Guinea could develop a sui generis system of protection that reflects the interests of Papua New Guineans (Posey and Dutfield 1996:102-3).

The centrality of intellectual property issues to contemporary biological concerns was highlighted in the Convention on Biological Diversity (CBD) that emerged from the 1992 World Conference on Environment and Development that was held in Rio de Janeiro. It was highlighted both in the central place of intellectual property in the $\mathrm{CBD}$ and by the fact that the United States refused to sign the Convention believing it would erode conventional patent rights. Article $8(j)$ of the Convention on Biological Diversity specifically obliges contracting parties to

Respect, preserve and maintain knowledge, innovations, and practices of indigenous and local communities embodying traditional lifestyles relevant for the conservation and sustainable use of biological diversity and promote their wider application with the approval and involvement of the holders of such knowledge, innovations and practices and encourage the equitable sharing of the benefits arising from the utilisation of such knowledge, innovations and practices (cited in Posey and Dutfield 1996:104).

Article 16 of the Convention on Biological Diversity also deals with intellectual property issues and requires greater access to and transfer of 
technology, including technology protected by patents and intellectual property laws. In making this requirement, the Convention on Biological Diversity accords the same legal status to the knowledge and technologies of indigenous peoples as it does to Western knowledge and technology. As Darrell Posey and Graham Dutfield have noted

Indigenous and traditional technologies have rarely been considered to be 'technologies' in international parlance. This pattern is part of the larger trend to downgrade, overlook, and minimise the knowledge, innovations, and practices of indigenous peoples. The CBD, however, specifically elevates these elements to a central concern as technologies relevant to the conservation and sustainable use of biological diversity (Posey and Dutfield 1996:106-7).

The Convention on Biological Diversity thus requires contracting parties to provide legal protection for indigenous knowledge, innovations, and practices.

The distinction between discovering and creating remains critical for contemporary discussions of property rights in biological resources. Biological materials were traditionally excluded from property protection under Western law because they are part of nature and not the result of individual creative effort. They could be discovered, but they could not be patented. During the twentieth century, intellectual property law adapted to changing technology and many countries now extend property protection to the products of biotechnological engineering and to new varieties of plants. In recent years there has also been a changing recognition of the rights of nations to exercise sovereignty over 'products of nature' as discussed in Rosa Kambuou's contribution to this book. Much of this change has occurred in the realm of international cooperation between governments in relation to agricultural production and the protection of biodiversity rather than through the adaptation of intellectual property law.

Intellectual property law continues to favour those who have contributed specific mental labour to developing new products from nature, and it accords no rights to those who own or control access to natural resources such as plants that contain chemical compounds useful to pharmaceutical companies. Contemporary discourse emphasises the failure of Western law to recognise the communal rights of indigenous peoples. The idea that the natural world is a reservoir that cannot be the subject of property rights is seen in this context as dovetailing with the economic imperatives of colonial enterprise, and providing a justification for the expropriation of natural resources at the expense of their original 
indigenous custodians. The expansion of intellectual property rights to include those indigenous custodians thus becomes an avenue to right at least in part the wrongs that have created international political and economic inequalities.

This viewpoint sits well with concepts of intellectual property rights. Just as land is returned to those from whom it was stolen, so too can rights to intangible property be returned. But if we expand intellectual property rights to include those outside the realm of inventive labour, who should be included and who should be excluded? This question returns us again to the distinction between intellectual property (such as chemical compounds and gene sequences) and the physical objects (such as plants and other forms of biodiversity) from which they are derived. Where this distinction is blurred, custodianship of the physical objects from which the intangible property is created seems to be a logical nexus of ownership. One might want, for example, to return the proceeds of pharmaceutical discoveries to the communities from which the original plant material was taken. But intellectual property laws as we know them today are precisely about severing the rights to intangible property from the physical objects from which they are derived. After all, intellectual property is thought of as a single object (for example, the copyright for a book or a new plant variety), but the intellectual property may be manifested in millions of physical objects (for example, the physical books or plants).

These issues are confronting governments and researchers today in the course of negotiating agreements which set the framework for the distribution of benefits, as Lohi Matainaho describes in his contribution to this book. His chapter introduces the idea that the value of biological resources might vary depending on the extent of the contribution that local people make to the overall discovery process. In many cases, the contribution may be more than just the plants themselves. Traditional knowledge will often inform researchers about the kinds of species they are looking for. Here the issues become even more complex. While knowledge is clearly something that can be owned, we need to focus on what happens to that knowledge when we subject it to an intellectual property regime which allows knowledge to be alienated as well as protected. Should the alienation of knowledge (which is basic to its commercial value) that might be shared by other peoples be restricted in some way? Intellectual property law has never addressed itself to this question, since it has never catered for communally-owned knowledge. 


\section{Property and intellectual property in Papua New Guinea}

James Carrier (1998:85) has recently noted that anthropologists working in Melanesia have paid little attention to property per se, and this reflects an omission in anthropology generally (Hann 1998). In the case of Papua New Guinea, an exception to Carrier's generalisation is the attention that anthropologists and other researchers have paid to land tenure, although Carrier (1998:85) argued that such studies often take the idea of property for granted and deal primarily with kinship, social organisation and production in relation to land. In summarising studies of land tenure in Papua New Guinea, Thomas Harding noted both that land is often owned by groups rather than individuals and that ideas of land ownership generally exclude two rights which are among the rights included in Western ideas about land ownership: the right to alienate land and the right to receive income from it (1972:604-5).

While ideas about property other than land have not been an explicit focus for researchers in Papua New Guinea, considerable attention has been paid to cultural ideas about what it means to be a person, to relations between persons and things and to the ways in which people transact objects. If the anthropology of Papua New Guinea is not known for its examination of property, it is well known for its examination of exchange, the published literature on which is enormous. ${ }^{11}$

Discussions of exchange in Papua New Guinea have often used a distinction between commodities and gifts-and between commodity economies and gift economies-to characterise differences between economic systems and activities in Western societies and Papua New Guinea societies, respectively. This distinction highlights the fact that exchanges of goods in Western societies serve primarily to establish relations between the objects exchanged by determining their prices and relative values. In contrast, the primary purpose and result of gift exchanges are to establish and maintain relations between persons making such exchanges (Gregory 1982:18-19). ${ }^{12}$

Commodity economies and gift economies thus involve different kinds of relationships between persons with respect to things. In other words, they are based on distinct concepts of property. But they also involve different relationships between persons and things. Alienability and a clear separation between persons and things are fundamental to commodity exchanges, but the power of gift exchanges to create 
enduring social relationships lies precisely in the fact that the objects given are not completely alienated.

In this view, when Highlands men exchange pigs or shells they are not trying to determine the relative prices or values of what they are exchanging. The point is not to establish that a large female pig is worth a particular number of pearl shells. Nor are pigs or shells from one person the same as pigs or shells from another person. The persons giving and receiving the objects are critical to the purpose of the exchange which is not motivated by a desire to maximise the yield or profit from the exchange but by a desire to establish and maintain particular types of social relations (such as peace, alliance, or inequality of rank or prestige) with particular persons. These social relations are mediated through the objects that are given and received, and a significant part of the meaning of those objects lies in the people who produced, owned and gave them.

Carrier (1998:86-8) has recently recast the difference between property relations in Melanesian and Western societies in terms of 'inclusive' and 'exclusive' ideas of property. He argued that Melanesians have an 'inclusive notion of property' in which objects reflect and are embedded in lasting relationships between people involved in the objects' histories. A previous owner of an object continues to be associated with that object even after it leaves his or her possession, and objects are a vital part of a person's relationships with other people. Carrier contrasted this with the 'exclusive form of property' of the modern West in which an object is controlled by and associated with only the person who owns it at the moment.

Having argued for a distinction between inclusive and exclusive property, Carrier also provides a salutary warning against dichotomising and totalising, against imagining that inclusive property is the only way that Melanesians think about objects or that objects in Western societies are only commodities. He pointed out that socially embedded or inclusive ideas of property do not seem to apply when Melanesians act in the urban, capitalist economy. 'Melanesians,' he wrote, 'have commodities and exclusive property just as surely as Westerners have gifts and inclusive property' (Carrier 1998:101). ${ }^{13}$

While English law has been reluctant to extend the concept of property to intangibles, rituals, stories, songs, personal names, artistic designs and specialist knowledge are among the intangibles to which Papua New Guineans claim ownership and which they exchange with 
others. In an essay on Ritual as Intellectual Property, Simon Harrison (1992:234-5) noted that while such intangibles are exchanged as economic goods, they (like all intangible items) are interesting because 'They presuppose a shared universe of information and meaning, and depend upon that universe not only for their value but for their very reality'. But he noted a critical difference in rationale between Western intellectual property law ${ }^{14}$ and Melanesian ideas about the ownership of intangibles, a difference which echoes the distinction between gifts and commodities. Whereas intellectual property law seeks to encourage public disclosure of innovations by protecting the rights (especially the commercial rights) of innovators, the ownership and exchange of intangibles in Melanesia serve primarily to create and maintain social relations such as inequalities in rank and prestige. Western intellectual property law seeks to define products of human creativity that can be alienated from their creators and exchanged for other commodities in a system concerned with establishing the relative values of the objects exchanged. In Papua New Guinea, the ownership of intangibles does not necessarily include the possibility of alienation, and the exchange of intangibles does not determine their value.

At least in some Papua New Guinea societies, the value of knowledge, for example, is inversely related to the number of persons who possess it. The more people who know something, the less significant it is assumed to be. Restricting access to knowledge can reinforce cultural identity and strengthen social hierarchies and inequalities (Harrison 1995:12). The restriction of certain types of knowledge to initiated men in some Papua New Guinea societies strengthens inequalities that exist in other domains between men and women and between senior and junior males (Barth 1975; Whitehead 1986). Knowledge of particular stories, songs, dances, rituals or artistic designs can serve as markers of cultural or group identity, and their use by outsiders without permission is a serious violation of ownership rights (Schwartz 1975). Jacob Simet's essay in this book explores ownership and restrictions on the use of such cultural markers among Tolai of East New Britain.

A consideration of practices associated with intangible property reveals similarities as well as differences in how Westerners and Papua New Guineans deploy, manipulate, and protect knowledge. Harrison (1995:13), for example, has compared the concerns of Manambu clans, software companies, and universities with regard to the management of knowledge. Among the Manambu, who live along the Sepik River, each 
of the various clans has its own secret myths, known only to a few of its senior men. These myths provide the basis for land ownership. On the one hand, the myths cannot be disclosed to outsiders because the outsiders could then use the myths to make their own claims to land. At the same time, a clan must partially disclose its myths so that outsiders will acknowledge the clan's claims to land ownership. In other words, a clan must maintain a balance between disclosure and protection of knowledge, a balance which software companies and universities must also strike if they are to be successful. Software companies must reveal just enough of the knowledge that they create so that they are not marginalised by their competitors while at the same time protecting themselves through secrecy, copyrights and patents from having their ideas stolen. And as education becomes increasingly redefined in commodity terms, with courses as products and students as consumers, universities must both disseminate knowledge and treat that knowledge as a commercial product. Based on this comparison, Harrison (1995:13) concluded that

...all institutions producing and managing knowledge are faced with the same basic dilemma in one form or another. The dilemma is that they depend for their existence both on producing and communicating knowledge and on keeping this knowledge in some respects their property.

Any practical consideration of Papua New Guinean ideas and customs concerning property and intellectual property must consider the country's legal system and the place, or potential place, of custom within that system. Schedule 2 of the Papua New Guinea Constitution states that custom and English common law at the time of independence together make up the country's 'underlying law'. This is one of several types of law identified in Section 9 of the Constitution as comprising Papua New Guinea law as a whole. Schedule 2 states that 'custom is adopted, and shall be applied and enforced, as part of the underlying law' unless the custom is inconsistent with the Constitution or statute law. ${ }^{15}$ Custom takes precedence over common law inasmuch as common law is only applied and enforced if there is no statute law or customary law regarding a particular issue.

Despite the precedence given to custom by the Constitution, Nonggorr (1995) has noted three factors that contribute to custom being relegated in practice to second place behind the common law. First, Section 5 of the Native Customs (Recognition) Act (Chapter 19) requires that customs 'shall be ascertained as though they were matters 
of fact'. In other words, one must first prove in court that a particular custom exists before it can be considered as part of the underlying law. Proving that a custom exists can be onerous and is certainly more difficult than citing a common law principle. As Nonggorr (1995:74) writes

The adopted common law, which finds its origins in customary law as well, is not required to be proved as fact merely because it is readily available in the recorded case law and text books. Yet customary law must not only be proven as fact, it must be tested by the use of common law-based procedure (cf. Ottley 1995:104).

Second, common law often takes precedence over customary law because Papua New Guinea lawyers are trained in common law. Finally, common law is more prominent than customary law, according to Nonggorr (1995:75), 'because of the adoption of common law institutions, systems, and, indeed, the whole economic and political system'.

Village, Local, and District Courts can resolve disputes according to custom, ${ }^{16}$ but these are not the only arenas, or perhaps even the main arenas, in which intellectual property disputes will be heard. In considering laws to explicitly protect rights in intellectual property, it is critical that Papua New Guinean ideas about ownership, property, knowledge, and creativity are taken into account if those laws are to reflect the contemporary social and political contexts in which they will be applied. An important contribution of Leslie Harroun's essay in this book is the point that conventional intellectual property mechanisms do not adequately accommodate communal ownership of property and that access to the protection that such mechanisms afford is limited because of the high transaction costs. The recognition of communal property, including communal intellectual property, must be central to Papua New Guinea intellectual property law, and whatever intellectual property regime is put in place must consider the practical implications of that regime for average Papua New Guineans who want to protect the products of their creativity.

Marilyn Strathern's essay, however, suggests that there may be even more fundamental ways in which Euro-American concepts of property do not sit easily in the Papua New Guinea context. She challenges the very applicability of European concepts of property and knowledge that underpin ideas about intellectual property rights. These concepts are of course changing in industrialised countries even as they are changing in Papua New Guinea. But Western discussions of property have mainly focused on property as things and as social relations between people 
with respect to things. Strathern argues that Papua New Guinean concepts of property introduce a third dimension of property - the process of transaction itself. Papua New Guinean ideas of knowledge and creativity as both socially embedded and transactable would give rise to a system of intellectual property law quite different from the Western one which has increasingly focused on protection for individual rights and on the commodification of the property that is the subject of the right.

The four essays by Jacob Simet, Mark Busse, John Muke, and Don Niles in this book highlight through concrete examples the importance of taking seriously Papua New Guinean ideas about the production and ownership of knowledge and cultural forms in contemporary and increasingly global contexts. Simet shows that Tolai customary law includes restrictions on the use of cultural materials such as songs, designs for dance costumes, and healing practices which are similar in some ways to the protection provided by Western intellectual property law. His chapter is thus a contribution to the development of Papua New Guinea's underlying law concerning intellectual property. In Western law, however, there is a clear distinction between the intellectual property in a painting, for example, and the ownership of the physical object itself. Each involves a distinct set of rights. But it can be difficult to draw this distinction in the Papua New Guinea context notwithstanding the fact that the legal protection of cultural property is narrowly focused on the protection of physical objects, as Busse explains in his essay.

Muke's chapter confronts the complex and difficult subject of the social relations within which knowledge is created and the different expectations that people have about those relations. His discussion of the complex relations among anthropologists, archaeologists and people who live near the Kuk early agricultural site in Western Highlands Province brings us back to the artificial distinction between the expression of ideas in researchers' notebooks, which are protected under conventional copyright law, and the ideas they contain, which are not.

Niles reminds us that the intellectual property laws that Papua New Guinea is obliged to put in place by virtue of its membership in the WTO will regulate relations between Papua New Guineans as well as those with potentially exploitative outsiders. He poses an interesting question in this respect by juxtaposing the theft of Papua New Guinea's traditional music by non-Papua New Guinean performers with two 
other forms of theft-the appropriation by contemporary Papua New Guinean musicians of Western music and of traditional Papua New Guinean music from societies other than their own-and he asks whether such practices should also be controlled.

\section{Beyond intellectual property rights}

The phrase 'intellectual property rights' refers to a set of complex issues of considerable contemporary significance. Current international debates over the sequencing of human genes, the development of the internet, the preservation of cultural heritage, the protection of biodiversity and the development and patenting of new crops and new drugs, all involve, in one way or another, questions of intellectual property. They are linked by legal questions concerning the ownership of intangibles, an area of law that emerged in the context of the expansion of capitalist economies and accelerating technological innovation. But these are not just international issues, they are issues that increasingly confront Papua New Guinea and they call for the development of legal frameworks for relationships, both between Papua New Guineans and between Papua New Guineans and others, with respect to intellectual property. The essays in this book all address concerns for which intellectual property rights are seen as an answer-such as the equitable distribution of the wealth that flows from exploitation of biodiversity and the fundamental right of people to control their cultural heritage-and they are intended as a contribution to emerging debates concerning intellectual property in Papua New Guinea.

The use of 'intellectual property' as a catch-all phrase, however, risks obscuring opportunities for lateral thinking. Some authors, such as Posey and Dutfield (1996), for example, have questioned whether the paradigm of intellectual property rights is the most effective paradigm for defending the rights and resources of indigenous peoples. They note that legal frameworks for intellectual property are increasingly focused on the commercial value of economic property and ignore the moral and political reasons (for example, the desire for self-determination) that may motivate people to want to protect their intellectual property. They also noted that inequalities of power and wealth may make it difficult, if not impossible, for indigenous peoples to defend their intellectual property rights in courts of law. As a result of these difficulties, Posey and Dutfield proposed a shift from intellectual property rights to what they call 'traditional resource rights'. The phrase 'traditional resource rights' 
refers to a bundle of rights-such as human rights, the right to selfdetermination, and the right to give prior informed consent-which are enshrined in international agreements and which can be used as the basis for sui generis systems (Posey and Dutfield 1996:94-6).

There is a growing discussion of sui generis systems of intellectual property rights protection and the hope that they might diminish economic and political inequality by protecting the intangible property that is important to indigenous peoples as well as that which is of commercial value to industrialised countries. Intellectual property laws, however, function in many respects as a global legal system, which is what makes them so powerful. The international conventions and the standardisation of intellectual property law around the world means that they are an effective trans-border means of enforcing private rights. A sui generis system developed in Papua New Guinea would be virtually useless in protecting the exploitation of traditional knowledge elsewhere in the world, unless other countries agreed to adopt similar laws. While the long process of achieving international consensus on a framework for mutual recognition of sui generis systems proceeds, there is an urgent need to find alternative mechanisms.

Many of the problems posed by intellectual property rights for protecting indigenous knowledge might be solved in other ways. The essays by Kathy Whimp and Brendan Tobin in this book explore avenues that might provide a useful approach to controlling how indigenous knowledge is used. Tobin's chapter focuses on licensing as a mechanism for maintaining effective control over indigenous knowledge as trade secrets, while Whimp's discusses the use of systems for governing access to, and use of, indigenous knowledge and biological resources. Access regimes essentially establish national gate-keeping systems that ensure that just terms prevail when indigenous knowledge or biological resources are used. Combined with contractual provisions that are enforceable under international law, they can be a strong lever for negotiating equitable benefit sharing arrangements.

The development of mechanisms for protecting intellectual, biological and cultural property in Papua New Guinea, whether through access regimes, sui generis systems or more conventional intellectual property laws, requires an understanding of complex and interrelated legal, commercial, social and philosophical issues. Fundamental to these issues are Papua New Guinean ideas about creativity and the production of knowledge, and about relationships between persons with respect to 
knowledge and the products of creative activity. On-going debates about such ideas have been critical in the development of Western intellectual property laws and practices, and the results of those debates can be seen in the distinction between discovering and creating, in the granting of copyright to the expression of ideas rather than to the ideas themselves, in the encouragement of innovation through restrictions on access to the results of innovations, and in the balancing of intellectual property interests against the benefits of creative activities to society as a whole. Contemporary Western treatments of intellectual property-whether encoded in varying national laws or international agreements such as TRIPs-are, however, neither intrinsic to ideas of intangible property nor historically inevitable. They are rather responses to changes in technology, economy and society. Their applicability to contemporary circumstances in Papua New Guinea is a central theme in the essays that comprise this volume.

\section{Notes}

1 At one point, Linden (1991:54) did state that "While some [traditional knowledge] can be gathered in interviews and stored on tape, much information is seamlessly interwoven with a way of life. Boston anthropologist Jason Clay therefore insists that knowledge is best kept alive in the culture that produced it'. But this was not the general approach taken in the article.

2 Only at one point does Linden (1991:54) alluded to the issue of property. Noting that a study sponsored by the US National Cancer Institute had identified some chemical compounds that appeared promising for the treatment of AIDS and cancer, Linden stated, 'If any of them turn out to be useful as medicines, the country from which the plant came would get a cut of the profits'.

3 According to Section 9 of the Constitution, the laws of Papua New Guinea include, in order of superiority, the Constitution, the Organic Laws, Acts of Parliament, emergency regulations, provincial laws, laws made under the Constitution, and 'the underlying law'. Under Schedule 2 of the Constitution pre-independence laws were adopted as Acts of Parliament at independence. Schedule 2 also defines 'the underlying law' as including both Papua New Guinea custom and the principles and rules of common law and equity in England' as they existed immediately before independence (see Nonggorr 1995). 
4 The word 'own', in turn, is defined by the Oxford English Dictionary as 'have as property, possess'.

5 Sherman and Bently (1999:52) noted that '...expression was thought to carry with it a number of characteristics which provided the means by which the conflicting tasks the law had set for itself were accomplished. On the one hand, expression was abstract and isomorphic enough for it to be reproducible and repeatable. At the same time, the expressive contribution of the author, as well as that of the inventor, engraver and designer, was such that it always enabled the property to be identified.' Over time, however, it became clear that definitions of intellectual property in terms of how ideas were expressed was unsatisfactory. Sherman and Bently (1999:54-5) argued that many contemporary intellectual property controversies (for example, regarding computer programs) turn on precisely the 'twin demands' of being able both to identify property and to protect authors and inventors from competitors who would slightly modify their texts or designs and then claim them to be distinct.

6 Sherman and Bently (1999:18) described the process through which these categories emerged in the following terms: '...just as we see the opening up of a general space for mental labour we also witness changes that would help to set the limits of the general category and, in turn, play a role in shaping the categories of modem intellectual property. Typically, these moves were a by-product of attempts to have new forms of subject matter protected by the law. Rather than focusing upon the general category of mental labour, attention was placed on a specific area of mental labour: on those forms of mental labour which had already been granted property protection. This was because when a case was made for extending property protection to a new subject matter it was usually done by drawing an analogy with pre-existing modes of protection. More specifically, this was done by showing that the new subject matter shared similar features with the subject matter that had already been given protection. As such, the task for those arguing for protection was to find a common link between the forms of mental labour which had already been given property status and the particular case in hand. In these circumstances it thus became important not only to be able to identify how and where the boundaries of the pre-existing forms of protection were drawn, but also to be in a position to extrapolate from the pre-existing regimes in which property rights were granted.' 
7 There is no single history of ideas concerning intellectual property even in Europe. Instead, the extension of property rights to intangibles took different forms in different countries as a result of social, political, and economic differences. French copyright law, for example, emphasises the rights of the author or creator, while US copyright law echoes the Statute of Anne and places public interest on the same level or even above the rights of the author (Ginsburg 1997:79). Similarly, in discussing international differences in the legal treatment of intellectual property, Long and D'Amato (1997:7) noted that, '...the impact of language cannot be minimised. For example, among the issues which has [sic] been the subject of heated debate in the international community is the scope of rights granted an author for the act of creation. These rights, premised on the value added to the work by the unique personality of the human creator, differ from the rights granted under a nation's copyright laws. They generally include the rights of patrimony (or attribution), integrity, withdrawal and disclosure. In France the concept is referred to as 'droit moral,' in Germany, 'urheberspersonlichkeitsrecht,' in the United States 'moral rights or inherent rights.' Similarly, while the US uses the term 'copyright,' France uses the phrase 'droit d'auteur' (or 'droits de l'auteur') and Germany uses the term 'urheberrecht' to refer to a creator's right to control the reproduction and dissemination of her works. Although these phrases are rough equivalents of one another, such equivalency does not fully reflect the differing philosophical and legal precepts represented by the original, untranslated phrases.'

8 The rights protected under the Rome Convention are often called 'neighbouring rights' because they are close to the rights protected under copyright.

9 Article 6bis of the Berne Convention still applies to signatories of that Convention. The exclusion of moral rights from the TRIPs Agreement was justified on the grounds that they are not trade related, and the effect of the exclusion is that disputes over moral rights cannot be settled through the WTO. At the same time, some countries saw the exclusion of moral rights as a victory of the AngloAmerican copyright system over systems that emphasise the moral rights of authors (Gervais 1998:73).

10 Sui generis systems are those developed for a particular application, such as plant variety laws. 
11 Exchange, as we use it here, refers to the transfer of things between social persons. The persons making an exchange may act individually or collectively, and the objects transferred may be tangible (for example, pigs, shells, axe blades) or intangible (for example, stories, artistic designs, rituals). While exchange in this broad sense is part of social life in all societies, it has been a particularly prominent concept in discussions of Papua New Guinea societies where exchange is often fundamental to social relations (Carrier 1996).

12 The identification of gifts as a distinct type of economic transaction can be traced to the French sociologist Marcel Mauss whose 1925 Essai sur le Don (usually translated as 'The Gift') laid the foundation for the distinction between gifts and commodities.

13 Cf. Nicholas Thomas's (1991) critique of the distinction between gifts and commodities in relation to objects in the Pacific.

14 Harrison (1992) referred to 'Western intellectual property law' as though it is a single tradition. As discussed earlier, however, the legal treatment of intellectual property varies somewhat between Western legal systems.

15 Custom is also not adopted if a custom is 'repugnant to the general principles of humanity'. According to Nonggorr (1975:73), this repugnance test, which originated in British colonies in Africa, was used by colonial governments in what is now Papua New Guinea to suppress local customs and institutions. An Underlying Law Bill prepared by the Law Reform Commission in 1976 proposed to remove this qualification. The repugnance test is not required for the application of common law.

16 Customary land, which includes more than 99 per cent of land in Papua New Guinea, is governed exclusively by customary law with disputes being settled through mediation or in Local Land Courts and District Land Courts (Nonggorr 1995:75-6). 


\section{2 \\ Intellectual property rights in Papua New Guinea}

\section{Leslie Harroun}

Intellectual property refers to the products, processes or discoveries that result from the human intellect. Examples include: inventions, works of art, computer software, medical technologies, musical compositions, geographical indications, engineering devices, plant varieties and soft drinks. Intellectual property laws give the originators of such products, processes or discoveries a limited private property right in the fruit of their labour. These rights are granted by governments. Intellectual property shares many of the characteristics associated with real and personal property-it can be owned, bought, sold, licensed, exchanged or given away. The only difference is that intellectual property is intangible; it cannot be defined or identified by physical parameters. Nonetheless, it must be expressed in some discernible way to be protected.

When a government grants an inventor an intellectual property right, it is rewarding that person for his or her creativity and encouraging them to disclose their new information to others through commercialisation. The sharing of information leads to the development of useful new technologies. Without the benefit of legal protection that intellectual property rights provide - and the profit that may follow as a result-an inventor may not be willing to share his or her product for fear it will be stolen or misused to benefit others. When this happens, creativity is stifled.

Intellectual property rights are expensive to obtain and maintain and are usually secured by large corporations who have the resources to develop, establish and protect them. Few individuals hold intellectual 
property rights. Thus, it is unlikely that intellectual property right regimes can provide the same benefits to developing countries that they do to industrial countries where large corporations have substantial resources to invest in technology development.

This chapter summarises the different classifications of intellectual property, what they protect and how, and their usefulness to Papua New Guinea today.

\section{The rationale for intellectual property rights}

Formal intellectual property rights provide an incentive for innovation and the public disclosure of new information. These are essential elements for the development and dissemination of valuable new technologies, including those related to medicine, agriculture and science. People who share the fruits of their labour with society are thought to be deserving of economic reward, granted by the state on behalf of society.

By providing economic rewards, intellectual property rights promote creativity and the sharing of information in a number of related ways. First, they reward people who create commercial or cultural value. Giving the originators of innovations or discovery an exclusive right to market or make a profit from their work encourages creative endeavour.

Second, intellectual property rights allow people to own the fruit of their labour. If something novel and beneficial is produced, society may decide to reward the innovator with some form of ownership of his or her creation. Although this takes the invention out of the public domain and increases its price to others, it encourages people to be creative by placing a value on their effort and providing them with a return for their labour.

Third, by satisfying the principles of moral or natural rights, intellectual property rights can give artists, inventors, traditional healers with biodiversity knowledge and other creative people a sense of parenthood toward their work or knowledge. This connection cannot be protected by traditional property rights because it is intangible. Yet, society can support this relationship by protecting it as intellectual property, thereby restricting the unauthorised use or destruction of useful inventions and knowledge.

Finally, intellectual property rights facilitate the acquisition and development of technology. The development and dissemination of new technologies is expensive and requires investment. Intellectual property 
rights encourage the development of new technology by offering investors a way to obtain financial returns. This has particular relevance in Papua New Guinea where the high genetic diversity is valuable because it can result in the development of new medicines and crops. If an investment in Papua New Guinea's genetic resources leads to a new medicine which is then protected as intellectual property, Papua New Guinea could benefit from any profits made by the medicine, as well as from the medicine itself. Without intellectual property laws, the inventor of the medicine may choose not to export the medicine to Papua New Guinea because his or her ownership interest therein would not be protected there (Gollin and Laird 1996).

\section{The classification of intellectual property rights}

There are five general categories of intellectual property in EuroAmerican law - trade secrets, patents, plant breeder rights, copyrights and trademarks. Each reflects the laws of the country in which it is enacted. Rights established in one country may not be protected or even recognised in another. Similarly, intellectual property laws are not extraterritorial; they do not automatically apply outside the country in which they are law. Despite existing agreements that attempt to harmonise intellectual property laws throughout the world, substantive differences exist, especially in laws governing patentable subject matter.

Although there is no universal agreement on the legal rights that accrue under each type of intellectual property, most countries generally recognise at least those that protect innovative products or processes and those that protect the unique expression of ideas.

\section{Protection of innovative products and processes}

Ideas, knowledge and know-how behind innovative products, processes and discoveries can be protected using trade secrets, patents and plant breeder rights. These types of rights give owners various rights of control over the use of their invention or discovery by others.

\section{Trade secrets}

Trade secrets are used to retain control over, and to prevent the disclosure of, an original invention or process. They protect confidential information and methods that give their owner a competitive advantage. Trade secrets have the potential to protect traditional 
knowledge of a medicinal plant, an extraction method handed down over generations or even taxonomic and ecological information and biological inventories (Gollin 1993). In order to be protected as a trade secret, an originator's information must

- be secret, in the sense that it is not generally known or accessible to persons who normally deal with that kind of information

- have commercial value because it is secret

- be kept secret through the use of reasonable steps taken by the person lawfully in control of the information.

Because trade secrets require both secrecy and evidence of efforts to maintain that secrecy (such as keeping a recipe locked in a safe), they are difficult to establish, protect and enforce. Trade secrets last as long as the information remains unknown. They may be licensed, disclosed or assigned by their owner, but anyone who uses a trade secret without permission and to their own advantage may be liable to its originator for any resulting profits. If the information is discovered by disclosure (by the originator), by independent discovery, accidentally, or by reverse engineering the trade secret is permanently extinguished.

A considerable amount of indigenous peoples' knowledge may be protected by trade secrets, as long as the information has commercial value and provides a competitive advantage. Even if landowners do not wish to commercialise exclusive information themselves, they may restrict access to their land and exchange the information with outsiders only under confidentiality agreements to obtain economic benefit for their knowledge (Posey and Dutfield 1996). Papua New Guinea has no legislation governing trade secrets, although common law received from the United Kingdom at Independence may apply (Nonggorr 1990).

\section{Patents}

A patent gives an originator the right to exclude others from making, using or selling his or her product, process or discovery, usually for ten and twenty years. In order to be protected by a patent, an invention must exhibit several characteristics.

- Specific utility -it must be a useful product or process. Knowledge itself, including ideas, theories and scientific formulas, is not patentable.

- Novelty - the invention must be recent and original and cannot have been previously known, used, made, patented, described in print or in a previously filed patent anywhere. In most countries (except the 
United States) the first person to apply for a patent receives it, whether or not she or he is the inventor.

- Non-obviousness or inventiveness-even if an invention is novel, it may not be patented if its discovery amounts to an apparent or obvious outcome of the prior art (previously known skill) in the subject matter or field. Mere discoveries are not patentable. The invention must be disclosed in a manner so detailed that it would allow a skilled technician to make or use it. A patent for an invented process may cover a non-obvious way of making something already invented or discovered. Similarly, a patent for an invented product does not require that it be made by a novel method.

Patents are commonly regarded as providing superior protection to trade secrets because inventors of patentable products or processes disclose their inventions so that others may learn from them, and because inventors do not have to expend effort to protect their knowledge from use by others. While this may be true in industrial countries, trade secrets are easier to obtain, protect more indigenous knowledge and are less expensive to enforce by individuals or communities with few financial resources. In addition, patent protection does not last forever; once a patent expires the owner loses his or her exclusive rights.

Countries differ widely in the patent protection they offer for living material. For example, in the United States novel genes, DNA sequences, plant parts or varieties and biotechnological processes may receive patent protection if they meet the above requirements. On the other hand, many developing countries exempt medicines, biological processes and products and agricultural technologies entirely from their patent regimes. ${ }^{1}$ One reason for this is to ensure public access to important inventions. However, such a restriction may prompt a foreign inventor not to export his or her technology to any country without patent protection, thereby reducing a developing country's access to that technology. In this situation, the developing country loses twice. While the diverse genetic resources of developing countries are exploited for biotechnology development - often with little financial gain-it is also the case that new technologies do not return to the country due to the lack of patent protection. In this way, lack of patent protection can severely limit the value of natural product development to a developing country (Axt et al. 1993). ${ }^{2}$

Some countries exempt biological processes from patent protection because they fear that a patent on a novel microbe, plant, cell line or purified compound will preclude people from using existing species or 
practicing traditional methods of medicine or agriculture. This is not true. While a patent may remove a novel species from the public domain, the wild species from which it was created remains available for use by everyone (Gollin 1993). Papua New Guinea has no legislation governing patents.

\section{Patents and indigenous knowledge}

Patents cannot be obtained for the discovery of products of nature. Accordingly, wild habitats, species and raw biological materials cannot be patented. As a result, much potentially useful indigenous knowledge about the uses of plants is not patentable because it relies on the properties inherent in naturally occurring organisms. However, products or processes resulting from the development of biodiversity are patentable in some countries. Some inventive preparations of natural substances may be sufficiently novel to be patented, and the patent would provide protection for the knowledge as long as the individual or group applying for the patent can be cited as the inventor (Posey and Dutfield 1996; Gollin 1993).

Unfortunately, patents are prohibitively expensive to obtain and enforce for most indigenous communities. A patent applicant must pay for the filing, examination and grant, which can amount to more than $A \$ 10,000-A \$ 15,000$ for each country in which the patent is registered (Whimp 1997a). Even if a community were to obtain a patent, it would be difficult to enforce. First, they would have to have knowledge of a violation by an outside individual, group or corporation, and then they would have to bring legal action against the infringer. Finding effective legal support and the financial resources to do so would be a considerable hardship for most indigenous people.

Many pharmaceutical companies have investigated potentially useful attributes of plants used for medicinal purposes by traditional communities. In some cases, they have patented an isolated active principle of a biological substance and used it commercially. Although a patent cannot be obtained for a naturally occurring organism, a new synthetic compound based on it, which may be more stable or less toxic than the original substance, may be patentable (Posey and Dutfield 1996).

In cases where a corporation uses indigenous knowledge to identify a useful substance without providing benefits, the local community can contest the patent. The community must show that the invention is 
based on information acquired from the group and was used without their permission. In most countries, patent applications are available to the public before the patent is awarded. The mere threat of a challenge to a patent application is often enough to make corporations more willing to compensate indigenous communities for their knowledge.

An indigenous inventor may also publish a detailed description of how to make an invention, which then becomes part of the prior art that the patent office is obliged to search before awarding a patent. This is called defensive publication and can be used to prevent outsiders from patenting inventions derived from indigenous knowledge or resources. The problem is that the original inventor would have to isolate the active ingredient of the invention and publish the details. Publication may also attract companies interested in exploiting a new product, without necessarily compensating the originator (Posey and Dutfield 1996).

\section{Petty patents}

Petty patents are similar to regular patents (otherwise known as utility patents) except qualification does not require the same level of inventiveness or non-obviousness. For example, a method for extracting a useful chemical from a plant in the Highlands of Papua New Guinea may be obvious given the international state of the art, but it may also be novel, useful and one step ahead of other methods. Petty patents are also less expensive to obtain because the patent examination process is either deferred or replaced by a registration system (Posey and Dutfield 1996).

Petty patents are designed to reward and provide incentive for less sophisticated inventions or discoveries. As a result, it may be easier to protect indigenous rights to biodiversity knowledge with a petty patent system. Petty patents typically last for seven to ten years.

Unfortunately, petty patents are only recognised within the country in which they are law; as yet there are no international agreements that recognise reciprocal rights to petty patents. One alternative for developing countries is to lower the standard of inventiveness for a utility patent in order to protect minor advances in technology and receive international recognition. However, though this may help protect traditional knowledge and local biodiversity, it may also open the door to substandard patents and remove useful products from the public domain (Gollin 1993). 


\section{Plant breeder rights}

Most countries exclude living organisms from patent protection. Plant breeder rights allow exclusion from producing or selling propagating material of new plant varieties for a period of 15 to 30 years. Under the 1961 international convention of the Union for the Protection of New Varieties of Plants, a breeder ${ }^{3}$ may earn the exclusive right to a novel plant variety if it is

- distinctive-distinguishable from other commonly known varieties by one or more characteristics

- uniform-homogeneous with regard to its sexual reproduction or vegetative propagation

- stable-remains true to its description after repeated reproduction and propagation

- novel-not sold or marketed with the permission of the breeder in the source country, or for longer than four years in any other country (Posey and Dutfield 1996).

Unlike patents, plant breeder rights allow the use of a protected variety for creating new varieties, for commercial exploitation and by farmers who wish to use their own harvested material to grow new crops on their own farms. For example, a farmer who purchased a protected plant variety could sell his or her crops commercially and plant new crops with the seeds produced from his or her harvest, but would be prohibited from selling the protected plant or its seeds. From this perspective, plant breeder rights are weaker than patents and would add little value to cultivars that come from wild habitats (Gollin and Laird 1996; Gollin 1993).

Plant breeder rights establish strict requirements for breeding. A new variety bred from a wild plant would normally require several generations of breeding before becoming eligible for protection. In addition, plant breeder rights require financial resources, legal experience and scientific facilities to carry out field trials, record results and otherwise demonstrate eligibility. As a result, it has been more common for professional breeders than traditional farmer-breeders, to take advantage of these rights. This, and the fact that the Union for the Protection of New Varieties of Plants Convention has few member states, means that plant breeder rights have little relevance worldwide. Papua New Guinea does not have plant breeder rights legislation. 


\section{Protection for the expression of ideas}

Some types of intellectual property rights protect the unique expression of ideas, symbols or devices rather than the ideas themselves. There is no exclusion of the right to use the ideas, but they may not be copied in their original form without authorisation. Copyright, trademarks and certification marks are the main examples of this type of intellectual property right.

\section{Copyright}

Copyright laws protect original works of authorship against copying. They cover literary works, dramatic and musical works, works of applied arts and crafts, maps and technical drawings, photographs, motion pictures and sound recordings, computer programs, compilations of genetic data and information in databases. These works must be published in a tangible form (oral information is not protected unless a recording is made). Protection typically lasts 50 years beyond the life of the author.

Copyright protection only covers the author's particular expression of his or her work in a tangible medium. Protection does not extend to the idea, procedure, process, system, method of operation, concept, principle or discovery, regardless of the form in which it is described, explained or embodied. For example, it would not be a copyright infringement to reorganise data from a number of sources into a new compilation, but it probably would be an infringement to copy a compilation outright. Copyright owners have a legal right to prevent others from reproducing their work, performing their work in public, making a recording of their work and broadcasting, translating or adapting their work.

Copyright protection in Papua New Guinea could be used to stop people from copying traditional arts, crafts, songs, designs and other cultural symbols without permission and acknowledgment of the source, or from passing off replicas of indigenous art as genuine. Copyright protection would not protect folklore that is passed on orally from generation to generation, and would only protect written or recorded folklore for a limited time period.

Similarly, copyright is not overly useful for protecting genetic resources. Data collected about species may be subject to copyright 
protection when included in publications or databases, but trade secrets, patents and plant breeder rights are more appropriate than copyright for protecting the genetic resources themselves. Copyright is assigned to individuals or companies, and so would have little use in protecting the rights of a community or clan.

Papua New Guinea passed copyright legislation in 1978, but it has never been implemented. The Copyright Act specifies that a work is not eligible for copyright unless deposit of the work has been made in terms of the Statutory Deposit Act of 1978. This latter Act was never passed. Depositories had to be identified, to hold all copyrighted works in the country before it could be passed, and the two potential depositoriesthe National Library and the University of Papua New Guinea Librarywere unavailable due to lack of funding and staff.

\section{Trademarks}

Trademarks prevent people from using confusingly similar words, names, symbols or devices in connection with the trade of goods to indicate who made the goods or provided the services and prevent deception and confusion in the marketplace. Trademarks protect the competitive advantage of providing a quality product or service, and ensure that the owners of a trademark obtain the profits associated with their product or service.

A trademark can last forever, but cannot be licensed or assigned apart from the goods or services it represents. Although trademarks do not have to be registered, doing so enables owners to license use and sue infringers. The Madrid Agreement Concerning the International Registration of Trademarks enables owners of trademarks to obtain coverage in multiple countries with a single application. Approximately thirty countries have signed this agreement (Posey and Dutfield 1996).

The artifacts and designs of indigenous peoples in Papua New Guinea are highly prized throughout the international market. Without trademark protection, indigenous people would have no recourse against those who make reproductions of their work and sell them as authentic. Consumers who value authenticity may choose to buy goods with an indigenous trademark even if they are more expensive than imitations. Some trademarks, such as the Body Shop, appeal to the ethical values of 
consumers as well by indicating that the purchase of a particular good supports a specific social or environmental cause. In addition, trademarks may deter potential imitators by threat of legal action.

Papua New Guinea has trademark legislation (Trademarks Act, Chapter 385). Trademarks are registered by the Registrar of Trademarks, who operates from the Investment Promotion Authority.

\section{Certification marks}

Similar to a trademark, a certification mark is attached to goods to indicate a certain quality to consumers. Unlike trademarks, certifications are granted by independent public or private organisations rather than the entity marketing the product or service. Examples include the Good Housekeeping Seal of Approval or sustainable timber certifications.

Individual regions or organisations within Papua New Guinea could certify that particular products, such as carvings authentic to a particular area of the Sepik or coffee grown by local villagers in the Crater Mountain Wildlife Management Area, were obtained in a sustainable manner. Once certified, these products should enjoy a competitive advantage among consumers around the world simply because they are linked to sustainable development and are perceived as green (Gollin 1993).

\section{Which intellectual property rights are suitable for local communities?}

No particular mechanism is ideally suited to collective ownership of traditional knowledge and biological resources. While some mechanisms are more suitable than others, they have all developed in a Western cultural and legal framework and are ill suited to this culturally different context.

\section{International law and intellectual property rights}

There are several international agreements and treaties to which Papua New Guinea is a signatory that require the implementation of intellectual property rights legislation. All are likely to affect the biological and cultural property rights of Papua New Guinea citizens. 


\section{The Convention on Biological Diversity}

In 1992, Papua New Guinea signed the Convention on Biological Diversity. This requires Papua New Guinea to develop plans, programs and policies to conserve and sustainably use its resources, to inventory and monitor national biodiversity, and to promote in situ and ex situ conservation. It also raises issues pertaining to cultural property rights, such as the protection of indigenous knowledge about medicinal resources and ownership rights to plant cultivars.

The Convention on Biological Diversity (Article 15(7)) directs its parties to promote 'the fair and equitable sharing of the benefits arising out of the utilisation of genetic resources,' and to take measures to 'respect, preserve and maintain knowledge, innovations and practices of indigenous and local communities embodying traditional lifestyles relevant for the conservation and sustainable use of biological diversity' (Article $8(j)$ ). In effect, the Convention seeks to promote conservation and sustainable development, and establishes the principle of reciprocity between access to the genetic resources concentrated in developing countries and access to the advanced technologies of the industrial countries. It expects that such measures will include mechanisms to govern prior informed consent, benefit sharing and local community control before access to such resources is provided.

A number of countries have already passed laws which implement the Convention on Biological Diversity. These laws have the following protections in common

- they assert national sovereignty over biological resources within national borders

- they require sample collectors to obtain prior informed consent, the scope of which would be defined via a permitting process

- they require benefit sharing, payment or some other consideration to the government as a condition of obtaining a collection permit.

In addition, many national laws include provisions that (Laird 1995)

- establish a national biodiversity board or administering agency

- require that rights of prior informed consent and benefit sharing extend to local communities

- encourage the transfer of technology

- require the use of contracts or materials transfer agreements for any transfer of genetic materials which contain terms for benefit sharing and technology transfer 
Intellectual property rights in Papua New Guinea

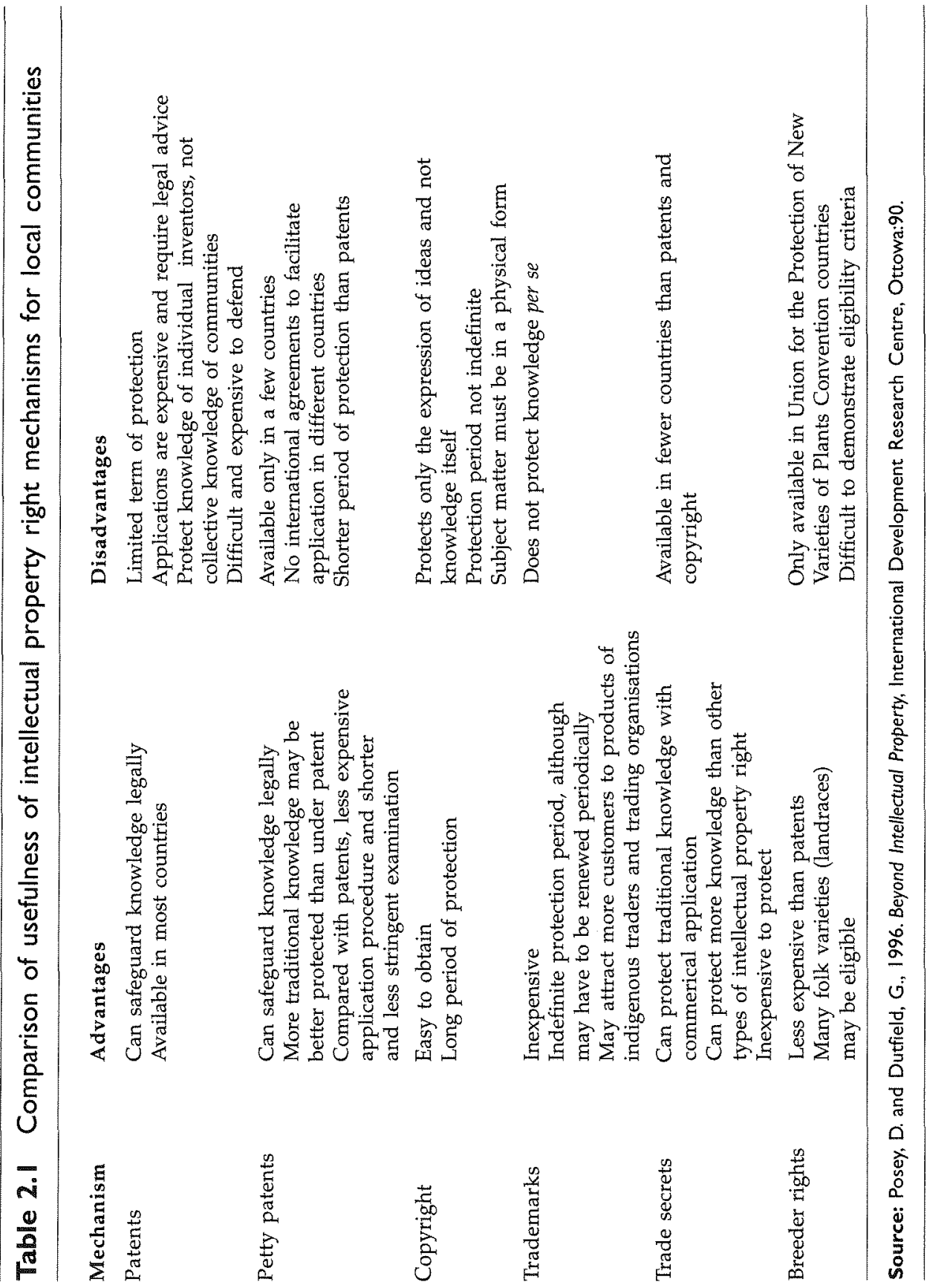


- require that any collection not endanger biological diversity

- require mechanisms to return benefits from exploitation to support the conservation of biological diversity.

The Convention on Biological Diversity provides international legal justification and a framework for Papua New Guinea to establish sovereignty over its genetic resources. It also encourages developing countries to implement intellectual property rights legislation. However, Western intellectual property models may be inappropriate and inadequate for Papua New Guinea at this point in time.

Intellectual property rights presume the desire and ability to commercialise products, processes or discoveries, which most indigenous people and communities do not possess. For many local communities in Papua New Guinea, art, songs, dances and plant knowledge represent more than intellectual property, and concepts of knowledge ownership are profoundly different from those of Western economics and jurisprudence. Traditional systems for sharing and transmitting knowledge and for regulating access to natural resources are extremely varied and most differ greatly from industrial societies.

While the language of the Convention on Biological Diversity and its associated agreements is vague regarding the rights of indigenous peoples, it provides an opportunity to define what those rights will be. As suggested by Posey and Dutfield (1996:104)

Given that indigenous peoples are recognised as having specific rights and benefits and that economic livelihood is linked to development and conservation of natural resources, as much energy and effort as possible should be put into activating the sections relevant to indigenous rights-especially the recognition and protection of, and compensation for, intellectual property. General Agreement on Tariffs and Trade negotiators, FAO, the WTO, and the World Intellectual Property Organisation will all have to accommodate to this reality in future because the vast majority of countries are signatories of the [Convention].

Overall, the Convention on Biological Diversity provides a framework that can help boost Papua New Guinea's negotiating strength in situations involving access to and development of its genetic and biochemical resources. However, Papua New Guinea has yet to incorporate the Convention into domestic policies or legislation. This means that under foreign property rights laws, biological resources still constitute common knowledge and are open to all. Through the Convention on Biological Diversity, Papua New Guinea now has the opportunity to develop the policies and legislation needed to achieve the 
benefits possible through development of its natural and cultural resources.

\section{The Trade-Related Aspects of Intellectual Property Rights}

\section{Agreement}

The Trade-Related Aspects of Intellectual Property Rights Agreement is an international agreement entered into under the framework of the General Agreement on Tariffs and Trade, to which Papua New Guinea is a signatory. It requires Papua New Guinea to meet minimum standards for protecting patents, copyright, trademarks and trade secrets and other related rights within a period of five to ten years.

The Trade-Related Aspects of Intellectual Property Rights Agreement is perhaps the most ambitious multilateral agreement to regulate intellectual property in the world. It incorporates provisions of the Paris Convention, the Berne Convention, and other international intellectual property treaties, and is based on the recognition that failure to provide adequate and effective intellectual property protection is a barrier to legitimate trade. ${ }^{4}$ The Agreement extends national treatment and most favoured nation treatment to countries with intellectual property protection.

The Trade-Related Aspects of Intellectual Property Rights Agreement has been strongly criticised by proponents of indigenous rights. They argue that developing countries are being pressured into accepting protection of plant genetic resources and limitations to access which are contrary to many customary practices of sharing seeds and community innovation. This is particularly true for plant breeder rights, which have the potential to encourage monocultures over in situ conservation and lead to negative implications for biodiversity. Yet within the TradeRelated Aspects of Intellectual Property Rights Agreement there is an opportunity to develop a sui generis (one of a kind) system for the protection of plant varieties that could serve the interests of local communities. In addition, the Trade-Related Aspects of Intellectual Property Rights Agreement excludes plants and animals from patentability, except for microoganisms and biological processes for the production of plants or animals (Article 27.3(b)), and allows countries to prohibit the patenting of commercial inventions that would lead to serious environmental prejudice (Article 27.2). In any event, it is possible under international law for indigenous people to demand that 
governments prohibit multinational corporations from patenting plant and animal material found on their lands.

Countries considering implementation of both the Trade-Related Aspects of Intellectual Property Rights Agreement and the Convention on Biological Diversity should examine how the two sets of laws interact. For example, if Papua New Guinea is interested in promoting natural product development it should consider greater patent protection for biotechnology inventions than the Trade-Related Aspects of Intellectual Property Rights Agreement requires. It should also consider enacting such legislation now rather than waiting the allowed five or ten years.

\section{The World Intellectual Property Organisation}

The World Intellectual Property Organisation, established in 1967, promotes international protection of intellectual property and facilitates international transfers of technology. Papua New Guinea became a member of the World Intellectual Property Organisation in November 1996.

As a United Nations specialised agency, the World Intellectual Property Organisation administers several multilateral intellectual property treaties, including the Paris Convention for the Protection of Industrial Property (1883), the Berne Convention for the Protection of Literary and Artistic Works (1886), the Madrid Agreement Concerning the International Registration of Trademarks (1891), and the Patent Cooperation Treaty (1970). The World Intellectual Property Organisation also provides assistance to signatory nations seeking to enact intellectual property laws and attempts to harmonise national laws throughout the world.

\section{Conclusion}

Intellectual property rights are useful to protect the products, processes and discoveries of human creativity and to encourage technological innovation. They become important when individuals (and corporations) want to make a commercial profit from their innovation or discovery. From this perspective, they protect purely economic interests. They are difficult, time consuming and expensive to obtain. Once secured they often have to be defended. They require elaborate national 
legal and regulatory institutions, including a patent and trademark office, copyright registry and a court system able to handle intellectual property cases. These all require substantial commitments of national funds and expertise.

Most developing countries do not have the resources to obtain or protect these economic rights, and therefore are unable to benefit from them even if recognised as law. In fact, most indigenous people and local communities would be put at a disadvantage relative to multinational corporations and other biodiversity end users if they tried to protect their knowledge and resources by employing these rights. Intellectual property rights are generally inappropriate and ineffective for defending traditional knowledge and resource rights, which are in large part linked to rights of self-determination. Fortunately, a number of alternative strategies for protecting indigenous knowledge and resources are emerging based on sui generis rights and restricted access to traditional cultural and biological resources.

Like most developing countries, Papua New Guinea has tremendous human and natural resources to nurture and promote. As a signatory to the Trade-Related Aspects of Intellectual Property Rights Agreement, the World Intellectual Property Organisation and the Convention on Biological Diversity, Papua New Guinea must make some immediate decisions about what types of intellectual property rights it wishes to embrace. It must think carefully about the impacts of each intellectual property right regime on economic policy, technology transfer, indigenous rights and biological diversity. It must make sure that its objectives are clearly incorporated into legislation and that they clearly address sources of conflict among these conventions. Papua New Guinea is a unique country and has the ability to define its own future-using intellectual property rights and sui generis rights wisely and creatively can help Papua New Guinea realise its future. 


\section{Notes}

1 A number of countries do not allow patents for pharmaceutical compounds or compositions: Argentina, Brazil, Egypt, Ghana, Honduras, Hungary, India, Iran, Iraq, Kuwait, Lebanon, Libya, Monaco, Norway, Poland, Portugal, Syria, Tangier Zone, Thailand, Tunisia and Turkey. Even more countries restrict patents for biotechnological processes and products: Brazil, Chile, Colombia, Denmark, European Patent Office, Finland, Great Britain, Hungary, India, Kuwait, Lebanon, Malaysia, Mexico, Nigeria, Peru, Romania, South Africa, South Korea, Spain, Taiwan, Thailand, Tunisia, Turkey, Uruguay and Yugoslavia (Gollin 1993, citing Baxter and Sinnot 1992).

2 Some people argue that the privatisation of the biotechnology industry and the recognition of property rights in biotechnology hinder access to these technologies by developing countries, who most need the benefits, presumably by making the cost of such technology exorbitant. For this reason, it is sometimes argued that intellectual property laws are irrelevant or even detrimental for developing countries (Dembo et al. 1985:431, 444 (note 62), 450-2).

3 Under the 1991 revision of the Union for the Protection of New Varieties of Plants, a breeder is a person who breeds, discovers or develops new crop varieties.

4 The Paris Convention for the Protection of Industrial Property (1883) directs that signatories must accord foreign patent and trademark applicants and owners the same treatment and rights as domestic patentees, although it does not grant any substantive international intellectual property rights. The Berne Convention for the Protection of Literary and Artistic Works (1886) establishes international standards for copyright protection. Member nations must provide protection for all copyrighted material, with minimal requirements for notice and registration, making copyright the simplest universal intellectual property rights system in the world. Papua New Guinea is not a signatory to either of these conventions, but will be required to adopt legislation that complies with them in order to meet its obligations as a member of the World Trade Organisation. 


\section{3 \\ Multiple perspectives on intellectual property}

\section{Marilyn Strathern}

The concept of intellectual property has opened up possibilities for the legal protection of rights to intangible resources, including the products of knowledge and other forms of creativity. It has thus become one possible route to recognising the holders of the 'knowledge, innovations and practices of indigenous and local communities embodying traditional lifestyles relevant for the conservation of and sustainable use of biological diversity' (Convention on Biological Diversity, Article 8(j)). The Convention leaves it open as to how signatory nations are to respond but cautions them over intellectual property rights agreements lest these run counter to rather than support its objectives (Article 16.5).

Intellectual property has suddenly become a topic of widespread international interest. Moreover, once articulated, it rapidly catches the public imagination, and this is something to be taken into account in policy development. What makes it such a powerful and debatable topic? The first part of this chapter suggests it is important to understand the Euro-American culture which has produced the intellectual property concept as well the cultures which may adopt it. Assumptions and practices originating from northern Europe and North America inform many values that the international community takes for granted. Less obvious is the fact that these include some of the ways in which not just support of but opposition to intellectual property rights has been expressed. Further, Euro-American culture, like any other, is constantly changing, and stereotypes get out of step with current social realities. These offer points for debate in the second part of the chapter. 
One approach to weighing up the advantages and disadvantages of intellectual property rights is contained in the very notion of property. At the heart of Euro-American ideas lies a creative ambiguity: on the one hand property refers to things and on the other hand to social relations (Hann 1997). Things may or may not be tangible; property is equally the thing in which a person holds rights and those rights themselves. In the second sense, property points to a set of relations between persons with respect to a thing, for claims are always made by persons in relation to others and within a field of relationships which recognise those claims. Thus the Convention on Biological Diversity has created a new arena in which rights may be negotiated. These terms (things and relations) are useful more generally as points of entry into the debate. As the Papua New Guinean material shows, however, they are useful only up to a point, and the third part of the chapter touches briefly on Papua New Guinean concepts of property.

\section{Intellectual property rights: global resources and protection for people}

Intellectual property rights cannot be ignored as a tool in international law, but why are intellectual property rights a global issue? What public expectations do they raise? The hope for new raw materials, the thought of new ways to gain from old ones, and perhaps even the idea that if one lost out in earlier distributions of resources, here one can be in at the beginning, and the recognition of diverse actors in the field all play their part. $^{1}$

\section{New things: new products}

Competition is one impetus to create new economic products. Resource hunting by companies for usable products and new uses leads to the discovery of new materials (things) to which economic value can be attached; biotechnology companies may rate success in terms of numbers of patents. This contributes to the pace of technological innovations in the industrialised world, and the commercial expectation that anything exploitable should be exploited alerts people to hitherto unseen possibilities.

New inventions lead to value being put on both the inventive capacity itself and the knowledge behind it. Intellectual property rights encourage inventors to spread their knowledge (rather than keeping it 
secret) once they have secured recognition. Intellectual property rights can thus be applied to things still in the making - it is possible to patent a manufacturing process as well as a product, and that may come to cover uses as yet unanticipated. In pointing to future economic potential, it appeals to the imagination. In effect it invites people to ask how they can put their knowledge to future use. 'Prospecting' of all kinds is characterised by a high degree of awareness that change signals more change. Provision is made for the uncertainty of what will be an asset in the future. Many things hold potential. The question behind patenting-whose knowledge was put to use?-alerts people to putting value on what might be useful.

New ways of thinking about existing products emerge. Value put on knowledge as a resource and on the acknowledgment of creativity in authorship leads to reflection on knowledge already made useful, and thus already embedded in artifacts (design), persons (in the form of intention ${ }^{2}$ and transferable skills) and practices (medical remedies). Such knowledge (for example, ethnobotanical classifications) may be an aid to future discoveries or, in coming to be valued in its own right, evokes what is already in place. The general idea of cultural property as embedded knowledge is a prime example. The question behind copyright-who is the original author?-raises expectations about assigning property rights to all kinds of products attributable to past human creativity.

\section{New relations: new social actors}

The widespread consensus that economic growth is key to the survival of political institutions such as the state underwrites agreements endorsing national sovereignties. Nation states are not new, but the kinds of relations that state agencies have with aboriginal peoples ('first nations') as well as with transnational corporations are being constantly refashioned. Intellectual property rights flourish in a social context energised by the relationship of national innovation to globalisationwill national interests get increasingly competitive or dissolve in the face of multinational and other conglomerates? The phenomenon of interlinked economies shows persistent national differences as the driving force behind the globalisation of technology (Bartholomew 1997). ${ }^{3}$ The expectation that national interests are people's interests is written into many inter(trans)national agreements.

Agreement that the protection of property rights is an issue of worldwide concern is embedded in organisations (such as non govern- 
ment organisations) and social instruments beyond the state. The former disseminate information and thus act as knowledge brokers across national boundaries. The latter include ways of dealing with access to and protection of resources beyond an exclusively national perspective, including soft law regulations. ${ }^{4}$ They create expectations both of free movement (for example, knowledge of what other groups are doing) and of regulation (international agreements) beyond the state.

Acknowledgment that human rights make it necessary to single out categories such as indigenous peoples and women assists the formalisation of interest groups. ${ }^{5}$ This has created unprecedented possibilities for enfranchising local interests through a global identity (indigenous groups may or may not be coterminous with the nation).

Expectations of intellectual property rights are played out in advocacy and opposition. Both enthusiasm for and criticism of intellectual property rights touch equally on property thought of as a thing and property thought of as rights between persons with respect to a thing.

\section{Enthusiasm for intellectual property rights: advocacy}

Things. Intellectual property rights are seen as a legal instrument that will allow indigenous communities to assert claims on the international stage in a manner hardly yet possible. ${ }^{6}$ The very idea of intellectual property lends itself to all kinds of creativity. What helps technology also helps indigenous activists who have in the past struggled for a voice

Indigenous knowledge, historically scorned by the world of industrial societies, has now become intensely, commercially attractive... At bottom, intellectual property rights consist of efforts to assert access to, and control over, cultural knowledge and to things produced through its application. [Among those who] seek equity for the world's indigenous peoples the thought arises, why couldn't indigenous peoples own their cultural knowledge, and then, if they allow it to be used elsewhere, secure a just share of the money it generates (Greaves 1994: ix, 4).

Relations. Intellectual property rights are premised on a sense of equity, the two-way flow of knowledge and recompense. They do not just create a legal arena to protect rights, they give power to new social actors, that is, the legal 'person' identified as inventor or author in whom the property rights are invested. Such persons are legally individuals ('juridical persons'), a concept which can include corporate bodies such as government agencies or research institutes. Any social unitindividual, clan or village-could theoretically seek registration as a juridical person and thus as a potential right holder. 


\section{Criticism of intellectual property rights: opposition}

Things. Not everything can be considered as a thing to be owned, for in Euro-American thinking, ownership implies the right of alienation (disposing of the thing to another, for example, through sale or as a gift). The question of what can and cannot be alienated is often answered in terms of the kind of thing at issue. Thus many Euro-Americans regard nature as a common resource for humankind that should not be allocated to specific owners. The question then focuses on exactly what nature is.

When the European Parliament in July 1997 debated a directive for the legal protection of biotechnological inventions to give companies the right to patent organisms created through microbiological processes, one opponent referred to this as 'a charter to enslave nature'. Organisms are not appropriately owned in this thinking, nor is 'life'. This comes from a Euro-American preoccupation with things as objects of manipulation; any entity that is a person (subject) or of human material or simply animate may be protected from object-like status. It also comes from the idea of nature as a resource to be freely shared. To assert property rights is to diminish the commons (resources from which no one is by right excluded).

Social relations. The question of what can and cannot be alienated is answered in terms of people's relationships with one another.

Opponents of intellectual property rights may see them as asserting a form of private property that challenges the ethos of sharing that they would attribute to collective ownership typical of indigenous communities. Generations of people are responsible for building up cultural knowledge. Not to acknowledge this is to deny people's cultural and inalienable heritage.

Contemporary intellectual property law is constructed around the notion of the author as an individual, solitary and original creator... Those who do not fit this mode-custodians of tribal culture and medical knowledge, collectives practising traditional artistic and musical forms, or peasant cultivators of valuable seed varieties-are denied intellectual property protection. For members of indigenous peoples, knowledge and determination of the use of resources are collective and intergenerational (Bellagio and COICA statements, Posey 1996b:13).

Intellectual property rights seem a poor social register and may even set people against one another. If the identification of individual authors or inventors becomes problematic in light of traditional authorship and collective inventions, then the identification of individual property 
holders becomes problematic in the light of multiple claims. Even if a group can be identified, who belongs to the group? Who is the representative to speak on its behalf? What about power inequalities between different interests within the group?

\section{Points for debate}

Intellectual property rights are derived from Euro-American culture. Euro-American critics themselves emphasise this, and seize on individualism and private property as the principal problems. Some evoke an older European vocabulary through appeal to community and practices of sharing in the free transmission of knowledge. This vocabulary seems to mesh well with similar criticisms that come from communities proclaiming traditional rights or different kinds of relations with nature. One might conclude that these criticisms indicate how to put indigenous culture on the map. ${ }^{8}$ If Papua New Guinea is to identify itself with indigenous and traditional values, then it might already have the tools for a Papua New Guinea response. But perhaps the conclusion is premature, for it does not follow that current criticisms of intellectual property rights automatically indicate a Papua New Guinea way. Debate about these issues should question the assumptions behind the way intellectual property rights are opposed, as well as those by which it is supported.

Euro-American ambiguity towards property (see the Annex at the end of this chapter) fuels both enthusiasm and antagonism towards intellectual property rights. Attacks on individualistic notions of property echo the kinds of criticism Euro-Americans make of their own practices. For 300 years they have railed against the individualistic connotations of property, and drawn on their own ideas of its opposite (communal forms of ownership) in order to do so. In the case of intellectual property, nineteenth century protesters resisted the idea that knowledge can be treated as property. This was regarded in Europe as both a practical and moral matter. The flow of ideas could not be controlled, but equally importantly, ideas are in essence free goods and, therefore, common property' (Brush 1993:655). Common property is equated not with collective identity but with unrestricted access.

Much critique was directed towards property as private and exclusive ownership, though one should note that the concept of property as a bundle of rights always allowed the recognition of multiple rights. One alternative to intellectual property rights which has received support 
from several quarters-traditional resource rights-adopts the bundle of rights idea (Posey 1996b; Posey and Dutfield 1996). This argues that resources can be best protected through recognising the diverse, overlapping principles embodied in multiple instruments and agreements that reflect whole bundles of different rights (for example, the right to self-determination, cultural heritage rights and the right to privacy), of which intellectual property rights form only one.

In the late twentieth century, Euro-American culture fuels the way in which much of the international community approaches both the exploitation of resources and the remedies to this. It provides both the language for the notion of intellectual property and a language for resistance. Across the world bodies have debated the utility of intellectual property rights in terms of the kinds of communal rights that should be asserted against those of individual ownership and the extent to which commodification (making things marketable) undermines the free sharing of resources. Euro-American assumptions about authorship and individuality have been attacked, and one welcomes the new international consensus that points to other ways of defining rights, notably the idea of collective rights. But does the model of collective rights have to be that of communal rights, and does the counterpoint to commodity have to be the sharing of resources?

This is not just an academic matter; there is a real need for a contemporary view. First, the things over which companies and nations compete are constantly changing and thus so are the kinds of rights people seek. If genetic material turns into an informational resource which can be used over and again without diminution (like a performance), its new character creates new problems and possibilities for asserting property rights (Parry 1997)-how do you keep track of multiple transactions?

Second, social realities are changing all the time, and stereotypes get out of date. It would be a mistake to stereotype all commercial firms as monolithic capitalist enterprises like armies out to occupy new terrains. For many, a better analogy would be the flexible and adaptable guerrilla who would seize opportunities but not wait around for them; whose dependence on raw materials may be no more than an initial step in a long process; who would be able to transform products to the extent that the original creators are left far behind. An exaggeration perhaps, but international organisations in technology development (where intellectual property rights remain significant) operate at diverse levels, 
for example, integrating basic and applied research between firms and research institutions. Companies do not just act as competitive individuals. Knowledge transfer becomes a new item of transaction, and alliances are established and communication networks are created. ${ }^{9}$

In sum, it would be a pity if particular Euro-American views of community and sharing led to definitions of practices that do not in the long run help in dealing with outside interests. These views pose their own problems - what might sound well in international debate may create unanswerable internal questions (including those concerned with what a community is and who has the right to share). Finally, we need to look at Papua New Guinea as is, not as defined in advance by the international community. So is there a Papua New Guinea way?

\section{Transactions in Papua New Guinea}

\section{What is property in Papua New Guinea?}

This question could result in a huge matrix depicting all the kinds of things in which people have rights (for example, land, decorations, tankets ${ }^{10}$ and pigs), alongside the relations involved, both the nature of the right (ownership, possession, stewardship or usufruct) and the categories of social person who may be right holders (chief, clan, sister or individual). Within the matrix, one would find rights to intangibles as the product of intellectual or creative effort-magical spells, habits purchased from seniors, rights of entry into grade associations, malanggan designs (where it is not the figures but the images that circulate), as well as myth, songs sung on particular occasions and ritual styles (Harrison 1992). But there are many songs, styles, and indeed, whole areas of knowledge that one would not consider property in the same way. And there are many ways in which persons exercised rights in relation to one another that one would not necessarily wish to call property rights. What is the difference?

Some would say the question is pointless. In this view the very idea of property seems inappropriate to the Papua New Guinea situationeverything is implicated in everything else, and property simply distorts the holistic nature of indigenous realities. Although there is truth to this view, there would be some use in developing a counterpart to the international term 'property'. 
The Papua New Guinea situation throws into relief the limitation of focusing only on things (items in which people have rights) or on relations (how those rights are held between persons). This focus can of course be developed to allow for multiple rights; it can be stretched to accommodate so-called forms of communal property. But it forces attention onto the identity of the things (such as sacred sites and botanical knowledge) or the identity of the social persons claiming rights (the clan as a right holder or the individual who claims usufruct), and moreover onto identity already established (as when people say that long-standing community values are threatened by property claims). A third dimension also demands attention.

\section{Property through transactions?}

Perhaps one answer to the question of what constitutes property in Papua New Guinea is that there is property where there has been a transaction. Papua New Guinean practices introduce the idea that rights may be defined by the process of transaction itself. This perspective would bring Papua New Guinea closer to international understandings of contract. It would also deal with a crucial dimension of Papua New Guinea social reality. Many things (tangible and intangible) are regarded as derived from other persons-creativity or knowledge frequently passes from one person to another, so that a person has rights by virtue of his relations with other persons. This includes the life and/ or body that, in some societies, a mother's brother gives to his sister's children. This does not just mean that a person holds right of possession against other persons or by virtue of courts of law to uphold them. It means that the possession is itself created out of social relationships because the thing in which the rights are exercised embodies that relationship. Euro-Americans may think in similar terms but do not build the kind of social practices out of them that are found in Papua New Guinea. Two sets of practices are relevant here.

The first comes from the familiar case of multiple rights. A right may be invested in the individual but the individual is embedded in relationships. Land holding is a common example. For the case of intellectual products, consider a carved design owned by $\mathrm{X}$ by virtue of the fact that $\mathrm{X}$ belongs to clan $\mathrm{Y}$. The design is also owned by the clan, even though no other clan members may exercise that right on an individual basis till the right holder dies. Alternately the carving may 
have been derived from inspiration inculcated by a master (Kasaipwalova 1975). What typifies such rights is that they are exercised in specific contexts. Often the social relations (for example, clan membership or apprenticeship) are made evident at the same time as the right is. Preexisting identities are not sufficient. If people have the right to perform certain acts, such as mortuary service, this is held in relation to specific others (for example, the deceased's kin), and is realised only in their company on that specific occasion. The right of a mother to eat the bridewealth pig for a daughter may affect none of her claims over pigs until the occasion when that right is mobilised by the relationships brought into play at marriage. The thing produced or the performance enacted embodies relationships-the bridewealth pig is a vehicle for the relationships the mother has with both her daughter and with her in-laws; an artist and his ancestors together produce an image, and the (making of the) image itself incorporates that relationship. However, the extent to which such relationships entail overt 'transactions' varies.

The second, the extent to which rights are defined by having something to dispose, is less familiar outside Papua New Guinea. It may also be the case that within Papua New Guinea it is more salient in some regions than in others. In the Western Highlands the ability to pass something on may be circumscribed (for example, a man may gift a pig where a woman cannot) but nonetheless be a prerogative. The converse is acquisition, where the ability to acquire rests not in the nature of the thing but in the relationship between parties agreeing to the transactability of the item (like contracts). The grounds may be those of recompense (as in exchange or donation), kinship (as in inheritance), learning (as when a junior gains knowledge from a senior), intent (in preparing a garden) or inspiration (as when someone dreams a design). While these are based on prior relationships, the relationships have built into them an expectation of transaction or disposability. One might talk of the right to endow, as when one group of men endows another with a woman in marriage-for the right to endow (so to speak) usually carries the benefit of eliciting a counter-endowment (for example, sister exchange). Claims may or may not be exclusive; in some cases a crucial component of A's acquisition of things is the fact that he or she obtained them from B. There may be a coercive elementtransactions lead to transactions, solicitory gifts to return gifts; plants in the ground belong to the planter but are intended for another who has 
exclusive rights of consumption. The same things are disposable in some situations and not in others. The point is that things may embody relationships as the process of attachment and detachment. Sillitoe (1998) refers to the right of disposal-we might consider this a property relation.

\section{Some corollaries for intellectual property}

Papua New Guinean knowledge and creativity is both embedded and transactable. Perhaps we should be looking for conditions of transaction (not forgetting that exclusion or inclusion-property-may work here as anywhere else). The above leads to much misunderstood practices of reciprocity; reciprocity is entailed precisely because one party involves another. It is not itself inherently virtuous. But it means that there is no simple confrontation between communal versus individual rights-we are dealing with specific interests embedded in relations between persons.

That things reify relations is often misunderstood as mercenary interest. If there is value in transforming human relations into things which can be transacted, does this entail a right (just as the international community transforms relations into documents, often under scrupulously adjudicated circumstances)? This is not just sharing versus commodification. If technological process is criticised (as, for example, in the case of the commodified seed that does not reproduce (Shiva 1992)), what about reproduction through transactions as such? The right to reproduce may entail the right to bestow ('life' and 'body', in the form of things, on future generations).

The idea of relations transactable in things leads to a proliferation of compensation practices (Filer 1997). Opponents of intellectual property rights may claim that one cannot identify the individual author under indigenous regimes where innovations are cumulative, and then attack the whole idea of payment. But payment in Papua New Guinea precisely means making intangibles tangible. The question is what you can and cannot make material. Payment for intellectual property is criticised for imposing the Euro-American split of mind from body, as in the transformation of community economies to market ones. But where there is no division between persons and things, then the practice of eliciting specific knowledge or assets through the payment of things may be a sui generis mode of dealing with relations between persons. Of course it may lend itself to market forms, and to successful or unscrupulous behaviour. Nonetheless there are interesting hints for 
looking at international conventions of contract and further research is needed.

These observations about transactions in Papua New Guinea are somewhat tentative and speculative. They may or may not be useful in the present context. It remains the case, nonetheless, that whatever place intellectual property rights hold in people's imagination and expectations, transactions will play a major part.

If getting instruments in place to divert the Convention on Biological Diversity protocols into local channels is difficult, the potential of compensation as an enabler of a modernised indigenous order promises to burst the banks. Its power lies in the very way in which equivalences are set up between human values (persons and relations) and things. There will be no problem about sweeping into the arena of compensation practices all manner of inventions and innovations. This is not because there is no clear distinction between work and resources or between control over knowledge and rights established through the exertions of those to whom one is related. Rather, the issue is the power of transactions to define interests in resources-for those transactions in turn expand people's capacity for social relationships, whether between the transacting parties or in relation to others, offering both old and new bases for power relations.

There is opportunity for a fresh look at intellectual property rights as at once an enablement and a problem. Many critiques about individualism and commercialism reinvent old sources of EuroAmerican criticism. They are as valuable, and as limited, as the notions of property that they seek to modify. The Papua New Guinea way would be to add richness, complexity and a different kind of realism to both sides of the debate. 


\section{Annex}

\section{Diverse perspectives on Euro-American ideas about property}

Property has carried radically different connotations at different moments in European history (Hann 1997). For example, Roman law, foundational in many continental European countries, identified ownership with the thing owned. Property was capable of infinite division, as in peasant Europe, where landholdings would be divided into smaller and smaller parcels among heirs. Things were thus divided between persons by being split into shares. Title inhered in the thing owned (for example, an estate) to which persons became attached, and only certain things were regarded as property (movable or immovable goods). Communal property comes from the idea of persons held together by common bonds in a piece of property which they share.

Compare common law, as practised in England, following feudal holdings, which rendered the thing indivisible so what was divided was rights among people. Thus things are not divided: rights in them are, and any one thing might have several owners. People could thus buy and sell rights in things without altering the thing itself, a system that allowed intangible entities such as copyright and patents to be regarded as forms of property. Since the right inhered in the individual person, this was also the precursor of private property. Private property entails the right to exclude others, and common property, the individual's right not to be excluded.

Nineteenth century objections to private property (capital) derived from longstanding debates over labour; if people have a right to enjoy the products of their labour, when labour can be bought and sold, what rights has the new 'owner' gained? One response: the wage labourer sells his time, but his person remains free. Counter-response: labour is already defined as on the market; the labourer is not free to dispose of his or her labour otherwise. Models of communal enterprises to which people instead contributed their collective efforts was one solution to this impasse.

Property is tied up with specific political as well as economic systems, for example, protection of individual rights within a state system. What protects one person (claims to the usable products of their activities) may exploit others (disregard for other kinds of claims). It is the doubleedged character of property (protection for this person, exclusion of 
that) that makes it at once a highly moral and highly dubious construct. Throughout modern European history property has been a source of indigenous (European) contest.

Many twentieth century Euro-Americans are concerned about commodification. Part of the above politics has been the human rights insistence that persons should not be treated like property. Property is bound up with social identity, whether corporate (as in attachment to estates) or individual (authorship). It is when it comes to buying and selling that some things are properly regarded as alienable and some as not. A person may have title but still be restricted as to how to dispose of property (including, for example, the restrictions posed by inheritance laws), but the issue of monetary gain adds a further dimension to what are perceived as sometimes acute moral dilemmas. The European Community biotechnology directive led to an outcry at the point when it seemed to be sanctioning the commodification of human material. Embryo research and the 'ownership' of organs and body parts interfere with European notions of 'life'. It is interesting that one solution to thinking about rights in embryos outside the body (created through reproductive technology) has been that of dispositional control-rights in disposal (Robertson 1994).

\section{Notes}

1 Perhaps much activity from former colonial states gains impetus from what are perceived to be past inequities to be rectified rather than from a realistic estimation of current realities. Compare the 'futuristic' connotations of bioprospecting with the whole issue over the protection of food varieties, especially in grain-growing countries (Shiva 1992).

2 American litigation over parental rights in the context of new reproductive technology has, by analogy with intellectual property rights, included attempts to establish a claim through the 'intention' to reproduce.

3 Diversity of national policies and regulations flourishes. Attempts by the European Community in 1997 to harmonise laws of member states relating to biotechnology is a case in point. The United States is particularly typified by increasing protectionist legislation for intellectual assets.

4 Soft law refers to declarations of principles, codes of practice, 
recommendations, guidelines, standards and resolutions. Although such documents are not legally binding, there is a strong expectation that they will be respected by the international community. The evolution of customary international law is accelerated by including customary principles in soft law agreements and non-governmental declarations; these become hardened through worldwide acceptance (Posey and Dutfield 1996:120).

5 Posey and Dutfield (1996) include texts of the Declaration of Principles of the World Council of Indigenous Peoples (1984); UN Draft Declaration on the Rights of Indigenous Peoples (1993); KariOca Declaration and the Indigenous Peoples' Earth Charter (1992); Charter of the Indigenous-Tribal Peoples of the Tropical Forests (1992); the Mataatua Declaration on Cultural and Intellectual Properly Rights of Indigenous Peoples (1993); Recommendations from the Voices of Earth Congress (1993); UNDP Consultation on the Protection and Conservation of Indigenous Knowledge (1995); and UNDP Consultation on Indigenous Peoples' Knowledge and Intellectual Property Rights (1995).

6 But the number of cases where this has happened successfully is small. For example, it would be possible for tribal rights to a folk variety of plant to be asserted through the US Plant Variety Protection Act, although no 'tribe' has to date deployed this mechanism (cited in Brush and Stabinksky 1996).

7 Intellectual property rights began with the early modern state in Europe breaking the monopolies of guilds in giving individual authors rights to the products of their exertions.

8 For example, the Charter of the Indigenous-Tribal Peoples of the Tropical Forests (Article 40) specifies that: 'Programmes related to biodiversity must respect the collective rights of our peoples to cultural and intellectual property'.

9 Small start-up biotechnology firms collaborate with larger firms - the former carry the risk of innovation and offer specialist expertise, while gaining from the latter's access to marketing channels.

10 'Tanket' is a Tok Pisin word referring to a shrub (Taetsia fructicosa) and the leaves of that shrub. Tanket are symbolically important in many parts of Papua New Guinea. 


\section{4 \\ Copyrighting traditional Tolai knowledge?}

\section{Jacob L Simet}

In 1978 the Papua New Guinea Parliament passed the Copyright and Neighbouring Rights Act. However, because of the absence of related depository legislation the Act was never gazetted and so it did not become law. The legislation remained in abeyance for the next twenty years until the subject of copyright re-emerged in 1997 and new legislation began to be discussed. The National Executive Council approved a revised Copyright and Neighbouring Rights Bill in 1999 for presentation to Parliament. At the same time, in anticipation that legislation would be passed in the not too distant future, the PNG government established a National Intellectual Property Rights Committee to administer the new legislation. The Committee is under the auspices of the Investment Promotion Authority. However, by May of 2000 the bill had still not been passed by Parliament.

In the lead-up to the passage of the first Act in 1978, debate was mainly concerned with the economic impact of the legislation and its effect on creativity. Economic concerns included Papua New Guinea's ability to afford copyright fees on imported intellectual property such as books, films and music. Arguments in favour of copyright pointed to the revenue that Papua New Guinea's intellectual property owners were losing because of the lack of copyright protection. In relation to creativity it was argued that Papua New Guinea as a cultural entity was young, so there was a need for a relaxed cultural environment allowing for borrowing and sharing of the products of creative effort. Copyright 
was seen as a stumbling block that would stifle creativity. In the end, the arguments in favour of copyright and neighbouring rights were stronger, and so the legislation was passed.

During debates in 1978 the topic of traditional intellectual cultural property was also discussed. It was suggested that the new legislation should also cover indigenous peoples' knowledge. It was argued that since this new legislation was intended to protect the intellectual cultural property of Papua New Guineans and to provide then with economic advantages, the legislation should be wide enough to cover 'indigenous knowledge'. However, this proposal was considered impractical for a number of reasons. One was that some of the characteristics of indigenous knowledge were incompatible with the basic requirements of copyright protection; in particular those relating to authorship, ownership, originality fixation requirements and duration provisions. A common argument was that all traditional knowledge is communally created and consequently communally owned and so belongs in the public domain. The absence of protection for other forms of public knowledge in the public domain in copyright laws of other countries was used as an argument for the ineligibility of indigenous knowledge for protection in drafting the Copyright and Neighbouring Rights Act 1978.

The proposition that all traditional knowledge is communally owned has arisen in discussions about copyright in many other parts of the world. For example, in his presentation to the Pacific sub-regional seminar on 'traditional knowledge', the Chief of UNESCO's Division of Creativity, Cultural Industries and Copyright, Professor Solab Abada, stated that

The specific issue here as compared to works of art protected by copyright, is that the expressions of folklore ${ }^{1}$ have no known author. Generally speaking, they are the product of collective people's creativity, which is never complete but constantly evolving, as the social life of the local community itself evolves (UNESCO 1999:126).

This idea originates from UNESCO's definition of traditional knowledge, as expressed by another UNESCO official, Noriko Aikawa ${ }^{2}$

Folklore (or traditional and popular culture) is the totality of tradition-based creation of a cultural community, expressed by a group or individuals and recognised as reflecting the expectations of a community in so far as they reflect its cultural and social identity; its standards and values are transmitted orally, by invitation or by other means. Its forms are among others, language, literature, music, dance, games, mythology rituals, customs, handicraft architecture and other arts (UNESCO 1999:113). 
This chapter uses examples drawn from the knowledge owning system of one Papua New Guinea group, the Tolai, to refute the assumption that all traditional knowledge is communally owned in Papua New Guinea. The chapter demonstrates the complexity of issues in Tolai practices of ownership of traditional knowledge. Tolai ownership systems clearly recognise three different levels of ownership-the individual, the vunatari (clan) and a strictly delimited or 'defined' public. Over time knowledge may pass from the individual to the group and then to the public while remaining the property of the person who originally possessed it. Ownership at these different layers is protected by supernatural powers and secrecy (pidik). The level of ownership is determined by the manner in which knowledge is acquired. The Tolai acknowledge five ways of acquiring knowledge: barawon (dream), buai (school), tinbar (gift), pinapa (purchase) and waki (inheritance).

This exposition of the Tolai system of ownership of knowledge is in no way an argument that Tolai and the wider Papua New Guinea traditional knowledge ${ }^{3}$ can be protected under a standard copyright regime. Rather, its purpose is draw attention to some of the difficulties in developing mechanisms to apply copyright to the protection of traditional knowledge. The premise is that mechanisms can only be developed from a clear understanding of indigenous systems of knowledge.

\section{Tolai systems for maintaining and safeguarding knowledge}

The Tolai are Melanesians who live on the Gazelle Peninsula at the northern tip of the Papua New Guinean island of New Britain. Before sustained contact with the outside world began in the 1870s, the Tolai lived in hamlets comprising several clans or sub-clans. Not all members of a sub-clan or clan lived in the same hamlet. Usually they were spread out over a number of hamlets.

The basic social unit of Tolai society the vunatari (clan). Descent in the vunatari is through the maternal line. The vunatari is the sociopolitical unit and to some extent economic unit, although the sub-clan (apik tarai) is the property owning unit. The kinds of properties owned by the clan range from immovable property such as land, to movable property such as canoes to intangible properties such as healing knowledge.

Ownership of knowledge among the Tolai is highly regulated, and the ways of acquiring it are clearly defined. Knowledge is owned either by 
an individual, a group or the wider public and may be protected by means of pidik (secrecy). ${ }^{4}$ A particular a class of spirits known as turangan are present in the creation, transfer and use of knowledge.

\section{Turangan—supernatural forces}

Different spirits are associated with different ways in which knowledge is imparted. If a person acquires knowledge in their sleep through barawon, it is the turangan (spirit), which brings the knowledgewhether it is a song, dance or tubuan design. The same is true of acquiring knowledge through buai (school). In going through the school, the person merely acquires the ability to be associated with spirits that later begin to deliver knowledge to him. After receiving knowledge, the individual has a responsibility to divulge it. The spirit does not only deliver the knowledge to a person, but continues to be a part of that knowledge and becomes its performance or activating power. Knowledge is rendered useless or ineffective without the presence of the spirit.

The presence of supernatural forces is also important in the transfer of knowledge from one person or group to another, such as through pinapa, tinbar or waki. Both parties to the ex-change of knowledge have a duty to ensure the transference of the spirit.

The supernatural or force component of knowledge is normally referred to as warwul (literally meaning 'swear words', but which can be translated as 'chant'). Holders of knowledge explain that the warwul is the wuwu na nilaun (breath of life). The agent which activates knowledge and brings it to life. This same phrase is used in the Kuanua (Tolai) Bible to refer to the breath of life given by God to Adam and Eve.

Anyone may know which plant materials are used for healing or other kind of knowledge and may observe the various ritual actions and procedures involved in the performance of healing, knowledge, magic or dance. But they cannot claim ownership of the knowledge these plants and rituals are associated with nor can they practice this knowledge. Rights to knowledge are determined by possession of the warwul. At all times the owner of the knowledge keeps this warwul as pidik (secret) from everyone including family, clan members and close friends.

Although warwul is what activates knowledge to come to life, knowledge itself has a supernatural force. This makes it dangerous to use the knowledge without proper authority which may result in illness and even death. The spirit of knowledge referred to here is known as the tabaranira. 
The association between knowledge and supernatural power is even stronger in the case of tubuan mask designs. Although tubuan are understood to be spirits in themselves, a distinction is maintained between the mask as material inanimate object and the spirit that it represents. When materials such as cane and cane leaves are gathered for the mask, these are still just inanimate objects that are known as nilip (gathered elements). They remain non-sacred objects while the mask is constructed. Only when the mata (eye) designs have been painted on the conical tops do they cease to be mere objects and become 'alive'. Once it becomes alive, the mask can perform the functions expected of a tubuan and with the powers accorded to it. It is able to protect itself from misuse and abuse by anyone. Anyone who tries to mistreat the tubuan or misuses or abuses any of its properties such as tabu faces instant death. This includes trying to make a tubuan mask itself without proper authority. ${ }^{5}$

The consequences for misuse of other kinds of knowledge, such as healing knowledge, dances, songs or magic, are not as severe. The offender may get severely ill-ill enough for him to let everyone know that the cause of his illness relates to tampering with knowledge without proper authority. The offender himself must reveal his offence through confession. If the person does not confess then he will become more ill and die. If the person does confess, then an antidote of the knowledge itself, known as dokadoko, is used to remove the illness.

As described above, supernatural spirits activate knowledge but they are also its source and protector. A healer may know the different kinds of herbs and the rituals of a particular medicine but he has to harness the powers of the spirits to successfully practice the knowledge. In dance, talent, skill and even experience are not as important as knowledge of how to harness the power of the spirits through the ritual known as wapapa (to shed weights). This is performed to invite the spirit to puak (carry) a person during dance, in order for him to perform with elegance.

\section{Pidik - secrecy of knowledge}

Pidik relates to the maintenance of secret knowledge by the men away from the uninitiated young boys and women of the village. In most ethnographies of Tolai, the concept of pidik is associated with the religious domain, in particular tubuan society ${ }^{6}$ (Epstein 1969; Salisburry 1970; Errington 1974; Neumann 1992). The maintenance of secrecy by the members of the society is important to the continuity of the 
tubuan. In the tubuan society, pidik is to be maintained especially in relation to the belief that the mask is actually a spirit. Within the society, secrecy is also maintained between groups, in particular clans, who protect knowledge about each other's tubuans. Individuals who possess particular kinds of magic and ritual processes associated with the tubuan also maintain pidik about them from their own clansmen and the wider tubuan society.

In his discussion on 'affect' among the Tolai, Epstein discusses pidik in relation to control of information

'Secrecy is about the control of information'; it is in this regard a matter of power.

Among the Tolai, this is readily seen in a number of institutionalised contexts. In the case of the tubuan for example, acquiring the pidik, the secret is central to the process by which the initiation moves from one stage to the next. Again, secrecy seems to have been essential in the performance of many magical rites. In some forms of garden magic, for example, while one man performed the rite on behalf of a group, more might draw near the magician while he uttered his incantation lest they overhear his spell; later each individual would cast his own spell (Epstein 1992:109)

\section{He continues}

Thus one's preparation for a balaguan or some similar event were a closely guarded secret, u vaninar kauku pidik (preparing a persons pidik) - the nature of one's ornamentation, the design of one's kangal or headgear, one's matatar, the daubing of the body with lime powder, and so on, all needed to be kept hidden from the knowledge of others (ibid:109).

An example of the presence of pidik in the secular domain relates to the clan, the land-owning unit. Each vunatari has a history that is known by some of the senior members of the group. This history includes information about the clan's ancestors, their names, where they lived, the battles they fought, where some of them were buried, the lands they cleared and planted and what human remains they left along the way. Such knowledge is very important to the identity of the group and the determination of land ownership. Tolai land holdings stretch over a number of different areas, consistent with the movement of the group in ancestral times. The clan's history tells of the places its members settled as theirs, the events that took place and the evidence they left behind-such as fruit trees and human remains-which supports their claim to that land.

The history of the clan is a matter of great pidik. It is carefully guarded by the senior members of the vunatari. Only parts of the 
history are made public when absolutely necessary. Otherwise it is a body of knowledge which is kept as pidik most of the time. In his writings about the Matupit, Epstein discusses they way in which clan histories are used in land disputes. ${ }^{7}$ In these disputes, a clan that cannot present its history has very little chance of successfully establishing its claim to land. At the same time, a clan whose history has become common knowledge to everyone also has less chance of making a successful claim to land. This is all the more important reason to maintain pidik in relation to clan history.

In addition to the tubuan and the vunatari, pidik is also found in everyday life and in the ritual domain. In everyday life, matters such as a person's wealth and his skills are matters of pidik. It is said that public knowledge of this wealth can endanger a person's life. Pidik is kept in relation to skills such as canoe making, gardening, fishing or hunting to ensure that this skill is kept within the vunatari or passed on to a selected person. In the realm of ritual, the observance of pidik is found in the preparation and performance of music, dances and making of head-dresses, ritual costumes and healing magic and practice.

When songs are composed, they usually have a story-line and background to composition. While the music may be heard by the public, the story-line and background information to composition are kept as pidik. These two pieces of information are important to the understanding and appreciation of the song. It is often quite difficult to ascertain the story-line from the lyrics, which are often written in an archaic language. Dances similarly depict story-lines and events that are not readily deciphered from a performance. Dances are covered by pidik and rehearsals, known as kunubak, are done in secret in the bush. Rehearsals may take days in the case of male dance. Preparation for women's dances involves kunubak but takes place on the periphery of a village rather than the bush.

In the pursuit of magic and healing rituals, people may see a person performing the actions of ritual but an important part of this process is the chants, which are known as warwul. Warwul is also the subject of great pidik.

There are specific situations in which pidik may be lifted for designated persons under strict conditions. Where clan information is kept under pidik particular members may be granted access as in the cases of tubuan and clan histories. The release of the pidik knowledge of an individual is at the individual's discretion. 


\section{Acquiring knowledge}

The Tolai acquire knowledge in one of five ways: barawon (dream), buai (school), tinbar (gift), pinapa (purchase) and waki (inheritance). Other than by theft, knowledge may be acquired for use for a limited period. Temporary use is known as totokum (hire) and involves payment of tabu for specific uses and set periods.

\section{Barawon-dream}

A person can come by a new song, tubuan design, dance, magic or healing magic, through a dream. A dream indicates that a person has been visited by a spirit. People do not know why the spirit, or turangan, comes and the occurrence is always surprise. The spirits and knowledge first come to a person suddenly. The people most likely to be approached by spirits are persons who spend a lot of time by themselves, such as those who are lonely and, in many cases intellectually and/or physically disabled.

\section{Buai-school}

Among the Tolai certain artistic skills, such as composing dances or music and design or painting, are transferred through buai. While the literal translation of buai is actually betel-nut, its closest meaning in English is 'school'. There are buai na pepe (schools) of music, dance and artistic design, which come under the name of the leading 'masters' of these arts. Neumann (1992) discusses the practice of buai.

Buai is the most common carrier of all kinds of magic; love magic, black magic (taring), magic to enhance one's knowledge and others. Buai can become a synonym for the magic itself. Through the buai na pepe, men can communicate with spirits who advise them on the choreography of a dance, the text of a tapialai, or the recipe for taring (Neumann 1992:90).

Traditionally buai was a very involved matter, both for the tena buai (sponsor) ${ }^{8}$ and the 'candidates'. The sponsor, often a man with an established reputation of having a particular kinds of knowledge, would announce and then organise an occasion when candidates could come to receive buai from him. On the occasion he proposed, a loga (platform) would be placed at a designated location somewhere in the bush. On this loga different buai would be displayed for sale to interested candidates. The candidates come with an amount of tabu to inspect the 
loga. After inspection of the loga, they pay pieces of tabu for the items of their choice. These items are sold to dok (pay) for the buai.

The item sold is a small parcel about the size of a strawberry which contains a mixture of herbs and perhaps a little bit of betel-nut. This is eaten by the candidate. During the eating of the parcel the candidate is also given the warwul (chant) of the buai. He now possesses both the physical and chant components of the buai. After the 'eating' of the buai, the candidate has to go through the process of nilip (accessing) the herbal ingredients of the buai, which requires the mastering of certain skills and knowledge of additional chants. This involves the candidates staying in seclusion for a few days to a week. ${ }^{9}$ What has been described here is the traditional process of buai, which was practiced in almost the same format even up until the 1970s. It is still practiced today, but not strictly in the same format.

Today tena buai still hold such occasions, but they are not open to the public. Buai are done on request or invitation, and are often smaller affairs involving only a handful of candidates. However, the rules are still basically the same; the tena buai prepares the 'parcels', the candidates come and pay with tabu and then 'eat' the buai and also receive the warwul and then go through the nilip. These rules are still very strictly followed.

Having gone through a buai does not mean that the person now depends entirely on his newly acquired skills to perform. Instead, the school only conditions him to be more accessible to the supernatural world, which is the main source of all new knowledge. The agents of the supernatural world in this scheme are the turangan.

Knowledge acquired in the first instance in this way belongs to the individual.

\section{Tinbar-gift}

Some kinds of traditional knowledge, such as rituals and healing knowledge are acquired through tinbar. A person in possession of ritual or healing knowledge may decide to give this knowledge to a friend, relative, associate or assistant.

A gift recognises a special relationship between the two persons and/ or recognises the support of one party for the other. Tinbar goes to a person who has demonstrated interest in that knowledge over the years and has the skills to use it. In some cases the hopeful receiver's expectations are fulfilled, but in others he may be disappointed. In some ways the knowledge being given as tinbar is not actually a gift, because the 
receiver does have to pay in other ways, such as in kind. It is the lack of transfer of tabu which classifies the transfer as a gift.

The transfer of knowledge by tinbar is a formal affair. The actual transfer of the knowledge is done privately between two persons. Later it is formalised by a small feast, attended by a few people, mainly for the purpose of witnessing the transfer and also to endorse it.

The knowledge acquired as such initially becomes the property of the individual.

\section{Pinapa_purchase}

Among the pre-contact Tolai trade was facilitated by tabu, a medium of exchange with similar characteristics to those of a currency. Tabu (shell money) was largely a ritual object but it was and is still used in many day-to-day transactions. As long as someone is willing to sell, a person wanting to acquire knowledge of any kind can purchase it with tabu.

As with tinbar, the transfer of knowledge pre-supposes an existing relationship. The only difference is that the relationship need not be as long standing as it must be for tinbar. The vendor requires a reasonable period of familiarity with the purchaser in order to meet certain considerations. One of these important considerations is the vendor's satisfaction that the purchaser will not misuse the knowledge, considering that some knowledge may have both malevolent and benevolent powers. The vendor also has to be satisfied that the purchaser will protect the knowledge from abuse and misuse by others. When the vendor is satisfied that these matters are in order, a transfer is made between the two persons in private. This is followed by a small feast in which the transfer is made public.

Knowledge acquired by pinapa initially becomes individual property.

\section{Waki-inheritance}

Some kinds of Tolai knowledge are clearly the property of clans but can only pass from person to person through inheritance. This is the case for ritual property such as songs, tubuan designs and dances. Knowledge acquired in this way can pass to an individual but it remains the property of the clan. The underlying rule is that all property belonging to the vunatari can only be passed onto the clan. If an individual member of the clan owns property which he has not disposed of to another person during his lifetime; at his death the property 
immediately belongs to the clan. On some occasions the clan may agree to transfer some of its property to others but this has to be agreed on by all members. Transfers of this kind are very limited-they can be made to either members of allied clans or children of the owing clan.

\section{Individual ownership}

Individual persons own both tangible and intangible property. Tangible property that can be owned by individuals includes canoes, gardens, fruit trees and houses. Intangible property includes songs and dances, designs for dance costumes, tubuan designs and healing practices.

Some songs and dances are the property of individuals. If another person wants to use the songs and dances during the lifetime of the owner, a performance fee must be paid to the owner. A person may also dispose of the ownership of a song or dance to another person for payment in tabu.

The knowledge of healing practices can also be owned by a person. This knowledge is obtained either through barawon, buat, tinbar or pinapa. The story of Joseph ToBavul illustrates this. ToBavul is a healer from Vunapaka village in the north-coast hinterland of the Gazelle Peninsula. ${ }^{10}$

Originally, I started working as a healer as an assistant to my father who was then a healer. When my father was a healer he used to send me to collect the ingredient plants from his medicinal mixtures, but at that time I did not know the chants that went with the mixtures.

Although I knew the various types of plants and how to mix them, I could not practice the art of healing because I did not know the accompanying chants.

Knowing the different herbs and how to mix them, I felt that I could almost practice healing but I knew that without the chants this knowledge was useless. When my father was very old I asked him for the chants. I was very pleased when he, without hesitation, gave it all to me.

In the beginning I tried out some of the healing-firstly on my wife. I did not want to try it out on other people, just my wife. There were a number of times when my wife had come close to death, but with the aid of my newly acquired knowledge I managed to bring her back to good health.

Twice my wife had two dead foetuses inside her. I tried the prescribed cure obtained from my father and I managed to get them out. I continued trying out my 
knowledge on my wife for a while. Gradually I tried it on other people. It was successful and very gradually I developed confidence in my ability.

After some time people began to hear about me as a healer and began to come to see me with their illness. In the beginning it was mainly people from my village and nearby villages who came to see me. Later people from distant villages also heard about me and came to see me. Now I have people from all over the Gazelle Peninsula coming to see me. Later, after I had been practicing for some time, I began to want to acquire other healing medicines from other people (ToBavul, personal communication). ToBavul then acquired a number of different kinds of medicine to add to his knowledge.

A kutu (the vomiting of blood). I acquired this medicine from a man called ToRarong from Tavuiliu village. I paid only five fathoms of $t a b u$ for this, as this man was a distant uncle of mine.

Waliklikum (antidotal magic). I acquired this from a matrilineal uncle of mine, ToNgale. He had acquired this medicine from Tolagat of Nodup Village. ToNgale had bought this for fifteen fathoms of tabu. I prepared some food and ten fathoms of tabu, brought it to ToNgale's house and acquired this medicine.

In acquiring this particular medicine I seemed to have been lucky. The time thar I came to ToNgale's house he was dying. Thus, as he had no one to give his other healing knowledge to he decided to give them to me. So I was able to acquire other healing knowledge including the kilang (clairvoyance) (ToBavul, personal communication). Joseph ToBavul acquired knowledge for about 20 healing practices from his father, for whom he had acted as assistant. He had also purchased or acquired in other ways about 15 other different medicines. In 1982, at the end of my interviews with him, Joseph ToBavul was considering what would happen to this knowledge. He told me

At the present time both the people of my own matriline and my own children are squabbling over who should acquire this healing knowledge from me.

At present I think my own son ToMitil will get these things because he has acted as assistant to me for some time now. My son now already knows the plants that I use and how to mix them, but he still does not know the chants.

There is also a grandson of mine (a son of ToMitil) who has also worked with me and knows the plants. But like his father, he also does not know the chants. This grandson might also share some of the knowledge with his father.

By and by I will give them the chants (ToBavul, personal communication). 


\section{Group knowledge}

The Tolai clan, or vunatari, is the basic social unit. It is comprised of members of a matriline who recognise a common female ancestor. The clan owns tangible property including land and fishing grounds, fish nets and traps and canoes. A clan also owns intangible property including tubuan designs and magic, songs, dance head-dress and necklace designs and the oral history of the clan.

All tubuan are owned by clans. Some clans may have more than one tubuan, but most clans have one. One man, usually an elder member of the tubuan society, manages each tubuan. A tubuan represents a spirit, sometimes the spirit of ancestors. The tubuan are passed down from generation to generation. Each tubuan is of a particular design, has a particular kind of magic, observes particular taboos and is said to consume only particular kinds of foods. This knowledge is passed down from one generation to the next, usually through male members of the matriline who are members of the tubuan society. It is very jealously guarded from the members of other clans.

In some cases the design and knowledge of a particular tubuan does not get passed down through the matriline. It may be transferred by a father to his son because the father did not have any descendants of his matriline who were old enough to receive it. In this case, at a later stage a descendant member of the matriline will 'buy back' the design and magic knowledge from the father's son. The price in tabu for this purchase is small, representing only a fee to the person who has looked after it. In other cases a clan may lose the design and magic of its tubuan forever. The clan then has to buy a new tubuan. In this case the purchase amount is quite substantial.

Dance head-dress designs are very important to Tolai cultural life. These designs embody and represent the spirits of ancestors and have been passed down from generation to generation. All members of the clan guard these very closely. On some occasions the designs may be borrowed by the members of other clans for use in particular rituals. Permission has to be obtained from the owning clan and a fixed payment of tabu is made.

As described above, each clan has an oral history that contains the names of its ancestors, how they migrated, where they settled, with whom they interacted and how they came to own property. All members of the clan must have this information. The importance of this kind of knowledge becomes apparent during disputes over property, 
particularly land and ritual designs. This knowledge is closely guarded as it can sometimes be 'stolen' by other groups who may graft it onto their own history to support an opposing argument.

Songs, which can be for either dancing or singing, are the property of an individual. When the individual dies, the songs become the property of the clan. In the custody of the clan, the songs can be used by its members and are hired out for a fee to members of other clans.

\section{Public knowledge}

Public knowledge is knowledge that everyone in society knows or has a right to access, including marriage procedures and gardening or fishing techniques. Knowledge of some songs, rhymes and most children's songs, rhymes and games is also public knowledge. Songs, dances and other knowledge which have originated from other groups are also included. For instance, for some time now the Tolai have been performing a number of songs and dances which belong to Solomon Island groups and also some from New Ireland. They are known as limilibur (entertainment) songs and dances. Generally public knowledge either has no significant ritual value or has origins elsewhere. However, as is discussed below, some public knowledge has significant ritual value.

The public sphere is usually defined by the social boundaries of the village, but for some kinds of knowledge this sphere extends beyond the village. For the purpose of describing these rules, the members of a village with public knowledge can be called Group A. Beyond the village are two categories. First, those from nearby villages or communities who cannot help but pick up some of the knowledge from their neighbours, Group B. The second category are those who live in distant villages, but are related to Group A. These people constitute Group C.

While knowledge might be said to be public and accessible to or for use by anyone, this is only completely true of the members of Group A. A member of that group may utilise public knowledge of the group within the group's territory and no one will complain. Members of Group B also have access to the knowledge, but acknowledge that it belongs to Group A. On occasion the members of Group A will remind Group B of this fact. The knowledge of Group A is also accessible to members of Group C. Persons in this group utilise the knowledge, perhaps out of habit like members of Group A. These persons and the people among whom they may be living know that this knowledge belongs to Group A. 
Tolai society recognises a 'defined public' beyond which there are 'others'. Others may choose not to use this knowledge for fear of offending the 'defined public' or simply have no desire for it. In a situation where persons outside of the defined public use knowledge belonging to the group, the worst that can happen to them is that they will be ridiculed and made fun of. The normal rules of ownership, rights and claims are not applied here.

Most of the knowledge in the public domain has no significant ritual value. Knowledge which does have ritual value in the public domain usually arrives there by accident. Once in the public domain, knowledge cannot be retrieved. The use of this knowledge is often a matter of contention between villages and groups, and its use is closely scrutinised for abuse or misuse.

The case of Kabakavir music, a category of tubuan songs, can be used to illustrate this. Kabakavir was a man who lived about 150-200 years before the first white man arrived on the Gazelle Peninsula in East New Britain Province. He was a little man in size and had the skin disease grille. ${ }^{11} \mathrm{He}$ lived at the village of Raluana on the other side of Blanche Bay from Matupit Island, very close to where the township of Rabaul is now located.

Because of his small size and his skin disease, Kabakavir was ostracised. He sat alone on beaches, up in trees or in the bush. Being away from everyone else, he found comfort and company in composing and singing songs. He started singing songs that were similar to those of the tubuan society. As he was not a member of the tubuan society at Raluana, Kabakavir did not know any proper tubuan songs. When the tubuan men of Raluana heard him singing his songs they recognised them as being related to the tubuan songs and were angry that a nonmember would compose them. Non-members are not allowed to sing these songs. They were offended, thinking that Kabakavir was making a mockery of their society. They chased him into the bush and banned him from entering the village again.

Some time later Kabakavir managed to get a canoe and travel to Matupit Island on the other side of Blanche Bay where he had relatives. On Matupit the men of the local tubuan society did not question his membership in the tubuan society at Raluana. They allowed him into the taraiu (tubuan sanctuary). While at the tubuan sanctuary on Matupit Island, this little man sang his songs. The men of the tubuan society at Matupit liked his music. They encouraged him to teach them and to 
compose more songs. He did this and by the time of his death he had left a legacy of between 80 to 100 major pieces of tubuan music, later known as Kabakavir music.

On his death, the body of Kabakavir was taken back to Raluana village for burial. There are conflicting stories about his burial. The Matupit version says that the body was in fact not sent back to Raluana. Instead, a banana trunk wrapped in pandanus leaves was sent while the body was actually buried at Matupit Island. The Raluana version says that the body was buried at Raluana. Another version is given by a member of the clan of Kabakavir. According to this version, when the body was received from Matupit it was not buried in the place where everyone thought it was buried. Instead, a substitute banana trunk was buried there. The actual body was buried in a secret place only known to some members of Kabakavir's clan.

Kabakavir music is now an established category of tubuan songs within the genre known as tapialai, which includes liu, alalu, buai and Kabakavir. Liu, alalu and buai categories of tubuan music are sung in all parts of the Gazelle Peninsula and the Duke of York Islands where tubuan are found. Kabakavir, on the other hand, is restricted to Matupit Island, two nearby villages (Talwat and Baai), Raluana village and Vunapaka village in the north-coast hinterland. Matupit Island members of the tubuan society lay claim to the largest number of Kabakavir songs. On the basis of this and the assumption that most of these songs were composed on the island, Matupit islanders claim ownership of the variety of music. The fact that Kabakavir lived on the island until his death adds weight to their claim.

At Talwat and Baai villages, a small number of Kabakavir pieces of music are played. The tubuan men of these two villages do this with full knowledge and acknowledgment of this variety of music as having its origins in Matupit Island. The tubuan men of Vunapaka village in the north-coast hinterland also know a few pieces of the Kabakavir music. Someone there had even begun to compose music along Kabakavir lines. A member of Kabakavir's clan of Matupit Island brought it to this part of the Gazelle Peninsula. Kabakavir music lives on and is developing in this area, with the clear understanding that it belongs to Matupit Island. The person who is now composing Kabakavir songs at Vunapaka is a descendant of the person who originally introduced the music there.

At Raluana village the men of the tubuan also know only a portion of the Kabakavir music that is found on Matupit Island. They do not agree 
that this music belongs to Matupit Island. They say the music belongs to Raluana, because Kabakavir came from there originally and that on his death he was buried there and so his spirit is there. Further, the descendants of Kabakavir's clan claim that they have possession of his bones, which they use for buai na pinpit (music composition magic).

\section{Conclusion}

Increasing globalisation threatens the ability of communities in Papua New Guinea to control access to and use of their traditional knowledge. There are a number of ways in which traditional knowledge could be protected, including by patent, sui-generis systems, or a modified version of copyright. In developing any mechanism, there must be a clear understanding about how indigenous systems work, rather than broadbased assumptions.

One idea which might easily form part of the development of a mechanism for protection of traditional knowledge is the assumption that all traditional knowledge is communally owned. This discussion of the Tolai system of knowledge shows that people were very particular about acquisition, ownership, transfer, protection and use of knowledge. Only some kinds of Tolai knowledge belonged to the public domain, while the rest belonged to individuals and social groups. If an appropriate system of protection is to be developed for Papua New Guinea which is sensitive to systems like those of the Tolai, it is important that these nuances be properly understood.

\section{Kuanua glossary}

apik tarai

balaguan

barawon

buai na pepe (buai)

buai na pinpit

dodoko

dok

dokadoko

Kabakavir sub-clan

mortuary feast

dream

school for transmission of knowledge

music composition magic

antidote used to remove illness caused by unauthorised acquisition of knowledge

pay

protective magic

a category of tubuan music 


\begin{tabular}{|c|c|}
\hline kangal & headgear \\
\hline kilang & clairvoyance \\
\hline Kuanua & Tolai language \\
\hline kunubak & preparations for dancing, conducted in secret \\
\hline kutu & healing practice involving vomiting of blood \\
\hline limilibur & $\begin{array}{l}\text { entertainment songs and dances that are } \\
\text { publicly owned }\end{array}$ \\
\hline $\log a$ & platform \\
\hline mata & eye designs on a tubuan mask \\
\hline matatar & $\begin{array}{l}\text { preparation of a person's body with lime } \\
\text { powder }\end{array}$ \\
\hline nidok & $\begin{array}{l}\text { period of seclusion associated with transfer of } \\
\text { knowledge during buai }\end{array}$ \\
\hline nilip & $\begin{array}{l}\text { gathered elements for construction of a sacred } \\
\text { object; also 'to access' }\end{array}$ \\
\hline pidik & secrecy \\
\hline pinapa & purchase \\
\hline puak & $\begin{array}{l}\text { literally 'carry' (possession of a person by } \\
\text { spirits during a dance) }\end{array}$ \\
\hline tabaranira & spirit of something \\
\hline tabu & traditional shell money \\
\hline tapialai & $\begin{array}{l}\text { genre of tubuan music including kabakavir, liu, } \\
\text { alalu and buai }\end{array}$ \\
\hline taraiu & tubuan sanctuary \\
\hline taring & sorcery \\
\hline tena buai & sponsors of a buai or 'school' \\
\hline tinbar & gift \\
\hline totokum & hire \\
\hline tubuan society & society of initiated men \\
\hline tubuan & $\begin{array}{l}\text { spirit belonging to a clan (sometimes the spirit } \\
\text { of ancestors) }\end{array}$ \\
\hline turangan & spirit \\
\hline u vaninar kauku pidik & preparing a person's pidik \\
\hline vunatari & clan \\
\hline waki & inheritance \\
\hline walikikum & antidotal magic medicine \\
\hline wapapa & to shed weights (a ritual used to harness spirits) \\
\hline warwul & chant \\
\hline wuwu na nilum & breath of life \\
\hline
\end{tabular}




\section{Notes}

1 'Folklore' is the term used by UNESCO to mean 'traditional knowledge'. This particular terminology has had difficulties being accepted by many member states of UNESCO. France does not accept this because the French translation is derogatory. A number of African counties also want this term to be phased out of usage. At the 1999 UNESCO sponsored Symposium on 'The Protection of Traditional Knowledge' in Noumea, there was strong opposition to using the term by most Pacific Island countries except for Australia.

2 Ms Noriko Aikawa is the Chief on the Intangible Heritage List, UNESCO. The definition she gives here is actually the one used in the 1989 'UNESCO Recommendation on the Protection of Folklore and Cultural Expressions' and appears in Chapter 1 of the document.

3 The term 'rights' has to be used here with reservation, as there seems to be difficulty in the translation of this term into Tolai. This has implications for possible inappropriateness of the concept itself.

4 The concept of ownership also has to be used with caution, as its usage also has implications on the concept of 'rights'.

5 Only the applications of dokadoko (protective magic) can stop this. Each knowledge has its own protective magic, so the right one has to be used. Any other protective magic would not have any effect.

6 The tubuan society is a fraternity, also commonly known as a secret society. It is represented by a mask known as tubuan. Membership is restricted to adult males and older boys, but involved the payment of an amount of tabu (shell money).

7 Epstein's work among the Tolai in the late 1960s was mainly centered on 'land tenure'. A great deal of his time was spent on land disputes, which took place between different clans.

8 The 'sponsor' is the person who prepares the occasion. He meets all the costs of putting the loga together. It is like a commercial investment, which took place between different clans.

9 Today the seclusion in the bush is not always observed, although it is still very strictly observed on occasions of acquiring knowledge relating to tubuan. In this case the seclusion period is known as nidok, involving a period of two weeks and still practiced on the Gazelle Peninsula.

10 This account was recorded in 1981 during my doctoral fieldwork.

11 Grille is a fungal disease causing patches of discolouration on the skin. 


\section{5 \\ The National Cultural Property (Preservation) Act Mark Busse}

We must build a nation in which tribal languages and cultural boundaries are transcended, not for exploitation of one group by another but for mutual support of each other (Narokobi 1980:78).

The people of the Lake Murray-Middle Fly area of Western Province, among whom I carried out anthropological research in the 1980 s, said that objects could never be separated in any way that mattered from the people who made them, and that one could always see the person who made an object in the object that he or she made. This was a striking claim about the relationship between objects and people and an astute statement about the complexity of objects and the capacity that certain things have for evoking complicated thoughts and feelings in those who see them or interact with them. Objects are more than physical things. They are manifestations of creativity, knowledge, physical skill (which is a type of embodied knowledge) and social relations. Garamuts from the Sepik River are not simply carved and hollowed out logs which can be used to produce sound-they are the products of the skill and genius of the persons who carved them. They contain and express the beliefs and aesthetics of the people who make and use them, and they are embedded in a system of social relations, both in their ownership and their production, for the person-in-the-object is a social person.

An object can have different meanings for different people, and the same object can have different meanings in different contexts-different 
places, different times and different events. The significance of a garamut is different for men and women or for older men and younger men in its home community. Similarly, its meaning is different depending on whether it is in the village haus tambaran, the National Museum in Port Moresby or an auction house in Sydney, London or New York.

This chapter explores the multiple and often intricate meanings of a particular category of objects-national cultural property-with reference to the National Cultural Property (Preservation) Act which, according to its preamble, is 'an Act relating to the preservation and protection of objects of cultural or historical importance to Papua New Guinea'.

The relevance of national cultural property to the broader issues of intellectual property in Papua New Guinea is two-fold. First, inasmuch as cultural objects are manifestations of knowledge, creativity and social relations and cannot be separated from these, they are a type of intellectual property. Second, the National Cultural Property (Preservation) Act provides an example of legislation which already exists in Papua New Guinea that is designed to protect a particular form of intellectual property. Therefore, it is worth considering the historical development and provisions of this law, as well as how the law is implemented and enforced.

A consideration of the National Cultural Property (Preservation) Act suggests some important questions that need to be asked in the development of intellectual property legislation. Some of these questions relate to definitions of property and ownership-how we think about the basic multiple relationships between people and things. Others concern the possibility that certain types of property should be protected-and, if so, how and from whom-and whether there are objects that should not be considered property at all. Additionally the National Cultural Property (Preservation) Act raises important questions about how a national government, through intellectual property legislation for example, might act on behalf of the plurality of people who make up the country. These are fundamental questions that arise repeatedly in working with the National Cultural Property (Preservation) Act, and they are the types of questions which must be asked in the process of developing intellectual property legislation. 


\section{History}

The historical context of the development of cultural property legislation in Papua New Guinea is that of European colonialism. Since the fifteenth century-when both European colonial empires and the systematic collection of antiquities and artifacts by Europeans had their beginnings - war, colonial administration, the desire for scientific knowledge, economic power and theft all contributed to a flow of cultural objects out of colonies and into the powerful countries of Europe and America. The collections in the great eighteenth and nineteenth century museums in cities such as London, Paris, Madrid and Berlin were closely linked to the military, commercial and colonial activities of their governments abroad (Ley 1991:14-16).

The flow of cultural objects from Africa, Central and South America and the Pacific into countries in Europe and North America continues today, although on a lesser scale. The reduction in the movement of cultural objects has been due in part to the efforts of organisations such as UNESCO - which has encouraged greater respect for nonWestern cultures and greater international cooperation concerning cultural property - and in part to the efforts of previous colonies to enact and enforce legislation to protect their cultural property (ibid:1416).

The first legislation regulating and restricting the trade and export of cultural property in what is now Papua New Guinea was instituted in the Territory of Papua in 1913. Since then, the laws that deal with cultural objects have developed in response to changing local attitudes about cultural heritage as well as international developments concerning the protection of cultural property. Throughout these changes, what has remained fundamental has been the assertion by the government-first the colonial government and then the government of the independent state - of the importance of restricting the acquisition, ownership and movement of certain objects and categories of objects thought to be important to a wider segment of people than those individuals or groups who owned or controlled them.

The historical discussion that follows focuses on the definitions of cultural property and the kinds of restrictions imposed by the government on movement and ownership of that property. 


\section{The Papuan Antiquities Ordinance (1913)}

Ordinance Number 14 of 1913 (Section 2), titled 'An Ordinance Relating to Papuan Antiquities', defined Papuan antiquities to include 'Papuan relics' and 'such articles manufactured with Papuan tools and according to Papuan methods and such other articles and things of historical or scientific value or interest and relating to Papua as may be prescribed by regulation'.

The 1913 Ordinance made it illegal to remove Papuan antiquities from Papua without first offering the objects for sale at a reasonable price to the colonial government. Enforcement of the Ordinance was 'the duty of all European [meaning white] constables and officers of the Customs' who were given the power to 'seize and detain' any antiquities that were being removed from the Territory. The penalty for exporting Papuan antiquities from the Territory without the written permission of the Commissioner for Native Affairs and Control was a fine not exceeding $£ 100$ or, in default, imprisonment for a period not exceeding six months with or without hard labour--substantial penalties for that time. The Ordinance also provided that any Papuan antiquities entered or shipped for export without the permission of the Commissioner for Native Affairs and Control were to be forfeited and vested in the King 'for the use of the people of the Territory'.

The Ordinance was, not surprisingly, very paternalistic. The emphasis was on how an object was made rather than on the meaning of an object for the people who made and used it. What constituted Papuan tools and Papuan methods was assumed to be non-problematic. ${ }^{2}$ There was no suggestion that colonial officers should consult with Papuans or in any way seek their views about what kinds of objects should or should not have been protected under the Ordinance. It was the duty of white police constables and white customs officers to enforce the Ordinance, and they had the power to seize Papuan antiquities which would then be forfeited to the King. It was not the responsibility of indigenous police constables, and no mention was made of the possibility of returning seized objects to the communities from which they had been removed. From the determination as to which objects were worthy of protection to the final disposition of objects that people tried to remove illegally from the Territory, Papuan antiquities were assumed to be the exclusive concern of the colonial government.

The temporal distance contained in the phrase 'Papuan antiquities' underlined the separation between Europeans and Papuans. The word 
'antiquity' generally refers to ancient times or to objects of great age. The only references in the Papuan Antiquities Ordinance to the past or to the age of objects, however, were implicit in the definition of Papuan antiquities as including relics and things of historical value. ${ }^{3}$ Despite the fact that the Ordinance was explicitly about antiquities (and thus, it would seem, about objects of great age), it is clear from the definition that objects still being 'manufactured with Papuan tools and according to Papuan methods' in 1913 were also considered antiquities, implying that the people who made such objects were living in the distant past.

The dismissal of Papuans and the objects that they made to the distant past was compatible with early twentieth century European ideas about social evolution which expressed the differences between Europeans and non-Europeans in evolutionary and thus temporal terms. This temporal distancing was not only manifested in colonial ordinances such as the Papuan Antiquities Ordinance, but was also reflected in statements characterising Papuans as living in the stone age or in formulations such as 'the land that time forgot' and '10,000 years in a lifetime'. These characterisations continue to influence Western images of Papua New Guinea today and have been an enduring part of the marketing of Melanesia as a tourist destination for the last 70 years (Douglas 1996:174-80).

\section{Regulations under the Papuan Antiquities Ordinance}

During the 40 years following 1913, regulations made under the Papuan Antiquities Ordinance suggest the kinds of conflicts to which the Ordinance gave rise. These regulations further defined the objects protected under the Ordinance, the administrative procedures through which permission to remove antiquities from Papua could be obtained and the factors taken into account in deciding to grant such permission. It is clear that these regulations responded to conflicts between

Europeans who had differing views about the appropriateness of buying, selling and exporting Papuan material culture. No evidence suggests that any regulations reflected Papuan concerns or that there was any consultation with Papuans about what should be or should not be protected.

In 1914, a regulation was made which listed the objects considered to be Papuan antiquities within the meaning of the Ordinance. The items were listed in a schedule and defined by reference to the materials from which they were made. ${ }^{4}$ At the end of the list the general definition of 
Papuan antiquities in the Ordinance was reiterated in a final catch-all phrase 'all articles manufactured with Papuan tools according to Papuan methods' regardless of material. The same regulation also listed types of items specifically exempted from the provisions of the Ordinance. These types of items did not require government permission in order to be exported. ${ }^{5}$ There is no explanation concerning why it was necessary to gazette a list of examples of Papuan antiquities in addition to restating the Ordinance's broad definition of Papuan antiquities, or why particular types of objects were put on one list rather than the other. Why, for example, were headdresses exceeding two feet in length specifically protected? Why were carvings and paintings on wood restricted, but shields were not? It is likely that the 1914 Regulation reflected a compromise between the business interest of artifact dealers and collectors on the one hand and the colonial administration's concern, for reasons which are unclear, about the wholesale export of indigenous material culture on the other.

A notice published in the Papuan Government Gazette in October 1916 and regulations gazetted in 1918 suggest that there were continuing conflicts over the buying, selling and exporting of material culture from Papua. The notice stated that 'permission will not be given to export or ship for export any Papuan Antiquities except to the accredited representative of an officially recognized scientific institution'. This was the first example of a growing justification of the exporting of artifacts from Papua and New Guinea on scientific grounds. ${ }^{6}$

The absurdities of calling contemporary objects antiquities were made clear in 1939 when the Papuan Antiquities Ordinance was amended to include archaeological objects. This amendment gave the LieutenantGovernor the authority (in Council) to 'make regulations for the preservation and acquisition of objects of antiquity' where objects of antiquity were defined as 'any archaeological treasures of the Territory not being Papuan antiquities'. 'Objects of antiquity' were thus distinguished from 'Papuan antiquities' on the grounds that the former were objects from the past discovered through archaeological methods whereas the latter were objects made by people possibly living in the present but using methods and tools belonging to a culture (Papuan) belonging to the past. 


\section{Further historical developments}

Legislation similar to the Papuan Antiquities Ordinance was enacted in the Territory of New Guinea in 1922. This ordinance, the New Guinea Antiquities Ordinance, was virtually identical to the Papuan Ordinance with many sections in the two ordinances using exactly the same words and expressions. Two amendments were subsequently made to the New Guinea Antiquities Ordinance that are significant for the purposes of this discussion.

First, an amendment made in 1923 gave the Administrator of the Territory of New Guinea the power not only to restrict the export of certain categories of objects but to prohibit the ownership of certain types of objects by certain people. The same year, this amendment was used to forbid the acquisition or transfer of ownership of human skeletal material of any type including human skulls. It was also subsequently used to prohibit the acquisition or transfer of ownership of two carvings from the Karawari River area.

Second, in 1936 authority to act under the Ordinance was delegated to District Officers in New Guinea. This delegation of authority was made in response to complaints from artifact dealers about what were perceived as unnecessary delays in the approval of exports of artifacts from the Territory.

Following the administrative amalgamation of the Territory of Papua and the Territory of New Guinea, the Papuan Antiquities Ordinance and the New Guinea Antiquities Ordinance were consolidated into the Antiquities Ordinance of 1953. This ordinance included no new provisions and simply incorporated the provisions of the two previous ordinances. It was repealed in 1965 by a new ordinance passed by the joint Territory's House of Assembly.

\section{The National Cultural Property Ordinance (1965)}

The passing of the new National Cultural Property (Preservation) Ordinance by the House of Assembly for the Territory of Papua and New Guinea in 1965 marked an important turning point in the legislation on cultural property in what is now Papua New Guinea. This ordinance, which at Independence became the National Cultural Property (Preservation) Act, replaced the language of antiquities with 
the language of national cultural property. It also gave the responsibility for the enforcement of the ordinance to the Trustees of the Papua and New Guinea Public Museum and Art Gallery, which had been established in 1954 and was the immediate forerunner of the current National Museum and Art Gallery.

The change from the language of antiquities to the language of national cultural property was important for at least three reasons. First, it removed the social evolutionary absurdity that objects produced in the present were described as objects from the distant past. Second, by defining national cultural property in terms of cultural heritage, it suggested a move from the protection of objects defined in terms of Western scientific interests or in terms of objects made in a particular way ('an article manufactured by Natives with Native-made tools and according to Native methods') to the protection of objects because they were important to Papua New Guineans' own understandings of their cultures and their past. Finally, the new ordinance introduced the idea of a national interest in the protection of cultural objects at the beginning of the last decade of Australian colonial rule.

\section{The National Cultural Property (Preservation) Act}

\section{At Independence, the National Cultural Property (Preservation)} Ordinance became the National Cultural Property (Preservation) Act. The Act explicitly states that the administration of the Act is the responsibility of the Trustees of the National Museum. The Act (Section 2) defines national cultural property as

any property, movable or immovable, of particular importance to the cultural heritage of the country, and in particular (but without limiting the generality of the foregoing) includes-any object, natural or artificial, used for, or made or adapted for use for, any purpose connected with the traditional cultural life of any of the peoples of the country, past or present.

The definition of national cultural property is thus intentionally broad and general. This is important both because of the cultural diversity of Papua New Guinea-and hence the existence of multiple cultural heritages instead of a single cultural heritage-and because the objects of cultural property covered by the Act are individually unique. In addition to national cultural property, the Act also divides cultural objects into two other categories-proclaimed cultural property and objects not covered by the provisions of the Act. 


\section{Proclaimed cultural property}

The most restricted category of cultural property defined by the National Cultural Property (Preservation) Act is 'proclaimed cultural property'. Under Section 4 of the Act, the Head of State, acting on advice from the Trustees of the National Museum, may declare any object or category of objects to be proclaimed cultural property.

To date, about 400 individual objects have been gazetted as proclaimed cultural property. As required under Section 12 of the Act, the National Museum, on behalf of the Trustees, maintains a register of these objects which cannot legally be acquired or moved without the permission of the Trustees. People who have possession or control of objects that are proclaimed cultural property must legally notify the Trustees if there is any change in the situation or condition of the objects.

Some of these objects of proclaimed cultural property are now in the National Museum, but the majority are located in villages where villagers consider them to be important cultural objects. Because the protection of these objects depends on cooperation between the National Museum and the people in the villages in which the objects are located, the National Museum uses the Act as much as possible to assist villagers to protect those objects which they want to protect. This is in contrast with the colonial period and the period immediately following Independence when government officers recommended objects for gazettal primarily on the basis of an object's artistic or historical value from a European perspective. At the same time, the National Museum tries to monitor community attitudes since the meanings of objects may change over time. Thus objects that a community once wanted to protect may become less important and may even become objects that the community wants to dispose of.

Several categories of objects (as opposed to particular objects) have also been gazetted as proclaimed cultural property-human remains of any kind, traditional funerary objects, carvings or engravings on stone, carvings or engravings made wholly or partly with stone tools, paintings or carvings on rocks or in caves, ancient pottery and relics of historical or antiquarian interest. In addition, any of the following categories of objects are proclaimed cultural property if they were made before 31 December 1960 - parts of ceremonial houses, carved garamuts and garamut sticks, carved wooden masks, masks of any material other than wood, carved wooden shields, carved wooden ancestral boards, musical 
instruments and carved wooden figures. It is important to note that while the Act prohibits both the acquisition and exporting of objects in these categories if they were made before the end of 1960 , this does not mean that objects made later are automatically acceptable exports. Objects made after 1960 may still be prohibited exports because of their importance to the cultural heritage of the country or the cultural heritage of a particular group of citizens.

\section{Objects exempted from the Act}

At the other end of the continuum from proclaimed cultural property are those categories of objects which are specifically exempted from the provisions of the National Cultural Property (Preservation) Act. These mainly include objects that have been recently made for sale to tourists and artifact dealers. Most objects regularly purchased by tourists as souvenirs are included on the list of exempted categories of objects.

\section{National cultural property}

The third category of objects defined by the Act is national cultural property. Most cultural objects fall into this category. The Act defines national cultural property as any property of particular importance to the cultural heritage of the country, including any objects made or adapted for use in connection with the traditional cultural life of any of the peoples of the country. The Act thus allows for the protection of hybrid objects which are combinations of traditional and nontraditional materials. Objects as diverse as a garamut made in 1970, a lime gourd and spatula, a mask made in 1995 for the ordination of a priest and a piece of metal hafted as an adze for carving canoes are all national cultural property.

The Act gives the Trustees of the National Museum considerable power with respect to national cultural property. For example, they have the power to recommend to the Head of State that national cultural property - whether movable or immovable-should be compulsorily acquired, or that ownership of it should be prohibited or restricted.

The Trustees, or persons authorised by them, may enter and search any land, building, aircraft, vessel or vehicle in which there is reasonable cause to believe that there may be national cultural property. A person can be required to provide information about, or to produce for inspection, national cultural property in his or her control or possession. 
The Trustees and their representatives also have the power to seize and detain for examination any item of national cultural property. Anyone who hinders or obstructs the Trustees or their representatives in the exercise of these powers is guilty of an offence under the Act. Finally, people who wilfully damage, deface or destroy national cultural property are also guilty of an offence.

\section{Implementation and enforcement}

Under the National Cultural Property (Preservation) Act, a person exporting or removing from the country any item of national cultural property without the written consent of the Trustees of the National Museum is guilty of an offence. This permission is given in the form of an export permit or license to export. The decision about whether an object of national cultural property should be allowed to leave the country is a decision for the Trustees of the National Museum who are also authorised to settle any disputes arising from the enforcement of the Act. The primary criterion used to make this decision is whether an object is important to the cultural heritage (or cultural heritages) of the country. Lesser criteria include age, rarity and whether the type of object is represented in the collections held by the National Museum.

On a day-to-day basis, the enforcement of the National Cultural Property (Preservation) Act, including the issuing of export permits, is carried out by staff at the National Museum. People who want an export permit must apply in writing and must either produce the objects that they want to export for inspection or provide clear photographs of the objects. The Museum reserves the right (given by the Act) to inspect objects in person. There is no charge for export permits, and most permits are issued within 24 hours after the application is received.

The cooperation of people in rural areas and provincial centres is vital to the enforcement efforts of the National Museum, and in most instances there is good cooperation from individuals and organisations. The Museum regularly receives reports from villagers, government officers and tourist operators about possible violations of the Act, which are investigated often in cooperation with police and customs officers at the district, provincial and national levels. Any item of national cultural property exported or attempted to be exported without the written permission of the Trustees is a prohibited export within the meaning of the Customs Act and so can be seized by the customs officers under the provisions of that Act. 
The main difficulties encountered by the National Museum in implementing the National Cultural Property (Preservation) Act lie in not having sufficient resources to enforce the Act and in the high prices that Papua New Guinean national cultural property fetches on the international art market. The adequate enforcement of legislation such as the National Cultural Property (Preservation) Act requires a significant commitment of time by Museum personnel.

The high value of Papua New Guinean national cultural property on the international art market has two effects. First, the National Museum is unable to compete to purchase such objects when they are offered for sale in other countries. Second, and more importantly, dealers and collectors are willing to take considerable risks to remove objects from the country illegally.

\section{International agreements}

The 1972 Convention Concerning the Protection of the World Cultural and Natural Heritage (often referred to as the World Heritage Convention) is the primary international agreement concerned with cultural heritage. Papua New Guinea recently acceded to this convention, which in the cultural arena seeks to protect only immovable cultural property such as monuments, groups of buildings and sites. The National Museum is currently taking the first steps in having two important archaeological sites added to the list of World Heritage sites. These are the Kuk archaeological site outside Mount Hagen, which was one of the earliest agricultural sites in the world, and archaeological sites on the Huon Terraces in Morobe Province, which contain the earliest evidence of human habitation on the island of New Guinea. In July 1997, the Director of the National Museum made a preliminary presentation concerning these two sites at a UNESCO meeting in Suva where possible World Heritage sites in the Pacific were reviewed.

The main international agreement on movable cultural property, as opposed to immovable cultural property, is the 1970 UNESCO Convention on the Means of Prohibiting and Preventing the Illicit Import, Export and Transfer of Ownership of Cultural Property. Papua New Guinea is not currently a signatory to this agreement. This convention recognises that states have an obligation to protect cultural property from illegal export, theft and destruction. It also recognises that the exchange of cultural property is important for cross-cultural 
understanding, and that the definition of cultural heritage is subjective and varies from culture to culture. Signatory states are permitted to declare exactly what forms of cultural property are to be protected (Ley 1991:19).

Signatories to the Convention on Cultural Property agree to oppose illicit traffic in cultural property in several ways, including creating inventories of cultural property, educating the general public, formulating appropriate laws and penalties, enforcing a system of import and export permits and assisting in returning illegally exported cultural property.

Opinions concerning the effectiveness of the Convention on Cultural Property vary considerably. In a 1991 report on a ministerial review of cultural heritage legislation in Australia, it was stated that the Convention 'is widely regarded as the most important agreement relating to the traffic in cultural property' (Ley 1991:18). A more recent 1996 review of the Convention, however, stated that ' $[t]$ he extent to which the convention has succeeded in stemming the flow of cultural property to dealers in ethnic artworks is not clear and may be minimal' (Posey and Dutfield 1996:115). Those who argue that the Convention is relatively ineffective point to the fact that it relies on member states to introduce their own legislation and to police it effectively, and to the fact that a number of states that are important in the art importing business, including Britain, France, Germany and Switzerland, have not acceded (Ley 1991:19-20).

\section{Conclusion}

Cultural objects are complex manifestations of creativity, knowledge and social relations, and cultural property is a form of intellectual property. For Papua New Guinea, legislation protecting cultural property has existed since 1913. At present, the movement and, in some instances, the ownership of cultural property is governed by the National Cultural Property (Preservation) Act which is administered by the Trustees of the National Museum.

While using the language of property, the National Cultural Property Act restricts the transaction of certain objects and categories of objects by asserting national interest-they are important to the collective history and identity of the whole people, the citizens, of the country. The history of the development of the Act has been toward allowing local people to say what objects they think are important and which 
they want to protect. The government, by acting to protect objects of national cultural property, acts on behalf of a plurality of people. In taking account of local concerns, it argues for the importance of certain objects beyond the local level, for the importance of objects for the nation as a whole.

Debates about intellectual property, including cultural property, must consider not only the protection of people's rights over property and over the products of their creativity and labour. They also need to consider whether the capitalist concept of alienable property-of objects and things that can be freely bought and sold-is appropriate for all types of objects and cultural intangibles such as songs, dances and oral traditions. These debates must take account of the complexity and social embeddedness of objects, of the difficulty of saying where an object or an intangible aspect of culture begins and ends. They need to take account of what people in the Middle Fly would describe as the personin-the-object. 


\section{Notes}

1 In common English usage, a relic is a survival from the past or something of religious reverence.

2 For example, questions such as whether a steel axe head-hafted in the same way that stone axes were hafted-constituted a Papuan tool were not considered.

3 The historical value of an object was, of course, something for the colonial government rather than the local people to determine.

4 The items considered Papuan antiquities and listed in the regulation included: carvings, paintings or drawings on wood, bamboo, coconut palm, stone or bone (including skulls); implements, weapons, tools and ornaments made of the same materials; shell ornaments and carvings on shell; ceremonial canoes; drawings or representations of animals on pottery; garments made of feathers; feather headdresses exceeding two feet in length; fossilised bone; stuffed human heads; any dried or preserved specimen or part of a human body; and armour of any kind of material.

5 The categories of objects exempted were as follows: all articles consisting of common types of disc clubs, spears, miniature houses, model canoes, bows, arrows, nets, native cloth, kaipas (net bags), wooden clubs, belts, shields, bamboo pipes (baubaus), baskets, combs, spoons, wristlets, fishing sticks, walking sticks and matting.

6 The purpose of collecting, and in particular the distinction between the collecting of curios by artifact dealers and scientific collecting, was taken up in 1923 by the government anthropologist in Papua, F.E. Williams (1923). 


\section{6 \\ Ownership of ideas and things \\ a case study of the politics of the Kuk prehistoric site}

\section{John D Muke}

They have used me and made so much money out of me and now, you come here to protect the things that will make others become famous in future. You also come to sell my ideas and things. What have you given back to me? (Ongka, personal communication 1994). ${ }^{1}$

Jack Golson came and we worked together in the ditches. He paid us for our labour but he took the knowledge to Australia. He did not leave it here with us. You want us to look after these things of the ancestors, but they are of value to the future. Now the Kawelka are short of land and have divided the blocks among themselves. It is hard for me to try and stop them from destroying the prehistoric sites. You know when they have already made their gardens, they will ask you for money if you want to excavate on their land (Ru, personal communication 1997). ${ }^{2}$

In Papua New Guinea today, natural resources are seen as property to be exploited. Cultural resources are increasingly equated with natural resources and intellectual property rights provide an avenue for them, too, to be exploited. Whereas natural resources are an embodiment of nature, cultural resources are products of human society. Papua New Guinea's unique cultural heritage includes social practices and material traces that remind present generations of their origins and the world of their ancestors. It also includes an archaeological record that goes beyond the threshold of human memory, extending over 50,000 years of human occupation.

Understandings about the ownership of ideas and things among the people of Papua New Guinea affect the way this cultural heritage is treated today. Changing opportunities to market culture and changing perceptions of 
outsiders have created new expectations among the owners and custodians of cultural artifacts and knowledge. These expectations must influence approaches to the preservation and promotion of Papua New Guinean cultural heritage, but they should also inform debates about intellectual property. Intellectual property rights that serve to commodify culture even further may not be in the long-term interests of the owners of cultural knowledge, or those of the country as a whole.

This chapter discusses people's attitudes towards the ownership of ideas and things. The word ownership is chosen in preference to intellectual property rights. For some people, the word intelligence is associated with success in the formal education system. Intellectual property rights can therefore be seen as rights only accruing to a few selfish members of the educated élite. This poses a question worth considering - what are the intellectual property rights of the residents of Morata settlement in Port Moresby?

The quotations at the beginning of this chapter were recorded during conversations with two prominent local leaders from Kuk historical site in Western Highlands Province. This chapter considers issues of the ownership of ideas and things from the perspective of the makers of these two statements. At the heart of the issues are the relationships between the leaders of Kuk and the academics who came to study the site. In discussing these relationships, I wish to acknowledge that I have benefited from continued interaction with the leaders of this area-through constant dialogue - and with the academics who have studied it - through reading their writings. I am particularly indebted to the writings of Andrew Strathern (1985), Marilyn Strathern (1996) and Jack Golson $(1977,1982)$.

The chapter is written from a number of overlapping perspectives-as a member of a neighbouring community, as a researcher trained in an analytical framework and as an intellectual seeking to explore the concept of intellectual property rights. It begins with an outline of the background to the debate about the Kuk site, and then considers in turn the issues raised by the statements of the two informants.

\section{Background to the Kuk debate}

In the late 1960s, the Department of Primary Industry purchased 700 acres of swamp in the Kuk basin from its owners, the Kawelka tribe, to establish a tea plantation, which later became an agricultural research station. Early in its history, Jim Allen, recently appointed as a lecturer in prehistory in the Department of Anthropology and Sociology at the new University of Papua 
New Guinea, visited the station and saw the sort of evidence for ancient swamp drainage and cultivation which Jack Golson of the Australian National University had previously reported for the Warrawau tea plantation (Allen 1970; Golson et al. 1967).

The Kuk site has since acquired international significance as a result of the work of Golson, who, in collaboration with several other scientists, has dedicated much of his scholarly life to the reconstruction of the gardening systems. Six major systems were revealed-9,000 BP, 6,000-5,500 BP, 4,000-2,500 BP, 2,000-1,200 BP, 400-250 BP and 250-100 BP. 3 Microscopic parts of plants growing in the swamp or carried into it by wind or water from outside gave information about forest, grassland, climate and human cultures. Wooden artifacts (wooden spades and digging sticks) recovered from permanently waterlogged conditions provided information about the kind of technology used in the management of wet and dry land cultivations (Golson 1977, 1982).

Kuk is now known throughout the world as one of the earliest centres of independent innovation of agriculture, regularly acknowledged in standard introductory textbooks (Fagan 1980:198, 1990:224-6; Renfrew and Bahn 1991:228). Part of the significance of the site lies in the tangible evidence it provides of a sense of identity and habitation that equal the history of human occupation anywhere in the world (Groube et al. 1986). These revelations not only provide an important piece of the jigsaw about human history-they also help to debunk the myths about small-scale tribal societies that are embedded in phrases like 'primitive' and 'stone age'.

\section{The death of scientific interest in Kuk}

One of the reasons why the Kuk site is so well known, and has provided so much evidence of significance, is that issues of a political nature did not impede nearly 20 years of scientific research. There was no conflict of interest between the local landowners and the efforts by academics and authorities to study and protect this ancient cultural resource. The site was located on a property belonging to the state. With a series of understanding station managers, it was protected from destruction by the fact that the eastern half of the station was not brought into immediate cultivation.

Towards the end of 1990 , it was decided to close the Kuk station. A number of reasons appear to have prompted this, including declining government revenue as a result of the Panguna copper mine closure, and concerns about the safety of staff. Staff of the provincial government of the 
Western Highlands attempted to negotiate with local landowners a way of mothballing the property until operations could start up again. It was proposed that provincial public servants should occupy the vacated houses, and part of the rent collected should go back to the villagers. A general agreement was reached among the landowners to open a passbook account to receive the rent. However, misuse of the account led to a dispute among the Kawelka, who in turn harassed the public servants. This led to the total abandonment of the station. The residential compound was subsequently occupied by the landowners themselves.

In November 1993, Golson and I, along with a team of archaeology students, went to Kuk to meet with the local landowners of the now abandoned station, taking with us officers from the Division of Culture and Tourism and the Division of Agriculture and Livestock (formerly the Division of Primary Industry) of the Western Highlands Provincial Government. The objective was to discuss plans for future land use and to seek ways of protecting and preserving parts of the Kuk archaeological records as national heritage (Strathern and Stewart 1998). Golson and I returned in June 1994 to see how things were developing on the ground at Kuk, and again in May 1997, after the continued inactivity of the Division of Agriculture and Livestock had led to the land being taken over by the traditional owners. I myself made annual trips to the site, during which a number of lengthy discussions were held about its cultural importance, not only to Papua New Guinea but to the history of humanity.

The statements from Ongka and $\mathrm{Ru}$ set out above emerged from these conversations. They address issues of the ownership of ideas and things. In the following parts of the chapter I analyse Ongka's statement in the context of reciprocity of knowledge and Ru's comments in relationship to the ownership of things.

\section{Ownership of knowledge}

Kawelka Ongka developed a long-term relationship with the archaeologists who came to work at the Kuk site, as he had done previously with social anthropologists, especially Andrew Strathern, who were independently engaged in studies of the Kawelka community. He appeared in four films and published his own autobiography, translated by Andrew Strathern at his behest (Ongka 1979). The products of this relationship - exchanges of ideas, information and materials-ensured both fame for the researchers and an increase in Ongka's own standing within his culture. Yet notwithstanding this, Onkga's comments question the role of anthropologists in the 
production of knowledge about Kuk and the benefits that should flow to him as an informant.

\section{Responses to foreign researchers in Papua New Guinea}

The discipline of anthropology has a long history of involvement in Papua New Guinea. Anthropology developed at a time when few parts of the world had been unaffected by European colonisation. Papua New Guinea's fame in the anthropological world during the first half of the twentieth century stemmed from perceptions that it was one of the last untouched frontiers for anthropologists.

The exposure of tribal groups in Papua New Guinea to research work has generated considerable criticism. Andrew Strathern (1985) has usefully summarised some of these criticisms and many of them are addressed in his writings. They include

- anthropological writing demeans the indigenous communities as primitive

- anthropology has been intimately linked to the colonial order

- knowledge gained through research is exploited in the form of books and articles

- the field has no practical value.

The proposition that anthropology is linked to the colonial order is lent some weight by historical circumstance. Anthropology has traditionally been an avenue for the West to express its views of other cultures. Non-literate and non-industrial 'primitive' cultures, organised on a small scale, were contrasted with the complexities of the modern industrial world. As such, early anthropology provided a scientific justification for colonial domination by European powers.

Strathern argues that although anthropology may have had Eurocentric roots, by 1950 its major contribution was to promote decolonisation. Anthropologists did not assist the colonial regimes directly, and colonials generally treated them as outsiders in the European network. Remarking on his own role, Strathern (1985:171) commented: 'I did not exactly feel, then, that I was at the very hub of the wheel of colonialism at this time'. Still the fact remains that he came into contact with the natives as a European first.

For if it is true that no production of knowledge in the human sciences can ever ignore or disclaim its author's involvement as a human subject in his own circumstances, then it must also be true that for a European or American studying the Orient [the Melpa] there can be no disclaiming the main circumstances of his actuality: that he comes up against the Orient [the Melpa] as a European or American first, as an individual second (Said 1991:11). 
Over the years, indigenous and foreign scholars have debated these issues. A number of indigenous academics and others have questioned the rationale, justification and benefits to be gained from researching tribal communities, including Morauta (1979) and Talyaga (1974). Concerns about exploitation feature prominently among them. On this issue too, Strathern (1985) offers an opposing viewpoint. He argues that it is usually educated Papua New Guineans who dislike the idea of PhDs (cast in this context as commodities) being manufactured from the raw material of knowledge about traditional societies. He labels this kind of rationality as 'zero sum thinking', and argues that 'a $\mathrm{PhD}$ should not simply be seen as an absolute gain to the person who obtains it', because 'a thesis can be written so as to be interesting to those who are its subjects' (Strathern 1985:174). The pontification by national élites is an unnecessary charge, he says, and urges them to team up with expatriate colleagues to concentrate on salvage anthropology, otherwise the knowledge might be lost forever.

However, the comments about intellectual property made by Ongka and $\mathrm{Ru}$ are not those of educated élites, but come from the people who, Strathern says, know the situation and base their comments on 'perceived reciprocity or the lack of it' (Strathern 1985:173). Strathern defends his research work on the basis that people living in Mt Hagen think it is a good thing I had written so many books and articles because these carried their own names outwards, and also brought many visitors back to them' (Strathern 1985:173). If this is so, why did Ongka say 'you come here to make money out of my ideas and things'?

\section{Reciprocity: the cultural context of knowledge}

Ongka's perspective is that his intellectual creativity represents an investment in the future, like a seed. If it is successful, and the tree that grows from his seed bears fruit, then those who have benefited from the fruit will be indebted to him as the source person. This corresponds to the Wahgi concept of reproductive kinship incorporating roots (uncles), base (mother) and transplants. In this context, transplants are always indebted to their source people for their own wellbeing. From Ongka's perspective, it was through him as a source person that others have attained fame, status and wealth (Muke 1992; O'Hanlon and Frankland 1986). Therefore researchers were indebted to him.

Marilyn Strathern (1996:23) puts it this way: 'Like wind-borne seeds success (texts) is measured by the numbers of sites at which it grows'. Ongka felt that he was an equal partner in the sowing of seeds-or, to use 
Marilyn Strathern's phrase, the 'dispersal of knowledge'-and he had high expectations of an obligation to receive at a later stage. In one sense therefore, the concept of originator that is familiar in an intellectual property context finds an unlikely parallel with a society based on exchange mechanisms. Yet, in the context of ongoing reciprocity, it can be difficult to distinguish who is the producer of the knowledge that is the useable product.

\section{Attitudes to researchers in the Wahgi}

When Ongka was a young boy, there were very few anthropological records relating to the Hageners of the Wahgi Valley, where the Kuk basin is located. Early descriptions of its society were made by missionaries and patrol officers entering the region after it was opened up to colonial exploration in the 1930 s. During the 1970 s, it was hardly possible to keep abreast of research findings relating to the Central Highlands of Papua New Guinea (Brown 1978:264). By the 1980 s, there were few peoples and areas that remained unstudied; several had been studied more than once. Researchers began to turn their attention elsewhere, perhaps in recognition that the Highlands, once a region of exciting anthropological prospect, was finally a bit 'overexposed' (Feil 1987:2).

Ongka was part of the generation in which too much anthropology was done. For this reason it is intriguing that he directed his questions about the use of knowledge not to those he had worked with, but to myself, a thirdwave anthropologist (or rather, a first-wave native studying himself). Perhaps Ongka was aware from the beginning that he was involved in the production of knowledge that had the potential to be created and transformed into something else. Marilyn Strathern (1996) says that potential becomes an asset, and establishing intellectual property is one way of securing control over the potential life of creative ideas with reference to both their production and their future.

In the Highlands, the politics of reciprocity govern expectations about social relations. The giving of a gift creates the potential to return something at a later stage, whether the value inherent in the gift is higher or lower than the previous gift which it reciprocates. If he knowingly accepted the way (he thinks) he was exploited, then Ongka probably did so because he felt himself to be in a situation in which the rules of perceived reciprocity applied.

The reason why knowledge is now perceived to have been stolen may lie in the way the inhabitants of the Wahgi perceive white men 
(Connolly and Anderson 1987). The Hageners perceived Europeans as 'manifestations of light-skinned sky beings... [who were] the ultimate source behind the power of social groups to reproduce themselves' (Strathern 1984:20). Despite Andrew Strathern's argument that his entry into the Wahgi Valley had nothing to do with the process of colonisation, but rather coincided with the process of decolonisation, it is nevertheless true that, as a European, he would have been credited with being part of the 'origin people' (in Melpa pulk-wamb), the true owners of exotic material items-steel, clothes, valua-bles, food and equipment. The class and ideological differences among the Europeans may not have been apparent to the Hageners. For them, white men all came from the same tribe. The Hagen ideas about perceived recip-rocity enabled Ongka to place Strathern in the position of a source person. $\mathrm{He}$ may have rationalised that through himself as the potential customer, recipient or 'path person', Western wealth would be channelled, reproduced, embedded and redistributed in the Kawelka sociopolitical settings.

An important factor about reciprocity is that it involves interpersonal relations between individuals who are expected to place themselves symmetrically; at birth they are equals and they engage in exchanges as equal partners. For the duration of this relationship, as they exchange information, ideas, food, material wealth and so forth, the role of 'originator-of-theconcept' shifts between a network of credit and debt relations. A credit is created when one gives gifts in the form of ideas, spiritual blessings, transferring of divine planting substances, daughters in marriage and so forth. The recipient must feel compelled to make a return at a later stage but not necessarily to the exact value-rather the aim is to cement the continuation of an existing social relationship. The original donor may feel that the exact value of the initial gift is not matched by the recipient but this really does not matter, so long as one gets something in return for previous debts. Some credit-debit relations are short-term; others, like the inheritance of divine substances, carry over several generations. A relationship between the scholar and the informant may have ended when the former completed the fieldwork, but the informant would still have an expectation about sharing in the products of the scholarship.

This may be one of the reasons why Ongka featured in four films and was the subject of several books, whereby the notion of stealing ideas and things became only secondary, but could be activated if positive relations turned into negative reciprocity. He may have expected that the scholars who worked with him would ensure he received returns from the products of 'useable knowledge'. 


\section{Relationships between researchers and subjects}

It is extremely difficult for researchers to maintain long-term relationships with their informants because of 'the demands of their career, family, and society' (Strathern 1985:173).

Outside the context of the fieldwork interaction, the relationship between the researcher and the subject changes. Taken from this perspective, the relationship can be usefully analysed using two of the three property ownership categories suggested by Marilyn Strathern (1996). I have recontextualised them as different levels of reciprocity: the originator of the products of collective life (cultural property rights) and the creator-producer of the products of useable knowledge (intellectual property rights).

The subject of research may have earnestly believed that he had found a new partner of equivalence who came from the source of the exotic items of wealth-pulk wamb (origin, roots or source people). However, what the subject did not know is that his new exchange partner had concealed his background, unconsciously or otherwise, and assumed a role of equivalence with the natives around him. Within his own culture, the researcher was born into an unequal position (lower or upper class and so on), and competes with others in a learning institution. His adventure into the Wahgi, for example, is an indication that he had successfully surpassed his own colleagues, and reached a level of success that entitled him to enjoy the fruits of his intellectual labour.

Behind this presumed reciprocity, the natives were unaware that these strangers felt free to use alien categories-- the first betrayal of the principle of equivalence- to record and observe their lives. The researchers would look beyond the proverbs, parabolic expressions, rhetorical devices, pointed anecdotes and so forth, but instead of finding individuals in personal relationships, would look for the underlying structures and functions of their actions.

While Ongka and the researchers may have talked at length, in the end he was only a useful resource person - an object- to which preconceived Western notions of empirical research were applied in order to separate him as an individual from the creative manifestations of himself and the behaviour associated with these manfiestations.

\section{Ownership of books and notebooks}

When the fieldwork season was over, the symmetrical relationships between the researchers and informants effectively came to an end. While the informants continued the ordinary aspects of their lives, the 
researchers went away with notebooks filled with observed primary data which would help them establish themselves in their own culture as members of the academic tribal community. The relationships they had left behind had been replaced instead by an expectation on the part of the informants about the nature of their future relationship.

Perhaps the greatest promise of the future-or obligation to return a gift-lies in the writing of books and articles. Obviously a book is of no immediate benefit to the studied community, unless the children of the informants learn to speak the language in which it is written. It is the writer who obtains ownership (through copyright) of the products of exchanged knowledge, because a text book is an object, like an archaeological artifact. Because these are tangible products, Ongka's claims of ownership are discredited. He may be the source, the originator of ideas-in much the same way as he credited the Europeans (or more specifically Strathern) as the source of European items - but he does not control the product as his property. Because his ideas are intangible he cannot prove ownership in a specific way.

The distinction between intangible ideas and the tangible products of their expression becomes less clear in the case of primary data. If Ongka does not have a stake in the books, what about the material contained in anthropological notebooks before it leaves an indigenous community? The notebooks are the property of the researcher and the primary data in itself is not valuable. The material is more a potential asset-like technology that transforms ideas into a visible form-and it is the creativity of the researcher that transforms it into a product that may or may not generate future returns. However, a book is also an indirect reflection of the relationship between the researchers and informants (and others). If the researchers are sponsored by academic institutions, those bodies may claim ownership of the product, or at least the researchers are obliged to make some return payments.

Marilyn Strathern says that, in order for a product to be of benefit, it has to meet contemporary demands. In most cases, books do not make money, and the ideas contained in such products have to travel along networks, the 'seeds of dispersed knowledge', so that they can grow in a number of sites. To establish a relationship between a producer and a product, the text-asproperty must be identified as originating from the native source. Once the product (text) is distanced from the source, the cultural knowledge comes to be identified with the writers of the text. Arguably, Marilyn Strathern's distinction between the products of collective life and products of useable 
knowledge parallels the separation between scholars and natives. In this regard, it is suggested that Ongka's claims of ownership rest upon the concept of control of cultural knowledge as products of collective liferecognisable objects (culture) and recognisable claims (identity). The validity of this proposal is supported by the preamble of the Constitution of Papua New Guinea, which says that we 'pay homage to the memory of our ancestors-the source of our strength and origin of our combined heritage' and 'acknowledge the worthy customs and traditional wisdoms of our people', and for Ongka it provides some basis for the claim of ownership of transmissibility of cultural knowledge over time.

\section{A bottle of kerosene}

Ongka did teach me one lesson. It is that we, the natives, have no way of evaluating outsiders and their involvement in our affairs, or what it means for our relationships with them (which take place within our own social setting) that they have associations, beliefs and social positions as members of another society (cf. Said 1991:10).

Until recently, those studied by anthropologists have accepted passively the right of outsiders to speak for them from an outside, a European, point of view. The cultures they created for us-for example, Melpa, Kuma and Chimbu - were manifestations of their own perceptions and personalities. For a period anthropological researchers enjoyed the hospitality of those they studied, but now people are increasingly aware of property ownership and no one can speak for Ongka, rather he spoke for himself to me in a plain language - the ownership of ideas and things.

However, one never can understand the politics of reciprocity; tomorrow Ongka may change his mind and say 'Andrew is a very nice person, because he helped me; and it is good that he wrote many books because other people know about us'. On one occasion Onkga coerced me to buy a bottle of kerosene for him, and he said 'now you know our ways better than them'. This is how intellectual property as an embodiment of exchanged ideas is embedded in social relations and should be appreciated among the community of intellectuals. If we are serious about intellectual property rights, we must have at least 700 indigenous anthropologists covering all the linguistic groupings in Papua New Guinea and producing their own materials; these groups may still cry out for the protection of their ideas from acts of intellectual theft. 


\section{Ownership of things}

\section{Exporting of knowledge}

Since the closure of the agricultural research station, the status of the Kuk historical site has been a cause for concern on the part of National Museum staff and archaeologists because of the takeover of the property by the original landowners and their subsequent use of the land. The threat of destruction has prompted appeals to larger organisations like the World Heritage Commission, for recognition of the site as one of importance to the history of humanity (Strathern and Stewart 1998). Jack Golson's concern about this issue brought him out of retirement to make several self-sponsored trips to Papua New Guinea (between 1994 and 1997).

The archaeological records at Kuk are situated within the boundaries of land owned by the Department of Agriculture and Livestock. For most of the period during which Kuk was intensively studied, this state ownership was assumed to provide a legitimate basis for the National Museum's custodianship of the cultural property. The closure of the Kuk station provided the foundation for the emergence of a third party interest-the original owners of Kuk. The politics of their new role is complicated by changing personal dynamics. The people with whom Jack Golson established relationships have gone into retirement from their positions of influence, and have been replaced by their children, and others, like $\mathrm{Ru}$, who participated in the excavations as a young man, have assumed positions of influence, wealth and prestige. They have a different view of their relationships with government and with researchers. It may be that some of them were instrumental in forcing the abandonment of the station and obstructing the use of buildings by the provincial authorities.

$\mathrm{Ru}$ is an important indigenous scholar who, like Ongka, featured in several films (Nairn, Strathern and Ongka 1983) and wrote an autobiography (also with the help of Andrew Strathern). Ru's comments set out at the beginning of this chapter were recorded three years after the first village meeting in November 1993. They were directed at Jack Golson, whose archaeological work on the prehistoric agricultural practices spanned a period of more than 20 years.

During the period of academic interest and study at Kuk, Ru associated with scholars operating within two quite different fields. Archaeological field methodology differs significantly from that of anthropology. It is primarily 
concerned with the remains of past societies, rather than tapping into the minds and thoughts of living people. As such, there need be little interaction between scholars and villagers about the production and maintenance of exchanged knowledge. In addition, this preoccupation with the past means that knowledge is gathered from observations of the physical landscape by researchers with different field expertise from that of anthropologists. Consequently, the product of useable knowledge comes to be identified closely with the scholars.

In contrast, anthropological researchers make repeated visits to the studied area and develop long term relations with the living communities. In the case of Kuk, they have effectively prevented any questioning about the ownership of knowledge by motivating the informants to write books about themselves. Practices of this kind were of little significance to the archaeologists who studied the site, since they were concerned with a period that went beyond the remembered history of the present occupants. Whereas Ru could discern some benefits from his social relationship with Andrew Strathern, he could see no similar benefit from his relationship with Golson. Ru may have felt that he gained recognition and status in anthropology but that he was left out in the production of archaeological knowledge. It was in this context that he made his remarks.

In what way could Jack Golson have left behind knowledge among the Kawelka? An anthropologist can contest Ongka's or Ru's comments by arguing that he or she gave something in exchange for the initial procurement of knowledge. A balance is maintained in which the informants and researchers both write books about themselves. Even if scholars had narrated the stories of the informants, the latter would still have gained the idea of a balance in the exchange of knowledge-equal participation in the production of a text. It does not matter if the scholars have written more books than the informants, since the ideals of reciprocity are based on balanced social relations rather than on exchanges of exact value.

The objects that are the archaeologist's 'informants'-like wooden digging sticks, pollen, sediments and structural features like ditches, fence posts and house sites-are mute. They do not talk in the way that Ongka and $\mathrm{Ru}$ did, but the archaeologists use rigorous scientific methods to make them speak for themselves. I suggested earlier that Ongka may have some rights to the notebooks of the anthropologist's field visits, since his community enabled their creation. When the informants die, taking with them the cultural knowledge recorded by the anthropologist, the notebooks may be-come the only record that exists of the cultural knowledge of earlier generations. 
The same cannot be said of archaeologists' field notes. Since the knowledge in them is gathered not from the minds of those long gone, but from the physical evidence they left behind, the archaeologist's notebooks are a simplified model or map to the knowledge; they are not the knowledge itself. The source of the knowledge is still buried in the swamps of Kuk. It is open to any Kawelka who may one day wish to follow the steps of Jack Golson and reproduce his or her own version of the human activities at Kuk swamp.

\section{Recovering old ground}

For a period after the closure of Kuk station, research work there abated. Following the meeting with the local landowners in late 1993, there were discussions about restarting archaeological fieldwork at the site. Meanwhile, human activity intensified in different parts of the abandoned station. However, most of the gardening activity was in the northeastern part, away from the southeastern blocks where most of the archaeological investigations had been carried out. An agreement was reached with the landowners that if there were plans to develop various plots within the station boundaries, the National Museum and the University of Papua New Guinea would be informed so as to allow for some salvage archaeological research.

What the researchers did not know until after the event was that the major clans of the Kawelka and Jika were moving across the boundaries of the old station in 1995 and 1996 and dividing the land among themselvesa process which might have been planned as early as 1990. The leaders of the Kawelka did not inform the researchers that this had taken place. It can be argued that, rather than hiding the truth, $\mathrm{Ru}$ took the view that it was none of the researchers' business. Although he concealed this information about the tribalisation of the state property, Ru kept his part of the deal. To him, four years was enough time for archaeologists to find money to do whatever they wanted. Since the blocks were the best land for garden activities and Ru's rivals staked claims by gardening in them, he may have been forced to make claims for himself. He thus took part in the rapid repossession of the property and its subdivision amongst selected family heads in 1996.

In November 1996, I visited Kuk with a Japanese television crew who were documenting aspects of early agriculture in Papua New Guinea. For the first time, I was able to inspect the southeastern part of the station where the main archaeological investigations had taken place in the 1970s. Since people had cleared the swamp vegetation to prepare gardens, I could see the 
traces of large prehistoric channels on the exposed surface; they were too deep to be affected by the shallow modern ditches, and were still waterlogged. The most disturbing observation was that the area of most archaeological interest, the area that ought to be protected, was under extensive cultivation, including some plots with coffee trees in various stages of maturity.

It was apparent that a clever strategy was being used to mask the gardening activities taking place on the repossessed land, and hence the encroachment on the locations of past archaeological investigations. By cultivating in areas which were invisible from nearby vantage points, the villagers had ensured that their activities would not be noticed. By the time I arrived at the end of 1996, most of the area previously subject to archaeological research was covered with food crops, vegetables, coffee trees and other trees like Casuarina. It appears that the Kawelka had been destroying the tangible evidence left by the previous owners (the state), and recreating a new domestic, personalised environment, in order to make a political statement about their ownership or reflect a legal claim to the control of the Kuk property. By destroying the tangible archaeological evidence that might provide a source that could stop them from owning the land (Muke 1998; Moutu 1978), the Kawelka placed the integrity of this internationally significant cultural heritage site at risk.

\section{The battlefield}

The Kuk station ground is like a traditional battlefield, where the imbalanced relations between two hostile groups are contested. In battle, the objective is not the permanent acquisition of the land of a defeated group, but the total destruction of the tangible evidence of their opponent's cultural activity within the territory. The idea is to turn the cultivated cultural landscape into a wild, barren no-man's territory. Upon the return to their own territory, the defeated group's initial settlements and gardening activities are concentrated on portions of territory away from the battle frontier. Slowly the settlements progress towards the battlefields, which are also closest to the striking positions of the opponents in the event of war. As soon as the bulk of the territory is cultivated, the group asserts its sociopolitical autonomy as a territorial unit. The lost ground is now legally theirs.

In their campaign to regain Kuk, Ru's group adopted a similar strategy. The state is the enemy whom they accuse of stealing their land through very 
cheap deals with their fathers and grandfathers. The hostilities of the early 1990 s, involving both a war of words and physical confrontations with government personnel, was a deliberate attempt to recolonise the property from the private ownership (of the state) to communal ownership (by the group). To prove that it is legally theirs, the Kawelka have to refer to the presence of their own culturally created tangible evidence on the landscape. How can they claim that the property is their own when the tangible evidence shows the hallmarks of the state's legitimate claim of property ownership?

The obvious strategy is to destroy most of the tangible records on the ground and then create new evidence which is aligned more towards the Kawelka's conceptions of a cultural landscape. This is partly what has been happening at Kuk over the last decade. The locals have systematically destroyed the tangible evidence left by the state. First they felled gum trees, occupied residential houses and offices and allowed pigs into the station, who bulldozed the land on top of the major drain networks. The next set of activities involved the establishment of initial gardens in the boundary zones between the state and customary lands, the division of the major blocks among the main sub-clans, the assertion of individual claims to plots within the main blocks, the replacement of food crops with cash crops (mainly coffee trees) and the construction of new houses.

At no stage of the domestication process initiated by the villagers did the state authorities counter-attack (for example, by sending in police to arrest and punish the trouble makers). When wokabaut sawmills were used to fell the gum trees, there was no intervention by Division of Agriculture and Livestock officers at the provincial level. The Division of Agriculture and Livestock's failure to move back into Kuk allowed the people to proceed to the final stages of legitimating their tribal ownership by the symbolic act of planting coffee trees, not only as economically significant but as permanent markers. They are tangible evidence which serve as a bargaining point for a large compensation demand from the people in the event of a claim of ownership by the state. The question now is, who owns the archaeological sites?

\section{Ownership of the Kuk site}

Ru's comments referred to money in terms of the fruits of his labour. He saw the fruits of that labour as the save (knowledge) that Golson wrote in his notebooks (without Ru's help) and took to Australia. He reproduced it 
there, and therefore its indirect benefits were enjoyed by others. Ru argues that, since Golson did not leave the knowledge behind, what remains in the soil should at least provide some benefit for the future generations of the community now there is a pressing need for land. Unless someone finds new land for the Kawelka, the Kuk property is theirs to keep.

Ironically, the tangible records from which the product of useable knowledge were created are still in the Kuk swamp. They have been buried there for many thousands of years, and the Kawellka are only the contemporary owners in a succession of previous owners of the Kuk swamp. In other words, Jack Golson only constructed his knowledge from that part of save that will always remain the property of the people. It can be argued (as is prescribed in the Australian Archaeological Association Code of Ethics) that 'the indigenous cultural heritage rightfully belongs to the indigenous descendants of that heritage except items given as personal gifts to non-indigenous people or given or sold to non-indigenous institutions' (Principle 5). If we apply this principle to the Kuk site, it is obvious that it remains the property of the traditional landowners. The ancestors left the traces behind, and present generations are the custodians of the places, tools and other resources used by their ancestors, as part of a single social continuum. From this perspective, the decision to protect, conserve and promote that aspect of the eroding culture must be in the hands of the indigenous people themselves.

Perhaps $\mathrm{Ru}$ is aware of this-it may not be a total coincidence that his plots are in the area that has received intensive archaeological attention. He has indicated that scientists may use his land free of charge, but will have to negotiate the rest with other landowners. The problem for archaeologists is that there are more than 50 owners of plots within the several blocks which are of interest to archaeology. A researcher would need to get permission from several individuals to do any kind of investigations. There are real questions now about how to protect the source of primary data for future returns, when it is in the ownership of so many individuals. It is cultural property which can bring direct and indirect benefits to the community. Unfortunately, the custodianship or ownership of cultural resource materials has become confused with the economic value of the swamps themselves, and the cash crops which can be grown within them. Only a significant effort at public education will change the attitude of the people on that issue. 


\section{Other cases}

As the idea of making money from land becomes more and more entrenched, the idea of selling objects of history from the surface of the ground becomes increasingly attractive. The emerging economic significance attached to items of cultural value raises issues about the loss of this cultural heritage. Kuk is only the most prominent of several cases of conflict between economic interest and cultural heritage that have arisen in the Wahgi region alone over recent years. These have involved the sale of objects of cultural significance, like stone axes and wooden spades discovered during drainage, and also claims for compensation to be paid before investigations could be made at the sites of such discoveries.

Particularly instructive is the case of Kana near Minj. I chose this area for my own investigations, because I thought that my personal connections might enable me to avoid the difficulties arising from the demands for money which had been encountered in other places. Several sites were located, and archaeological investigations were carried out at two of them. In 1993 and $1994 \mathrm{I} \mathrm{had} \mathrm{no} \mathrm{problems} \mathrm{gaining} \mathrm{access} \mathrm{to} \mathrm{the} \mathrm{Kana} \mathrm{site} \mathrm{(Muke}$ n.d.), partly because of a very good relationship with the plantation manager and partly because the coffee plantation was still seen as company property. However, by 1995 the loan was fully repaid and there was internal conflict among the local landowner groups. The company was dissolved and the coffee plantation was divided among the people themselves. The areas of specific archaeological interest have been divided among three families. While one family approved of the archaeological work in the area, the other demanded payments. Since 1995 I have been forced to make small financial contributions to the coffee owners in order to have access to this important site. Should this practice be discouraged or encouraged? This is a question to which I cannot provide any immediate answer.

\section{Conclusion}

Swamplands like those of the Wahgi Valley are a non-renewable resource, an ecological museum and an extraordinarily important relic in the cultural landscape library for scientific study. Because they are permanently waterlogged and too deep to be affected by the fluctuating water table, the swamps contain layers of humic organic deposits which are effectively sealed in a wet and airless environment. This favours their preservation, as long as the waterlogging is more or less permanent up to 
the time of exposure (Renfrew and Bahn 1991). The different phases of past swamp cultivation are registered at different levels of deposits by the superimposition of one layer of sediment on the other when the ditches of an earlier period of drained agriculture were filled in and covered over by sediment during a following period of abandonment (Golson 1982).

The challenge to preserve Kuk as a heritage site is contested by the traditional landowners. One has to seriously think about Ru's comments

It is hard for me to try and stop them from destroying the prehistoric sites. You know when they have already made their gardens, they will ask you for money if you want to excavate on their land.

Archaeologists are in an even more difficult position in trying to stop destruction at the national level. If $\mathrm{Ru}$ as a local leader cannot change the opinion of the owners, who can? The potential for selling archaeological heritage items or paying for access to the sites or sources of knowledge is becoming an enterprise activity in itself.

Coffee production is a high export income earner and Highlanders often refer to it as a pot of gold. They equate coffee with mineral resources. Compensation is awarded to landowners with mineral deposits, and people are aware that multinational companies pay for trees, bushes and anything of significance destroyed. Why should it not be the same for archaeological research in the swamplands? Such underlying rationality has influenced people to salvage genuine archaeological objects and sell them for cash, and they have demanded that archaeologists pay them first before they investigate the appearance of past cultural activities in these former swamps.

At present, it is only through goodwill and appreciation by the people themselves of the importance of cultural heritage that sites on the landscape are left undisturbed. Kuk is a valuable case study, and illustrates the wider problems of destruction of heritage. There are a number of ways to address these problems. They include introducing acts and policies on cultural property and heritage management, recommending World Heritage listing and conducting scientific investigations which would add a final chapter to Golson's version of the agricultural history of the Highlands. Unless efforts like these are made, the existence of Kuk (and sites of similar antiquity) will only be remembered on paper. 


\section{Notes}

1 This is not a direct quote. Rather, I have extracted and simplified the essential elements of this conversation.

2 Translated from the original Tok Pisin: Jack Golson i kam na mipela wok wantaim long baret. Em i baim mipela pinis. Tasol Jack $i$ kisim save i go long Australia. Em i no lusim wantaim mipela. Ol samting bilong tumbuna yu laik mipela lukautim, em tru samting bilong bihain. Nau ol Kawelka sot long graun na ol kisim block pinis. Em i hat tru long mi stopim ol long noken bakarapim ol baret bilong tumbuna. Yu save taim ol plantim kaikai pinis ol bai askim yu long baim ol sapos yu laik wok long graun bilong ol.

3 BP (before present) refers to a present which is fixed at 1950 in terms of radiocarbon dates. 


\section{7 \\ Stealing music from/in Papua New Guinea}

\section{Don Niles}

In contrast to the theft of intellectual, biological and most cultural properties, which occurs for the most part from Papua New Guinea, the theft of music works both ways - there are overseas thefts of Papua New Guinea music, but also Papua New Guinean thefts of overseas music. Any discussion of cultural property rights must take this into account. This chapter deliberately uses the words 'theft' and 'stealing'. In addition to being shorter and more dramatic than the phrase 'cultural property rights', it has more relevance, since it is only when people feel they have been wronged that questions of rights arise.

Traditional Papua New Guinean societies have ways of defining the rights of performance of music and dance, and also ways of dealing with transgressions. Yet because these systems seemingly function quite well, they are not a concern when it comes to the public voicing of questions about rights to performance. More of an issue is the theft of Papua New Guinean music by non-traditional groups. This generally falls into two areas - theft of traditional music by people from overseas and the theft of popular music (for example, stringband and powerband music) by other Papua New Guinean groups or overseas bands or organisations. Other thefts are possible, including the appropriation of traditional music by stringbands. Although this has not received the same level of publicity, it is certainly a concern raised by some elders when faced with the possibility of their sacred music being debased by a stringband.

Copyright concerns in Papua New Guinea have generally focused on the assumption that overseas artists are 'ripping off' local artists. While 
this has certainly happened, what is more common is the theft of overseas music by Papua New Guinean musicians. Both must be considered. The issue that has drawn the greatest attention and is the subject of most heated calls for copyright legislation is the unauthorised use of Papua New Guinean music by overseas groups, including bands, individuals and companies. The theft of Papua New Guinea music by other Papua New Guinean musicians has to be considered as well.

The use of Papua New Guinean music by overseas artists is nothing new-musicians have always sought new ideas from foreign music. In 1921, Emanuel Aarons published piano and voice arrangements of music recorded in Papua New Guinea by the Australian traveller Frank Hurley. The Australian composer Alfred Hill also made piano and voice arrangements of Papua New Guinean songs, although the results might not sound Papua New Guinean. The famous French composer Olivier Messiaen dedicated his piano composition Quatre études de rythme to the island of Papua, supposedly inspired by Papua New Guinean rhythms, and later incorporated Papua New Guinean birdsongs in one of his last orchestral works. More recently, Sr Duchesne Lavin has written many arrangements of Papua New Guinean songs, Mauricio Kagel has incorporated Papua New Guinean instruments in his compositions, Lanse Taudevin premiered his Cantata Buka in 1982 and Christopher Roberts wrote a Symphony bilong Papua. None of these compositions (see also the Annex) have raised much concern over the question of rights.

Questions about rights really only come into the spotlight when Papua New Guinean music is used-by popular musicians, in films or in other media - and the thieves have the potential to earn significant amounts of money. Papua New Guinean music has been misused in a variety of ways for differing commercial ventures. Complaints can be divided into three, occasionally overlapping categories.

\section{Use of materials without permission}

While all three categories concern lack of permission, the first category concerns the use of recordings, whether published or not, in new contexts or the commercial release of music previously not available commercially. In any case, the music is used without the permission of the collector or performer. Examples abound of such abuse within Papua New Guinea as one band complains about another band's theft of their songs, particularly after the latter has just released a cassette. Although most frequently applied to songs, theft of this kind is also reported for 
styles, for example, complaints that a certain stringband has copied the style of the Paramana Strangers or makes use of a bamboo band in an area where such ensembles are otherwise unknown.

While permission may be received for the reproduction of materials, the resulting product may be a curious mixture. For example, recordings from my own institute were used in a CD-ROM about the Maring people. However, while the colour photos and text on the CD-ROM do indeed concern the Maring, the recordings are of Enga music (Clarke 1995).

Unauthorised use also occurs in films. The Australian film To Have and To Hold uses Kaluli recordings made by anthropologist Steven Feld, apparently used without authorisation. The CD of the soundtrack lacks these examples, but does include a recording of Raun Raun Theatre, also allegedly used without permission (Raun Raun Theatre 1996: track 8), as well as recordings of Highlands flutes from an unknown source.

\section{Rerecording of a popular music song}

The rerecording of overseas popular music is a common practice in Papua New Guinea. Local groups simply record their version of a commercially released overseas hit. These are generally called 'cover versions' or simply 'covers'. Covers are an essential way of learning to make music, and sometimes the transformations of the original songs can be quite substantial, as in the wonderful reworking of Elvis's Always on My Mind by Gaba Kaluks (1985) in their song Vero.

The theft of popular Papua New Guinean songs by overseas artists is exemplified by Papua New Guinea's most well known and well publicised case of music theft-the theft of the Sanguma song Yalikoe by the Black Brothers, a band originally from Irian Jaya who resided in Papua New Guinea between 1979 and 1980. The band locally released a number of versions of Papua New Guinean pop songs, and then enjoyed a considerable success in Holland in 1982 with their version of the song (called Jalikoe), reportedly reaching third place on a European disco chart (Niles 1996). Sanguma's (1978) original version of Yalikoe is an arrangement of a traditional song from Maprik, performed by men to give them confidence and energy before going out to hunt. Sanguma's version demonstrates a conscious attempt to incorporate Papua New Guinea instruments and includes a garamut introduction. Further, there is a considerable difference between Sanguma's unaccompanied vocal section and that by the Black Brothers, which has been made without 
the use of Papua New Guinean instruments, creating a more international dance sound.

Although this was obviously straight theft by the Black Brothers without compensation to Sanguma, there does not seem to have been any discussion about what people from Maprik feel about the use of their traditional song as originally adopted by Sanguma.

\section{Manipulation of recordings}

A recording may be electronically manipulated (for example, by overdubbing or sampling) by musicians in the studio, creating a new sound. In contrast to the other two categories, this rarely occurs within Papua New Guinea. Overseas, it is an increasingly common type of music theft and Papua New Guinean music has been involved. In 1972, Pink Floyd mixed fragments of Papua New Guinean music for the sound track to a film called The Valley Obscured by Clouds (Pink Floyd 1972).

More recently, some of the Institute of Papua New Guinea Studies' own recordings have been used by a group in Germany called Miracle G(y)rlz, described on their World Wide Web home page as: 'Two guys born in Papua New Guinea with finnish [sic] parents and a drummer from Lithuania + melodic psycho-folk-punk-rock sculptures + hi-energy live-performance + intensity through 66 tracks!' (Miracle G(y)rlz nd). The Australian band Not Drowning, Waving began experimenting with their own recordings of Papua New Guinean music, eventually leading to their notable collaborations with George Telek (Not Drowning, Waving 1986, 1987, 1990a, 1990b, 1991a and 1991b). Finally, an Australian group, Drum Drum, has recently added tracks and modified recordings of Central and Manus music (Drum Drum 1996).

The most famous and commercially successful example of the manipulation of a recording of traditional music from the Pacific comes from Papua New Guinea's near neighbour, Solomon Islands. In 1969 a Swiss ethnomusicologist made recordings among the Baegu people on Malaita Island and released some of his recordings on a UNESCO disc in 1973 (Zemp 1973:track 8). Among them was a rorogwela lullaby, often sung not by the mother, but by the child's elder sister. The lyrics ask the baby not to cry because its parents are dead and no one else can hear the crying. The melody is familiar to many people as the origin of the track called Sweet Lullaby, released by Deep Forest in 1992.

In addition to being a major international hit, selling millions in the United States and Europe, and being nominated for a Grammy award, 
Deep Forest's song has been used in advertisements for Sony, Coca-Cola and Porsche. As has been well documented by the ethnomusicologist who originally recorded the work and others (Zemp 1996:44-9; Mills 1996:59-60; Feld 2000), Deep Forest (consisting of two Frenchmen) never received any permission for the use or manipulation of these recordings. No money has ever been received by UNESCO or by the ethnomusicologist who made the original recordings, and certainly no money has ever gone back to Afunakwa, the woman who sang the lullaby 23 years earlier.

\section{Responding to thefts}

These examples illustrate the types of theft that have occurred, and are likely to occur more commonly in the future, particularly as more individuals are able to make recordings and more recordings of Papua New Guinean music are available commercially. What can be done about this?

It has been suggested by many local musicians that Papua New Guinea must have a copyright law. In fact, Papua New Guinea does have a copyright law, although it is unenforceable. Reasons for this have been detailed by Nonggorr (1990; see also Niles 1992). But there are drawbacks too. If Papua New Guinea were to subscribe to international copyright legislation it would mean the end of cheap cassettes of overseas music. The price of a Michael Jackson, Abba or Don Williams cassette would probably triple, making them much too expensive for many consumers. Some may argue that such measures would benefit the local music industry, yet while there is no doubt of the popularity of some Papua New Guinean bands, would listeners be willing to abandon their favourite overseas bands in trade?

Traditional Papua New Guinean societies frequently had clear rules about ownership of music and dance and the procedures required to obtain the rights to perform it (Niles 1992). It is a feature of many groups within Papua New Guinea that they perform music that originates from outside their own area and this foreign origin is well acknowledged. This often accounts for the unintelligibility of the texts to present-day performers. Sometimes such music and dance is simply learned from neighbouring groups; perhaps more often, however, the rights to performance are purchased with traditional valuables, and the music is taught to the purchasers, ensuring that it is learnt properly. Much more is involved than just correct singing and dance movements- 
appropriate magic, taboos, decorations, rhythms and so on are essential. The buying and selling of rights to perform music seem to be particularly associated with the Mamose region, although examples could probably be found in all provinces.

Simply because there are mechanisms in place for the proper purchase of the rights of performance does not mean that thefts of music and dance do not take place. Traditional law provides ways to handle transgressions of this kind. While the Institute of Papua New Guinea Studies has received many general descriptions of such laws and the penalties associated with breaking them, to my knowledge there is nothing written in detail about how such systems operate.

Any group considering the preparation of laws for the protection of intellectual, biological and cultural rights should undertake a careful review of traditional counterparts. Unfortunately there is no detailed data of this kind, at least in the area of music. Documentation of these rules and practices is of prime importance. Perhaps in contrast to many of the other issues concerning intellectual property rights, there are traditional means of dealing with questions of ownership of music and dance. For this reason, it is important to know how these systems operate. Traditional Papua New Guinean societies have approached these issues in different ways. Knowledge will, hopefully, provide a basis for legislators to make informed suggestions about drafting laws to reflect these important precedents.

A comprehensive review of traditional intellectual property regimes will take time, but other steps can be taken now. Researchers (defined very broadly) should evaluate their own ethics when doing fieldwork in Papua New Guinea. While researchers must obviously be responsible for explaining the intended use of materials they collect, Papua New Guineans also need to be informed about these issues by someone other than researchers, so they can ask the right questions. This can be achieved by developing respect for and knowledge of the diversity of Papua New Guinean traditions, so creating a more informed populace. While people may still be eager to display their proud traditions, they need to be informed enough to enquire about possible uses of recordings or videos made of them. Politicians, as the controllers of money, need to be educated that cultural traditions are not something only to be praised at election time, but must be financially supported through the local institutions that engage in research on these traditions. The National Cultural Commission has taken important steps in recent years 
to promote Papua New Guinean cultures. It has also been exploring the use of cultural performances as a way of generating income for the practitioners themselves, thereby encouraging the maintenance of traditions.

While most researchers are very responsible, some are not. A requirement for research is that the results of research be sent back to appropriate institutions in Papua New Guinea. Some researchers fail to meet even this minimal requirement, much less return copies of their publications to the groups they have worked with. This must be monitored more closely by institutions responsible for the processing of research visas, especially the National Research Institute. Researchers must ensure that copies of every article, book, recording, film and video they produce are available in Papua New Guinea. If they do not deposit copies and cannot prove that they have done so, they should not be allowed into the country for further research until this situation is rectified.

Encouraging researchers to be ethically responsible is important, but researchers are usually not the greatest cause for concern. Rather, overseas bands looking for new sounds to sample or films needing to fill out their soundtrack with Papua New Guinean music are the most worrisome. As compact discs have become a standard medium and are relatively cheap, the sounds of music from different parts of the world have become more available than ever before. This is very exciting for any music lover, but it means that it is very easy to steal music from these kinds of recordings. Because of the huge numbers of recordings made, it is very difficult to know what has been done unless some commercial success is achieved by the thieves. Discussion needs to continue about whether Papua New Guinea should embrace international copyright conventions, given that these trends are likely to escalate in the future.

\section{Conclusion}

The importance of learning about traditional methods for the protection of cultural rights as a guide to future deliberations on this subject cannot be underestimated. It is also crucial to encourage education and awareness of what has occurred and to understand the possibilities of further occurences in the future. Making traditional music inaccessible to outsiders (local or overseas) deprives Papua New Guineans of an important symbol of their identity, yet this identity must be protected from distortion through ignorance, greed or lack of respect for these traditions. 


\section{Annex}

\section{Examples of Western compositions using Papua New Guinea} materials

Aarons, Emanuel, 1921. Pearls \& Savages; a cycle of Papuan melodies,

'Discovered' by Frank Hurley, W.H. Paling \& Co. Ltd., Sydney

[piano and voice].

Antill, John, 1958. New Guinea patrol.

Goodman, Isidore, 1944. New Guinea fantasy [for piano].

Hill, Alfred Francis, 1953. Alfred Hill's New Guinea Songs, Southern

Music Publishing Company, Sydney [piano and voice].

Kagel, Mauricio, 1971-72. Exotica [use of Papua New Guinea instruments].

Lavin, M. Duchesne, Sr., 1971. More Songs from Our Land, words by Sr.

M. Delia, Our Lady of the Sacred Heart Convent, Boroko.

_-, 1973a. Songs from Papua New Guinea Book 1, words by Sr. M.

Delia, Castle Music, St. Leonards.

—-, 1973b. Songs from Papua New Guinea Book 2, words by Sr. M. Delia, Castle Music, St. Leonards.

—-1975a. How Chaleu Became Chief; a musical play in one act for boys, based on a legend from Manus Island, words by Sr. M. Delia Donohoe. Castle Music, St. Leonards.

_- 1975b. Lotu; an English setting of the Catholic mass text, using the traditional music of Papua New Guinea (unpublished).

—, 1976a. Papua New Guinea; piano suite, J. Albert \& Son, Sydney.

_- 1976b. Singsing Tumbuna; traditional songs from Papua New Guinea, Rondor Music, Sydney.

—-1977a. Pacific Rhythm and Song: a selection from the local music of Papua New Guinea and neighbouring Pacific islands, arranged for recorders with percussion and chime bar accompaniment, Castle Music, St Leonards.

- 1977b. Theme with variations; an original PNG melody from Hus Island, Manus Island Province, Papua New Guinea, (unpublished). 
—, 1980. Sing Sing; six two part songs for Papua New Guinea, words by Sr. Delia Donahoe, Woomera Music, Reservoir, Victoria.

—, 1982. Kada Kakailai, Warner Brothers, Sydney.

—, 1990a. Missa To Rot, (unpublished).

- 1990b. Songs for a Happy Christmas, words by Sr. Dain Inglis and Sr. Delia Donahoe, Our Lady of the Sacred Heart Convent, Kensington.

—_ n.d. Malagene guvai (Come dance with us); an orchestral arrangement of selections of traditional music from Papua New Guinea (unpublished).

—, n.d. Six Papua New Guinea folk songs, (unpublished).

Messiaen, Olivier, 1949-50. Quatre études de rythme, [Dedicated to the Island of Papua], Durand, Paris.

—, 1987-91. Eclairs sur l'au-delà... [Illuminations of the Beyond...] [movement IV: White-throated gerygone (Gerygone olivacea); movement IX: New Guinea friarbird (Philemon buceroides)].

Roberts, Christopher, 1989. Symphony bilong Papua (unpublished) [for orchestra].

Sculthorpe, Peter, 1996. Simori, on Mere Bagatelles (Tall Poppies TP 080), played by Ian Munro, CD [piano pieces based on Papua New Guinea music].

Taudevin, Lansell, 1982. Cantata Buka, Lansell Taudevin, Boroko [orchestra and voices; recorded on NBC B 169]

-, 1983. Segaropa [poetry by Segg Putahu (1951-80)]. 


\section{8 \\ Plant genetic resources of Papua New Guinea some thoughts on intellectual property rights}

\section{RN Kambuou}

Over the last 20 years, there has been an increasing interest and enthusiasm for biodiversity prospecting and the development of natural products throughout the world. The exploration of biodiversity for commercially valuable genetic resources has the potential to encourage conservation and to provide economic benefits to developing countries and their local communities. However, despite the interest and rapidly increasing number of biodiversity prospectors, there are no clear national policies or legislation in place to govern and regulate biodiversity prospecting in Papua New Guinea.

This chapter discusses forms of law that might provide protection for intellectual property rights in plant genetic resources. It also discusses international undertakings and agreements that support individual countries' efforts to establish these kinds of protection.

\section{Plant genetic resources in Papua New Guinea}

It is estimated that Papua New Guinea contains more than 5 per cent of the world's total biodiversity, in less than 1 per cent of its land area. The country is also one of the world centres of diversification of traditional root and tuber crops, leafy vegetables, fruits and nuts, cooking bananas, underutilised food crops, sugarcane, medicinal plants, ornamental trees and timber trees. These are a rich and valuable resource that must be appropriately utilised and conserved for future generations. 
While this diversity is still largely intact, genetic erosion is taking place at an alarming rate in some places, mainly caused by urbanisation and increased lumbering, mining and agriculture activities. Mining and logging operations are changing the lifestyle of villages to that of a cash economy, and the indigenous diversity of crops is gradually being lost. The underutilised food crops and medicinal plant resources are disappearing as the older generations who are the users of these germplasms die, while the younger generations move to urban centres and mining sites. Valuable indigenous knowledge about the use of these plant varieties is vanishing with the older generation.

Papua New Guinea has approximately 38 million hectares of forest, spreading over 60 per cent of the country's land mass, of which more than 97 per cent is customarily owned by the indigenous inhabitants (Swartzendruber 1993). These forest habitats contain the country's valuable forest tree resources. Indigenous timber tree species include the Araucaria spp., Agathis spp., Eucalyptus spp., Acasia spp. and some exotic species such as Tectona grandis, Gmelina arborea and Ochroma lagopus.

There are more than 600 medicinal plants reportedly used in Papua New Guinea (Holdsworth 1977). Almost all these plants grow wild in their natural habitats and are collected by villagers whenever medical needs arise. The forest habitats of the country, particularly the rainforest areas, are rich storehouses for nearly 3,000 exotic orchid species, as many as 15,000 species of wild flowers and many species of ornamental shrubs, ferns, palms, mammals, birds, reptiles, insects and other organisms (Beehler 1992).

The production of staple food crops remains the most important agricultural activity for 85 per cent of the rural population. Subsistence farmers and local communities in Papua New Guinea follow complex farming systems. The main crops in the farming system are sweet potatoes, taro, yams, cassava, bananas and traditional leafy vegetables.

\section{Germplasm collections}

National ex situ collections of germplasm are held for major food crop species, fruits and nut tree species and some underutilised food crop species and ornamental plants-the latter being maintained in the National Botanical Gardens. Well over 7,000 accessions of 42 crop plant species were initially collected and are maintained in ex situ field collections. A recent report (Kambuou 1995) on freld collections reported that 1,474 accessions of 41 plant species are being maintained. 
Unfortunately, the rest of the collected germplasm has been lost because of funding constraints.

\section{Bioprospecting}

Advances in technology have enabled quick and inexpensive screening of wild products for potential agricultural, pharmaceutical and industrial development. Indigenous knowledge of bush medicine can lead researchers to discover potentially useful and naturally occurring medicinal compounds, and Papua New Guinea's isolated and culturally highly variable communities could provide valuable genetic information for the field of medicine. It is no surprise, therefore, that scientific and industrial demand for access to Papua New Guinea's genetic resources is increasing. Given the current trend, the value of Papua New Guinea's genetic resources for medicinal and industrial applications is likely to increase in the future. The time is now ripe for Papua New Guinea and the other island countries in the South Pacific region to take stock of these invaluable resources and start formulating policies to govern sustainable biodiversity prospecting.

\section{Export of germplasm from Papua New Guinea}

The germplasm of the 'noble cane' (Sacharum officinarum) of New Guinea is a good example of a valuable germplasm that was taken out of its centre of origin to help develop the sugarcane industry elsewhere. The earliest expedition to collect sugarcane was undertaken in 1875 . Since then several collecting trips have occurred. Some of these genetic materials are now held in the world collections run by the United States Department of Agriculture, Agricultural Research Service (USDA/ARS), while the fate of others, in particular those collected during earlier expeditions, are unknown.

Other crop resources that have been collected and taken out of the country include bananas (Musa spp.), various roots and tuber crops (Ipomoea batatas, Dioscorea spp., Colocasia esculenta), aibika (Abelmoschus manihot) and coconut (Cocos nucifera). Apart from the conservation and safe keeping of this germplasm in the regional or international genebanks, the level of utilisation remains unknown.

The National Botanical Gardens has encountered the illegal exportation of orchids in the past, and this will pose a major problem in the future if the law is not enforced. Some unconfirmed reports suggest 
that numerous orchids have been illegally exported on timber ships. To avoid the illegal exportation of such genetic resources, existing laws need to be strengthened. Long-term planning is needed to develop national policies on intellectual property rights and other rights, including those provided for in the International Undertaking on Plant Genetic Resources and the Convention on Biological Diversity.

\section{National laws and policies for protection of plant genetic resources}

Intellectual property law systems operating in many countries have conventionally provided five different types of intellectual property rights that might be used to protect plant genetic resources-patents, plant breeder rights, trademarks, copyright and trade secrets. The two mechanisms most suited to plant genetic resources are patents and plant breeder rights. More recently, there has been international debate about the development of a new form of protection for plant genetic resources, farmers' rights.

The Papua New Guinea legal system does not presently provide for any of these forms of protection, nor is there any national policy on intellectual property rights for plant genetic resources. However, there are other laws that relate to the protection of plants and animals, and general government policy on sustainable agricultural development and the preservation of natural resources and the environment, including the regulation of the export of native flora and fauna.

\section{Policy on agricultural resources}

Government policy on the development of agriculture reflects the following objectives

- facilitating the assessment of the environmental and social impact of agricultural development projects

- promoting sustainable and environmentally sound agricultural practices

- conservation, assessment and the effective use of genetic diversity of plant and animal species to help maintain and improve the agricultural environment

- research on the development of methods, including biological control methods, that will reduce the impact of agricultural pests, diseases and weeds 
- development of an institutional capacity to undertake regulation, monitoring and testing of agrochemicals and agricultural outputs

- maximum involvement of local people in all aspects of agricultural development and implementation of agricultural projects.

\section{Protection of indigenous flora}

There are several laws that provide protection for the flora of Papua New Guinea and prohibit the export of these resources. These include

- Fauna (Protection and Control) Act

- International Trade (Fauna and Flora) Act

- National Parks Act

- Forestry Act

- Quarantine Act

- Customs (Prohibited Export) and (Prohibited Import) Regulations. The Department of Environment and Conservation and the National Agriculture Quarantine and Inspection Authority are responsible for enforcing these laws through licensing systems that require wildlife export permits, Convention on International Trade in Endangered Species certificates and phytosanitary certificates for the export of plant material. These systems are intended to protect plant genetic resources for a variety of policy reasons. For example, Convention on International Trade in Endangered Species certificates are required as part of an international legal framework that protects endangered species threatened by international trade.

Although this legal framework is in place, the enforcement of these Acts and regulations is unsatisfactorily or ineffectively monitored. This has resulted in many valuable genetic materials leaving Papua New Guinea without proper permit procedures being followed.

\section{International undertakings and agreements}

\section{Convention on Biological Diversity}

Perhaps the most significant international instrument in terms of plant genetic resources is the Convention on Biological Diversity. A total of 157 nations (including Papua New Guinea) have signed the Convention and 65 countries ratified it at that time. The Convention on Biological Diversity is a framework agreement which is legally binding and came into force on 29 December 1993, having been signed by Papua New Guinea in 1992. It provides an international legal justification and a 
framework for the country to establish sovereign rights over its genetic resources.

The objectives of the Convention on Biological Diversity are the conservation of biological diversity and the sustainable use of its components. It promotes fair and equitable sharing of the benefits arising from the utilisation of genetic resources, including appropriate access to genetic resources, and the appropriate transfer of relevant technologies, taking into account all rights over those resources and technologies (Article 1). Article 1 effectively authorises nations to establish regimes to regulate access to their genetic resources.

The Convention on Biological Diversity also deals with the rights of indigenous communities. It directs parties to 'respect, preserve, and maintain knowledge, innovations, and practices of indigenous and local communities, embodying traditional lifestyles that are relevant for the conservation and sustainable use of biological diversity' (Article 8).

The most significant achievement of the Convention on Biological Diversity is the establishment of the concept of national sovereignty over resources. The concept of states' sovereign rights over natural resources has replaced the common heritage principle, and access to a country's genetic resources must be on mutually agreed terms and with the prior informed consent of the state owning the resources. Prior informed consent is an important aspect of any access agreement and any country declining to require prior informed consent risks uncontrolled and free access to its resources. However, the sovereign rights concept does not apply to the resources that are already in the international repositories, only to those materials located within a country's borders at the time the Convention came into force.

\section{International Undertaking on Plant Genetic Resources}

The purpose of the International Undertaking on Plant Genetic Resources is to ensure that germplasm of economic or social interest, particularly for agriculture, will be explored, preserved, evaluated and made available for plant breeding and scientific research purposes. The principle aim of this undertaking is to redefine the common heritage of mankind and plant genetic resources, including those created by modern techniques.

A number of amendments have been made to the Undertaking since 1983. In 1989, Resolution 5/89 was adopted. It redefined the concept of farmers' rights as rights arising from the past, present and future contributions of farmers in conserving, improving and making available 
plant genetic resources, particularly those in the centres of origin of diversity. The Undertaking also recognises the sovereign rights of countries over their plant genetic resources. The Undertaking gives the Commission on Plant Genetic Resources of the Food and Agriculture Organisation responsibility for monitoring developments with respect to intellectual property rights legislation, and assessing their implications for the Undertaking.

\section{Code of Conduct for Plant Germplasm Collection and Transfer}

The Code of Conduct for Plant Germplasm Collection and Transfer provides a practical approach to recognition of the sovereign rights of individual countries over the plant genetic resources in their territories. Based on this principle, conservation and continued availability of plant genetic resources is a common concern of mankind. In executing these rights, access to plant genetic resources should not be unduly restricted. The Code further contemplates the right of the permit issuing authority to grant or refuse a permit, and that collectors and sponsors should take into account the relevant national laws.

\section{Trade-Related Aspects of Intellectual Property Rights}

\section{Agreement}

The Trade-Related Aspects of Intellectual Property Rights Agreement is the most comprehensive international instrument on intellectual property ever negotiated and adopted. Under this Agreement, signatory countries are required to enact a variety of laws relating to intellectual property rights. These include laws protecting plant varieties, either by patents or by an effective sui generis system (such as plant breeder rights).

The Agreement increases protection and incentives for breeders and the biotechnology industry. Products or processes must be capable of industrial application before they can be eligible for patent protection. It can be argued that the Agreement supports and protects those activities that are multinational and trade-related in nature. Countries that are members of the International Union for the Protection of New Varieties of Plants comply with the Trade-Related Aspects of Intellectual Property Rights Agreement requirement of an effective sui generis system, and with advancement in technology, other countries will join and 
adopt the legislation of the International Union for the Protection of New Varieties of Plants.

The Trade-Related Aspects of Intellectual Property Rights Agreement can also be said to be in conflict with the Convention on Biological Diversity because it effectively provides incentives for those promoting uniformity in plant varieties, as opposed to incentives for in situ conservation of a diversity of genetic resources.

Countries that are bound by the Trade-Related Aspects of Intellectual Property Rights Agreement may decide to protect plant varieties either by means of patents or by a sui generis system. The possibility exists for combining both the patents and plant breeder right protection systems. The protection of plant varieties on the basis of patents may have important implications for access to genetic materials for the development of new materials and the on-farm use of seeds. For this reason, it is likely that many developing countries may consider the use of a sui generis system based on the concept of plant breeder rights.

\section{Intellectual property rights and local communities}

None of the international undertakings or agreements described above gives effective rights to local communities that are the rightful custodians of the rich genetic resources diversity in developing countries. It is important that these international agreements and undertakings recognise, realise and respect the rights of local communities who are the producers, innovators and custodians of the majority of genetic diversity. At present, these undertakings are narrow in scope, and effectively only recognise innovation and production when it takes place under the control of transnational corporations, and in conformity with the individualised context of the Western legal system.

Under the Convention on Biological Diversity, the rights of biodiversity are the sovereign rights of the nation states (Article 3). These rights can only exist if they are built on the rights of communities that have conserved and protected biodiversity within national territories for many decades. The people of Papua New Guinea lead a communal life in close relationship with nature and the environment that surrounds them. It is of utmost importance that the government stands behind the people in protecting biodiversity, especially the rich diversity in plant genetic resources. 


\section{Definitions of knowledge and creativity}

Intellectual property rights are intended to provide recognition and reward for intellectual creativity or to secure ownership over products of the human mind. However, knowledge and creativity have been so narrowly defined in the context of intellectual property rights that the creativity of nature and traditional knowledge systems have been ignored.

The intellectual property rights system that is being advocated under the Trade-Related Aspects of Intellectual Property Rights Agreement contains little scope for recognising innovation by millions of farmers and communities in developing countries, where biological diversity is concentrated and from where most knowledge of use has evolved. The governments of developing countries are being pressured to adopt immediately an intellectual property right system for plant genetic resources that serves only the narrow interests of commercial plant breeders in industrial countries. In developing new sui generis systems, developing country governments should focus on the rights of the farmers and local communities who have been the original innovators in the utilisation of plant genetic diversity.

\section{Limitations of patents and plant breeder rights}

Patents are the strongest form of intellectual property right protection. They give the inventor of a product or process exclusive monopoly rights over its commercialisation. The product or process must be new, useful and an improvement from the original art to qualify for a patent. When applied to plant genetic resources (as is the case in some countries) patent law does not allow farmers to reuse the seeds that they have obtained, and does not allow protected varieties to be used for further breeding, unless it is for research purposes with no commercial interest. The patent system varies from one country to another, because it is determined by each country's national legislation. These laws should be made flexible to cater for the needs of resource-poor farmers and farming communities in developing countries, who may not have the purchasing powers to pay for the seeds.

Plant breeder rights protect varieties which are new, distinct, uniform and stable. Breeder rights exclude non-authorised persons from using and multiplying propagating materials of protected varieties, but 
generally allow farmers to reuse, for the purpose of planting further crops, the seeds that they have obtained. Breeder rights, under a breeders' exemption, allow protected varieties to be used for further breeding, without the authorisation of the inventor of the variety. This is seen as an advantage in the field of plant improvement, as it is possible to freely exchange valuable germplasm.

The contributions made by the farmers and local communities in Papua New Guinea and in other developing countries in the conservation, selection and regeneration of plant genetic resources have been substantial, and it has been widely agreed that there should be some form of recognition for their invaluable efforts.

\section{Farmers' rights}

The concept of farmers' rights was originally proposed in 1983 as an amendment to the International Undertaking on Plant Genetic Resources of the Food and Agriculture Organisation. It is intended to provide a measure of counterbalance to formal intellectual property rights by providing a system of intellectual property rights tailored to the needs of farmers who have, over many generations, bred food crop varieties for their own use. Farmers' rights are based on the recognition of the intellectual creativity and innovative capacity of farmers. They are not assigned to specific varieties, types of plants or farmers. Rather, their purpose is to encourage farmers and farming communities to nurture, conserve, utilise and improve plant genetic resources (Food and Agriculture Organisation 1993). In the development of a new sui generis system for Papua New Guinea, focus should be placed on the rights of farmers and local communities.

\section{Conclusion}

The purpose of the discussions in this volume is to provide an informative basis for the citizens of Papua New Guinea to discuss how to respond to issues about use of, and access to, genetic resources. The Convention on Biological Diversity has effectively challenged nations to think creatively about national sovereignty, conservation and the sustainable use of plant genetic resources; about fair and equitable sharing of the benefits arising from the use of these resources; and about 
how Papua New Guinea might best protect its rich diversity in plant, animal and marine genetic resources.

Hopefully the suggestions and ideas set out here will continue to stimulate discussion at higher government levels. Most importantly, this discussion should lead to action, in particular to develop relevant and appropriate legislation on intellectual property rights to protect the interests, knowledge and techniques of the farmers and local communities who have helped to give us access to the wealth of biodiversity we enjoy today. 


\section{9 \\ Genetic, biochemical and medicinal resources \\ how much can we own, protect and receive credit for?}

\section{Lohi Matainaho}

Papua New Guinea has for many years been a site and focus of many social and scientific research activities carried out by academic and research institutions both from within its borders and from overseas. The country has been a target for these activities because of its diverse assembly of language, people and environment. It is generally acknowledged that the population of Papua New Guinea is the most culturally diverse in the world and that it has a highly diverse biological environment. Such diversity and the interaction of people with the natural environment in an island country for many thousands of years has provided a rich resource base for genetic, biochemical and medicinal research discoveries.

In the last 10-15 years there has been an unprecedented interest in bioprospecting in Papua New Guinea, as there has been in other developing countries. Prospectors look for human, animal, plant and soil-derived genetic and biochemical material that may be of commercial value. The scrutiny of biological diversity, guided by traditional knowledge regarding diseases and treatments, has led to useful ethnobotanical information that may be important in discovering bioactive compounds for pharmaceutical and agricultural purposes.

Screening tests on plant material derived from traditional knowledge tend to yield a higher percentage of positive results compared with screening on the basis of random collections (Cox and Balick 1994). Traditional medicinal knowledge has therefore made easier the 
identification of useful compounds. Papua New Guinea has now become a target of drug research by many institutions from developed countries.

\section{Genetic and biochemical resources}

Many research studies in Papua New Guinea have revealed biological characteristics unique to its people, and have therefore provided useful information about their behaviour and survival, as well as the biochemical characteristics and profiles of diseases. Studies have also shown the occurrence of certain diseases or strains of viruses and parasites amongst population groups which illustrate geographical pooling or clustering. This provides evidence of inherent mutations and of the process of coevolution (Katz and Skalka 1990; Doolittle et al. 1989).

Pioneering research carried out by Carlton Gajdusek and coworkers from the 1950s to the 1970s on the Fore people of the Eastern Highlands led to the discovery of a variant form of Creutzfeldt-Jacob Disease, commonly known as kuru (Zigas and Gajdusek 1957; Alpers and Gajdusek 1965). Gajdusek later received a Nobel Prize for this work. More recently a discovery was made of a variant human T-cell lymphoma/leukemia virus type I (HTLV-I) among the Hagahai people (Yanagihara et al. 1990; Yanagihara et al. 1991). This finding resulted in the patenting by United States scientists of a human cell line derived from the blood of a Hagahai man. Discoveries like these, made from human blood, support and complement the functions of the Human Genomic Diversity Project. The project is aimed at collecting blood, especially from isolated and less known populations, in an attempt to discover gene sequences that may be useful in gene therapy. Geographical and ethnic confinement of critical data have therefore been a strong base for scientific reasoning and explanation for disease patterns, transmission and variation (or evolution). In the area of malaria research there are current efforts to trial antigens, some presumably derived from Papua New Guinea sources, as possible vaccine candidates for the disease.

There is no doubt that medical discoveries originating from Papua New Guinea have led to the elucidation of the molecular mechanisms of disease and consequently the development of appropriate strategies for the control and treatment of specific and related diseases. Unfortunately, many such discoveries and their potential applications - which have been conveyed in scientific journals and international meetings-have been credited almost entirely to the scientists involved and their grant donors, without any credit to the source of the original material. 


\section{Traditional knowledge as a medical resource}

Traditional knowledge regarding diseases and their treatment has been part of the evolving cultures of many communities in Papua New Guinea. This knowledge is passed from generation to generation. Societies in Papua New Guinea are rich in knowledge about the use of plant and animal material for treating illnesses (Holdsworth 1977).

Surveys of medical practices and traditional uses of plants over the last 100 years have documented some of this knowledge (Hill 1985). However, traditional understanding regarding the aetiology of diseases, their diagnosis and treatment is generally viewed by Western medicine as having no scientific basis. Scientific-based principles regarding proper diagnosis of diseases and knowledge about the efficacy and toxicity of plant drugs is lacking. Despite that, there has been much anecdotal support for traditional therapies using plant preparations. Indeed, many clinically useful drugs such as vincristine (anti-tumor), morphine (analgesic), codeine (antitussive/analgesis), quinine and artemisinin (anti-malaria) are derived from medicinal plants. But, even with such a contribution, medicinal plant preparations must still be subjected to rigorous scientific testing to ascertain their safety and make known the active components (Wesche 1987).

\section{Natural products and drug discovery: an example}

Interest in natural product screening and development has been expressed and planned by local individuals and institutions such as the University of Papua New Guinea and the Papua New Guinea University of Technology in collaboration with other organisations. Previous and current practice has been to accept or invite international scientists, who invariably have connections with major drug companies, to come and take plant and marine samples for intensive drug screening. Questions pertaining to credit or compensation to the resource owners and owners of the knowledge have rarely been addressed. In the event that a major drug discovery is made, whether directly or indirectly, from the crude material from Papua New Guinea, it is possible that Papua New Guinea would never know about it. This may mean that any significance of that discovery to traditional knowledge is also lost.

A project to develop drug discovery programs using Papua New Guinea plants is being prepared jointly by researchers from the University of Papua New Guinea, the University of Utah and the United States National Cancer Institute. The arrangement includes three months of training for the author 
at the United States National Cancer Institute. The training will involve techniques using various cancer cell lines, including a non-infectious strain of human immunodeficiency virus (HIV).

Another investigator, Dr Todd Capson of the University of Utah, has been conducting ethnobotanical surveys on the uses of plants by the people in the Lakekamu Basin in the Gulf Province and the Crater Mountain area of the Eastern Highland Province. Recording of knowledge is based on people's willingness to share and to safeguard valuable information before the people who have that information die. Dr Capson's work in these areas is being carried out in collaboration with the Foundation of the Peoples of the South Pacific/Papua New Guinea, Inc. and the Research and Conservation Foundation of Papua New Guinea respectively (Capson forthcoming). It is hoped that the University of Technology, the Papua New Guinea Institute of Medical Research and other institutions may become involved.

The project is also intimately concerned with the protection and conservation of the natural flora and fauna and the promotion of sustainable use with a low or no destructive impact-but with maximum benefits for the community. For example, the discovery of a drug would mean improvement of health and lifestyle and the protection, preservation or cultivation of the plant, not to mention the economic benefits. Research efforts will no doubt be coordinated with Papua New Guinea-based conservation organisations.

\section{Agreement for drug discovery}

Before any work on the drug discovery project begins, a detailed agreement between the resource owners and the participating institutions in Papua New Guinea and the United States will have to be developed and signed. It is proposed to involve Conservation International, a major international non-government organisation, in the preparation of the agreement.

The basis of the agreement is to give equitable recognition or compensation to the people for the knowledge and resources they own (as original owners), and to realise their role in the development of a natural product. Contractual arrangements will include

- authorisation for access and collection of materials

- transfer agreements between institutions

- sharing of royalties and rights to ownership of discoveries.

Long-term benefits for the country include the development of scientific infrastructure and human resources. Research and development will be an 
integral part of the project. The agreement will no doubt maintain some degree of flexibility to enable those involved to explore carefully the extent of traditional ownership and transparency in the project.

\section{How much can we own, protect and receive credit for?}

Issues of ownership and access to genetic material in developing countries have generated much discussion in recent years and played an important part in the discussions that led to the signing of the Convention on Biological Diversity in Rio de Janeiro in 1992. The Convention recognises the ownership of biodiversity by sovereign countries and calls for equitable economic sharing arrangements between resource owners and users. However, it fails to make clear a provision for human genetic resources.

Underpinning the issue of ownership is the inherent value of the material, commodity or knowledge to the people concerned. In traditional Papua New Guinea societies, a value cannot be determined absolutely. Instead, values are relative and equal to exercising one's right and privileges to something before someone else. Relationships in this context are fundamental components. The value of the object per se is not necessarily the critical issue of contention. Equally important could be simply respecting the perspective that 'it is not an issue of money; it's one of respect for our ideas in creating knowledge that will help people'-as was recently argued by a leading scientist who was left out in a patent (Nowak 1995:899).

Ironically, it may take an outsider to recognise the relevance and value of plant or human genetic material and knowledge (for example, ethnobotanical information) to the wider community. Value in this case may assume a different contextual meaning. In general, value or relevance to other people is perceived easily, but value for commercial purposes inserts a new dimension into what may not have been the original purpose-although the use-purpose is generally acknowledged. This new purpose or perspective brings in the concept of added value. If this can be equated to value added to a commodity, then a tax-royalty compensation can be considered, similar to the concept of value added tax. This taxroyalty compensation would be relative and depend on the added value of the new or modified product.

Ownership and value in traditional communities mean status and respect, as, for example, in being a leader. Such a position in the community can be compromised if valuable knowledge is disseminated or 
lost to other people. Protection of possessions, whether they are materials or knowledge regarding an art or skill, must therefore be guarded jealously. But, as with other systems, circumstances can change. Given the variability that exists amongst villages, the rules regarding ownership can be stretched. Such dynamism in the traditional realm also assumes that the principles governing ownership in communities or villages in Papua New Guinea are similar but with boundaries that vary greatly. For example, flexibility in allowing cultural material or information to be shared may differ amongst groups.

These observations provide some guiding principles (though are not exhaustive, by any means). On the basis of these, it is possible to observe that the answer to the question of how much can we own, protect and receive credit for must reflect the following important considerations

- ownership of the original material and knowledge

- value attached to helping other people

- commercial value

- value added by modification and development.

'Original material and knowledge' acknowledges the fact that there is a source or proprietor, and value attached to an idea or thing. This implies ownership and an already existing relationship between the owner and the material or the knowledge. Such a relationship may be typically equated to an inherent value, which at the village level (that is, the level of original use) is absolute or 100 per cent of the value of the material of knowledge.

'Helping other people' acknowledges that people other than the original owner are sharing and benefiting from the traditionally derived material and knowledge. The new users may include those in the same village, outside communities or even scientists. This level is generally noncommercial, and as such is normally based on trust and confidentiality. The inherent value is intact only as far as the original use and purpose is exercised or implied in full. Full credit is therefore due to the resource owners. But in the event of a new use or potential being uncovered, this will lead to a new value being introduced, and will therefore reduce the inherent value (that which is related to the original use or purpose). In principle the inherent value becomes relative to the exercise of the new use. In this respect, some acknowledgment or credit to the resource owner would generally be appropriate.

'Commercial value' acknowledges that there are other values and interests attached to an idea or thing. The original use or the new use may become commercially valuable. An appropriate determination can therefore be 
made based on the principles stated above. In this situation, acknowledgment or credit should follow the manner of the interest being expressed along commercial lines. The inherent value, if it can be determined, may assume the character of a tax-royalty compensation where it is dependent on the new value being added.

'Modification and development' acknowledges the input of others to derive something new-with a new value attached. This level is generally the same as commercial value but recognises the novelty of the material or product being developed from what was derived from the resource owners. The original source of the material is generally not recognisable or visible.

Novelty can shift much of the credit or benefits to the discoverer with little or nothing going to the resource owners. For this reason, the issue of inherent value can be difficult to determine other than in the context of being the source of the new product. In addition, the novel product may also assume its own inherent value which may decrease the value that should go to the resource owners.

Despite this difficulty, the value accorded to the resource owners can be made more tangible by involving the resource owners as partners in the development of novel products using their resources. Although their involvement may not be visible in the laboratory, there can be clear transparency as to their involvement up to the final stage of product development. In this way, resource owners can continue to exercise some ownership over the products that are being developed from their traditional base.

A careful analysis and consideration of these issues can ensure that people receive a fair share of what was originally derived from them. One should keep the big picture in mind. Under the model proposed here, resource owners would be partners with scientists (and other interest groups) in developing plant-derived medicines for commercial and health use to benefit them and all humankind. The greater involvement of people in such enterprises can only maximise what they can own, protect and receive credit for. 


\title{
10 \\ Access to genetic resources legal and policy issues
}

\author{
Kathy Whimp ${ }^{1}$
}

Much of the world's biodiversity is located in developing countries. Many of the food crops we rely on today were originally sourced from countries which are now developing or emerging industrial economies. Germplasm of many kinds has been exchanged for many years for a variety of reasons, mostly associated with agriculture.

During the last 20 years, there have been dramatic changes in the significance of genetic material in economic and social terms. New technologies mean that some kinds of genetic material are now valuable resources for the development of yet other technologies, processes and products. As commercial interest in genetic material has grown, there has been increased pressure for intellectual property right protection to be available to protect those commercial investments. At the same time, developing countries have expressed concern about their genetic heritage being exploited with little or no recompense.

These changes have generated a dynamic and complex environment. There are many developments at national and international levels. Most are at the cutting edge of law and government administration. Many countries are uncertain about how to proceed, while at the same time feeling impelled to act quickly. This chapter examines the background to the emergence of this important international policy debate. It canvasses the possible approaches to securing better protection for national biodiversity resources, including intellectual property rights and access regimes. The chapter concludes that while intellectual property rights on 
their own have limited value there are many problems in using existing intellectual property law, particularly where resources are owned by indigenous landowners rather than the state. Countries like Papua New Guinea are likely to gain greater flexibility and broader protection from legal regimes that regulate access to genetic resources and prescribe the terms on which they can be used, including the diposition of any intellectual property rights.

\section{Background: ownership of genetic resources}

In a Western cultural context, products of nature were for a long time regarded as the common heritage of humankind (Margulies 1992). In a legal sense, the ownership of genetic information in plants and animals has generally not been distinguished from ownership of the physical biota themselves.

Over the last 50 years, concern has mounted that this heritage might be lost as the pool of genetic stock from which commercial agricultural crops come has shrunk. In response to concerns about the future food security of the world, a variety of plant genetic material was collected into a number of genebanks around the world. Although independent, they are managed through an international network linked by the Consultative Group on International Agricultural Research. The majority of this material is held outside the countries where it was originally collected, and the origins of much of it can no longer be determined.

\section{International Undertaking on Plant Genetic Resources}

In the 1970 s, developing countries began to express concern that they might lose access to the genetic material held outside their territorial control. In 1983, the UN Food and Agriculture Organisation oversaw the development of an International Undertaking on Plant Genetic Resources, which forms the basis for a global system of access to genetic resources for food and agriculture. Between 1989 and 1994, the Food and Agriculture Organisation negotiated with the Consultative Group on International Agricultural Research to place its genebank collections under the control of the Food and Agriculture Organisation network, and to agree that they should not seek intellectual property rights in relation to any of the material held there. 
In 1991 the Undertaking was renegotiated to provide for recognition of individual states' national sovereignty in the biological resources originating within their territory (Margulies 1992). However, the Undertaking was, and is, a non-binding document. It was renegotiated again during April 1999, and a major issue for consideration was its adoption as a legally binding international instrument.

\section{Convention on Biological Diversity}

The Convention on Biological Diversity entered into force in December 1993. It is the first international instrument to recognise the national sovereignty of individual states over genetic resources. It specifically addresses the issue of access, and requires that countries take steps to facilitate access by other countries to their genetic resources (Article 15). It also requires that

- access be subject to prior informed consent by the providing country (Article 15.5) ${ }^{2}$

- the terms of access should be mutually agreed (Article 15.4)

- states should protect indigenous and local knowledge and ensure that these communities share equitably in the benefits of utilising their knowledge (Article 8(j))

- states should make technology for the conservation of biodiversity available to other countries on mutually agreed terms, subject to intellectual property rights (Article 16).

\section{The significance of intellectual property}

Concerns about the disposition of genetic material do not relate to the physical substance of the biological material. Rather, the concern is that others may use the genetic information, or the molecular structure of chemicals within the material, and benefit from the use of that information. Intellectual property rights are the principal way in which rights to control the use of incorporeal property (that is, property that does not have a physical form) are recognised.

Information or ideas can be protected in several different ways within the framework of most Western (Euro-American)-based legal systems (see Harroun, this volume). The type of intellectual property right most relevant to a discussion of genetic material is patents, which protects inventions and processes. A patent allows the owner to prevent any other person making the same invention, or using the same process, without his or her permission. 


\section{Patents}

Commercially valuable ideas only remain valuable while they give the owner of the idea an advantage over her or his competitors. The owner of an idea can maintain this advantage in two ways-either the idea must be kept a trade secret (like the formula for Coca-Cola) or there must be a way to prevent a public idea being used by everyone. Patents provide a legal means of restricting ideas that the inventor has placed in the public domain.

Patents reward individuals for investing their creative effort in developing an idea. In return for protection, the individual must make the idea public through a registration system. This means that other inventors have access to the idea and can use it to develop further technology. A central policy goal of patent systems is to encourage and facilitate scientific and technological discovery.

The protection offered by patents can be described as a 'temporary exclusive economic monopoly right' (Lesser n.d.). The owner of such a monopoly right can stop all others from using his or her invention. In this way, the commercial value of the invention is maximised because its use is limited. However, this special monopoly continues for only a limited period. In most countries, patents last for around 20 years, after which the invention is freely available to be manufactured or used by anyone.

A major reason for the effectiveness of patent protection is the reciprocal recognition that is available in other countries. Under the Paris Convention of 1883 , member countries undertake to protect the citizens of other countries in the same way as they treat their own. This protection was expanded in 1970 by the adoption of the Patent Cooperation Treaty, which establishes a system for making one single application for a patent that has effect in all member countries.

The operation of the international patent system is further enhanced by the adoption of common approaches by the majority of industrial countries. Under the Strasbourg Agreement of 1971, a uniform system of classification has been adopted. Difficulties in describing microorganisms for the purpose of a patent application are covered by a system of 'approved depository authorities' established under the Budapest Convention of 1977 (Whimp 1997b). 


\section{Intellectual property rights and genetic resources}

Traditionally, products of nature could not be the subject of patent protection. This rule was established in a 1908 United States case in which a patent application for an object made from cork was refused (Bozecevic 1987). In order to be granted a patent, an invention must satisfy the criteria of novelty, non-obviousness and usefulness. Nonobviousness means that the invention must demonstrate that some skill or art was involved in the invention. Products of nature usually fail to satisfy both the novelty and non-obviousness criteria.

\section{Plant variety rights}

In the 1930s, the United States government enacted a law offering protection for plant varieties, in order to promote the development of a plant breeding industry. Plant breeder rights, or plant variety rights, are a system of sui generis (one of a kind) protection for varieties of plants that have been artificially propagated. Protection offered by this type of intellectual property right is similar to patent protection-the breeder is granted a legal right to control other's reproduction of the plant, in return for disclosing the method by which the new variety was derived.

By 1961, there was sufficient interest to establish an international convention dealing with plant variety rights. The International Convention for the Protection of New Varieties of Plants was adopted in 1961 and significantly revised in 1978. Almost all the members are developed countries. Several other countries have plant breeder rights legislation, but do not belong to the International Convention for the Protection of New Varieties of Plants.

The restrictions applied to plant variety rights under the International Convention for the Protection of New Varieties of Plants have meant that it was not of much use to developing countries. In practice it has a fairly limited application to ornamental and some agricultural plants. In 1991, the Convention was updated to make it even more restrictive from a developing country point of view. The provisions of the Convention also now prevent farmers from using saved seed from protected varieties. The requirement to demonstrate that a variety is 'distinct, uniform and stable' means that few indigenous farmers would be able to satisfy the criteria for protection (Crucible Group 1994). 


\section{Biotechnology}

Perhaps the most important change affecting intellectual property rights as they relate to plants was the emergence of new biotechnology techniques during the 1970 s (Lesser n.d.). In particular, the availability of recombinant DNA and hybridoma techniques made it possible to artificially develop organic materials and substances that were quite distinct from their biological components, and therefore able to be patented (Power 1992).

At least in the United States, intellectual property law kept pace with technological developments. In 1980, the US Supreme Court in the decision of Diamond $v$ Chakrabarty ${ }^{3}$ upheld a decision of the Patent Office to award a patent to an artificially modified microorganism. Applications for patent protection in the United States now embrace a wide range of biologically derived materials and processes, including pharmaceuticals, antibodies, vaccines, enzymes, cell lines, first generation plant hybrids, processes for synthesising these materials, diagnostic processes and kits, and treatment processes (Power 1992).

Elsewhere in the world, patent laws are often much more restrictive. A number of countries, principally developing and newly industrialised, do not permit the patenting of a wide range of biologically derived products including pharmaceuticals. These restrictions usually have a moral basis, and emerge from ideas that life forms should not be the subject of private property rights, or that pharmaceuticals should be freely available (Gollin 1993:169; Simpson 1997:72-3).

\section{Intellectual property in the international context}

\section{Convention on Biological Diversity}

During the debate that preceded the adoption of the Convention on Biological Diversity, a major dispute erupted within the international community about provisions relating to the transfer of technology from industrial to developing countries. While developing countries wanted industrial nations to make technology for the conservation of biodiversity available to them on a preferential basis, the representatives of industrial countries objected that their citizens should be entitled to have their intellectual property in that technology protected. They argued that the owners of technology should be entitled to refuse access in countries where such protection would not be available (Margulies 1992:335). 
The compromise provisions appearing in Article 16 of the Convention on Biological Diversity make for confusing reading (Goldman 1994:708). However, it appears clear that developed countries are entitled to refuse access to technology if the recipient country is not able to offer protection for intellectual property.

\section{World Trade Organisation and the Trade-Related Aspects of International Property Rights Agreement}

The significance of intellectual property in the international context increased further with the Uruguay Round of the General Agreement on Tariffs and Trade, concluded in 1993. The negotiations resulted in the establishment of the World Trade Organisation and the signing of a major agreement dealing with intellectual property.

Three countries in the Pacific island region (Papua New Guinea, Fiji and Solomon Islands) are members of the World Trade Organisation and are bound by the provisions of the Trade-Related Aspects of International Property Rights Agreement. Under the Agreement, members of the World Trade Organisation must adopt intellectual property rights legislation covering

- patents (in the form specified by the Paris Convention)

- copyright (in the form specified by the Berne Convention)

- protection of plant varieties (either under patent or under a sui generis system like the International Convention for the Protection of New Varieties of Plants)

- trademarks, geographic indications and designs, including integrated circuit layout designs

- trade secrets (as required by the Paris Convention) (Whimp 1997b). Developing countries (including Papua New Guinea) that are making a transition to a market-based economy have until 2001 to comply. Least developed countries have until 2006 to comply with the terms of the Trade-Related Aspects of International Property Rights Agreement (Article 65). Even countries with no intellectual property rights laws are required to accept patent applications for pharmaceutical and agricultural chemical products from the beginning of the transition period, so as to preserve the novelty of the invention for the time when patent laws are in place.

The inadequacies of the Trade-Related Aspects of International Property Rights model of intellectual property rights for protecting 
interests in unmodified genetic resources and the traditional knowledge of indigenous people has been the subject of much debate internationally (Simpson 1997:114-29).

\section{Access to and use of genetic resources}

A number of developing countries with globally significant biodiversity (and at least one developed country, Australia) are currently experiencing an increased interest in access to these resources for commercial purposes. This interest may provide an opportunity for sustainable use activities, transfer of technology and the potential for some financial gain. However, it also presents real challenges to ensure that these benefits are maximised, and that possible negative consequences are avoided.

Exchange of genetic material has occurred on an informal basis between Pacific island nations for some time. Exchanges have involved genetic material of local food, agriculture and tree crops. Because most of this exchange has occurred either at a customary level, or between government agencies, it has not raised questions about the inappropriate exploitation of the material for commercial purposes. However, recent experience of unauthorised use of genetic material (including, in one case, human genetic material) has caused offence and concern in many quarters. ${ }^{4}$ In addition, there are now fears that the traditional ethnobotanical knowledge of indigenous people may also be exploited.

The issue of greatest concern in controlling access to genetic resources relates to bioprospecting for chemical compounds found in plants that might yield useful material for the production of pharmaceuticals. The way in which bioprospecting is carried out makes it difficult to control. A relatively small amount of vegetative matter is required to produce a sample for screening. ${ }^{5}$ In some cases, screening (for anti-cancer compounds, for example) can be carried out within the country. Illicit export would be very difficult to detect. The difficulty in policing illegal bioprospecting means that attempting to prohibit it is unlikely to be successful. In any case, there may be significant benefits to be gained through properly negotiated and monitored arrangements. These advantages are already being recognised by a number of local research institutions that are entering into agreements with developed country counterparts, usually acting on behalf of large pharmaceutical firms.

Research institutions, however well meaning, may not necessarily be in the best position to consider and balance all the national and local 
considerations that should form part of a response to commercial bioprospecting proposals. However, in the absence of national policy or legislation, they at least provide an institution with whom prospective prospectors can negotiate.

A particularly important consideration in the case of commercial proposals for accessing genetic resources is the control of intellectual property rights in something that might be discovered. However, the chances of making a successful find are not high-around one in 10,000 leads produces a drug that proceeds to clinical trials (Reid et al. 1993b:7) (although one plant species can yield hundreds of leads). When a find is successful, the financial returns may not be as high as some expect. Royalties for unproven samples (those that have not been subject to preliminary testing) reportedly range from 1 to 5 per cent of net sales (Laird 1993:11). Net sales in this case would mean profits after research and development costs and production and distribution costs are deducted. In the case of pharmaceuticals, research and development costs are extremely high. In the early 1990s it was estimated that the average cost of producing a marketable drug was US $\$ 231$ million, most of which was spent on clinical trials (Reid et al. 1993b:16).

These factors should lead developing countries to be cautious about how much they spend establishing and maintaining regulatory systems to capture what may be a marginal financial benefit, when compared to the cost of administering the system. On the other hand, there are also important social opportunities for the protection of indigenous knowledge, creation of incentives for conservation and the promotion of opportunities for sustainable rural development activities. All these considerations must be balanced in developing a locally appropriate approach.

Regional implications of initiatives to assert sovereignty over genetic resources are also an issue. Problems of this kind are illustrated by the rosy periwinkle biospiracy described by Goldman (1994:718). International pharmaceutical company Lily manufactured an anti-cancer agent from the rosy periwinkle. Accounts usually attribute the plant to Madagascar, where it was first harvested. In fact, it is cultivated or grows wild in most semi-tropical and temperate parts of the world. Investigation of the periwinkle began because of folklore in the Philippines and Jamaica about its use as a tea in cases of diabetes. The plant was subsequently harvested in India and Madagascar for initial production of the drug, and eventually put under commercial 
cultivation in Texas. In such circumstances it is not at all clear who should benefit from is exploitation. This is not to suggest that the developing countries involved were not entitled to compensation, but rather to illustrate the difficulties in equitably distributing it.

The distribution of species across the Pacific and in Asia means that national systems have the potential to disenfranchise neighbouring countries, even though that was not intended. There is a potential for disputes between countries to arise unless bioregional arrangements are in place to resolve them.

\section{Possible approaches}

$A$ vigorous and fertile international discussion of these issues and how to address them has emerged over the last decade, and has gathered pace in the last five years. There are two distinct aspects to bioprospecting that involve separate legal issues. First, traditional knowledge about wild plants and their medicinal uses should be protected from exploitation. Second, the use of genetic resources themselves should be controlled through a system that ensures an appropriate level of consent, and an equitable distribution of benefits from their use.

The need for protection of traditional knowledge has generated a number of suggested approaches that focus on recognition of the importance and value of this knowledge

- protection of farmers' rights, partly as a counterbalance to plant breeder rights

- application of trade secrets to traditional knowledge

- development of sui generis (one of a kind) intellectual property rights systems to protect indigenous rights

- codes of ethics for researchers dealing with communities. Not many of these approaches have been carried into effect, and so there is little available precedent to guide countries in adopting them.

The protection of genetic resources has been approached from a number of different angles, and the following solutions are in use or have been suggested.

- Codes of conduct for collectors.

- Development of intellectual property rights for plants (either plant breeder rights or patents).

- Access regimes, including research or materials transfer agreements, sometimes secured by collectors' licences or permits. 


\section{Merck-Inbio: bioprospecting partnership agreements}

The Merck-Inbio arrangement is an example of an approach adopted by one country which aims to protect indigenous knowledge, to ensure a financial return, provide access to technology and training, as well as leveraging conservation benefits. Under this arrangement, the Inbio institute, on behalf of the government of Costa Rica, entered into a detailed and comprehensive partnership agreement with the pharmaceutical company Merck, to prospect Costa Rica's rich tropical forests (Reid et al. 1993a).

The agreement involves a substantial upfront payment, support for the establishment of local institutions, transfer of technology and equipment and a share of royalties. It should be noted that some commentators have criticised the agreement on the basis that the upfront payment of US $\$ 1.13$ million is a small price to pay for access to such a large reservoir of biodiversity (Simpson 1997). However, it is difficult to know the real value to Costa Rica without knowing the terms that have been agreed about royalty sharing, and these are confidential (Laird 1993:111).

Papua New Guinea would do well to study the Merck-Inbio arrangement, and might consider a partnership with one company preferable to managing a number of small contracts. However, it is also important to remember that what makes Costa Rica attractive to a potential bioprospector is its stable and well developed administrative infrastructure, a long history of political commitment and funding for environment projects and the availability of highly skilled professional staff to undertake the taxonomy involved.

The approach adopted in Costa Rica involves a level of state control over biodiversity that might not be acceptable to people in Papua New Guinea. The Costa Rican government has recently enacted a Biodiversity Law (Ley de Biodiversidad) that declares that while animals and plants can be privately owned, their genetic and biochemical properties are the property of the state (Rivera and Cordero 1999).

\section{Protecting traditional knowledge and genetic resources with intellectual property rights}

Genetic resources in a natural, unmodified state cannot be the subject of patent protection. Traditional knowledge also does not lend itself to 
protection under existing patent law systems. Patents create individual rights. In a number of countries, the person applying for the patent must establish that they are the inventor of the process being described. Knowledge about a particular use of a plant that has been handed down through generations may be a sufficient basis for patent protection (Huft 1995), but a patent application may cost around US $\$ 20,000$. Even if these expensive rights are obtained, they expire after 20 years, leaving the information legally in the public domain.

Trade secret law is probably a more appropriate form of protection for traditional knowledge, because it does not expire unless the secrecy is waived (by publication, for example), and requires no formal process of proof or registration. However, to maintain protection, the group needs to keep the information secret. Information that is secret can be divulged (for example to a bioprospector) provided there is a contract requiring the third party to maintain confidentiality. Any unauthorised use could be the subject of a legal action and might invalidate a patent based on it.

Ironically, some indigenous communities may be encouraged to give away the possibility of trade secret protection in order to protect their knowledge being copied by third parties. Although traditional indigenous knowledge is rarely of itself the subject of patent applications, many indigenous communities have experienced researchers publishing accounts of their knowledge and obtaining copyright over those publications. The best protection against copyright misappropriation is prior publication by the group itself. However, the voluntary publication of material may also rule out the possibility of trade secret protection.

\section{Codes of ethics for researchers}

Some of the infringements of indigenous rights can be addressed through more ethical behaviour by researchers. Guidelines of this kind are included in the Code of Ethics of the Australian Anthropological Society. Such a code might include a requirement for knowledge not to be published without the specific permission of those from whom it was obtained, and/or requirements for joint copyright to be specified on publication. The Manila Declaration, adopted at the seventh Asian Symposium on Medicinal Plants, Spices and Other Natural Products, contains some ethical guidelines for scientists engaged in ethnobotanical collecting. Several others are available. ${ }^{6}$ 


\section{Community intellectual property rights}

A number of commentators have proposed that a special sui generis form of intellectual property rights should be created to protect the traditional knowledge of indigenous people (Simpson 1997:146). It has also been suggested that this alternative system might provide a way for developing countries to meet their obligations under the Trade-Related Aspects of International Property Rights Agreement (to provide protection for plant varieties), while respecting the traditional knowledge systems that are fundamental to their culture. In 1994, a project by the Third World Network produced a draft Community Intellectual Rights Act setting out a very broad framework for recognition of community custodianship of innovation and commercial use of indigenous knowledge. In 1998, the Organisation for African Unity produced a Declaration and Model Law on Community Rights and Access to Biological Resources. Both drafts are expressed in extremely broad terms and, for example, contain no mechanisms for enforcement.?

Sui generis systems have two major disadvantages that should be considered carefully. First, a system of intellectual property rights is only as good as the capacity to enforce it, generally within the country where the law was passed. It is highly likely that infringements of indigenous intellectual property rights-for example, by the patenting of a chemical compound based on traditional knowledge about its use-will occur outside the country where the indigenous owners live. In other words, unless other countries-in particular developed countries whose citizens are most likely to infringe traditional rights-adopt reciprocal or complementary systems, the protection offered by sui generis systems will be limited to the country in which the law is enacted.

Second, proposals for sui generis systems raise problems about the legal identification of the group that owns traditional knowledge, and how that information is handled in transmission through generations and between groups as a result of customary practices. Still more problems arise if more than one group possesses the same knowledge.

A project is underway in Ecuador to establish a 'cartel' over indigenous knowledge. It involves a system of regional depository databases, that are kept confidential unless it appears that knowledge is registered by more than one group, in which case they may jointly negotiate the release of the information (Simpson 1997:80). It appears 
that a large and relatively expensive infrastructure is involved in such a system.

The Ecuador proposal works on the basis of trade secret protection, rather than establishing a new system of rights. On balance, trade secret protection does seem to be the most useful way to protect indigenous knowledge, provided the knowledge is not yet in the public domain and its continued secrecy can be maintained by contracts with third parties. A law that asserts the rights of indigenous people to be protected by trade secrecy, and provides an easy means for them to assert that protection, could provide a useful complement to access and contract systems described below.

\section{Access regimes}

By far the most widely adopted approach to protecting the interests of developing countries in genetic resources is through the development of access regimes. An access regime is a framework for setting the terms on which people may access genetic resources within the country. It is an exercise of national sovereignty as envisaged by the Convention on Biological Diversity. To be effective, the framework of a legal regime controlling access to genetic resources should have three elements

- a set of rules (whether imposed by law or as a matter of policy)

- a clear division of responsibility for decision making about access proposals

- the capacity to implement the rules and make decisions.

A number of countries have adopted, or are considering, access regimes. Most, but not all, are imposed through legislation. They include

- Philippines Executive Order 247

- Fiji draft Sustainable Development Bill, clause 254

- Andean Pact (Cartagena Agreement Commission) Decision 391

- Western Australia Conservation and Land Management Act

- Costa Rica Ley de Biodiversidad

- International Collaborative Biodiversity Group Peru (see Tobin, this volume)

- University of South Pacific and Verata Agreement

- Samoa draft access regulations

- Organisation for African Unity Model Law on Community Rights and Access to Biological Diversity

- Thailand draft Act on Protection of Thai Medical Wisdom

- proposed amendments to Nigeria National Parks Act 
- 1993 Food and Agriculture Organisation drafting instructions for legislation for Seychelles

- Second Draft Eritrean Proclamation on Conservation of Biological Diversity 1996

- Mexico Environment Act 1996

- Peru Law for the Conservation and Sustainable Use of Biodiversity 1997

- The Gambia National Environmental Management Act 1995

- Kenya Draft Environmental Management and Coordination Bill 1995

- Malawi Environmental Management Bill 1996

- Republic of Korea National Environmental Preservation Act 1991, as amended in 1994

- Uganda National Environmental Statute 1995 (Glowka 1998). The basis of almost all access regimes is a contract permitting access on specified terms and conditions. These agreements are sometimes called research agreements, and sometimes materials transfer agreements (both might be used for different purposes). They can be secured by a law that prohibits access without a permit or licence, or they may be imposed simply as a result of government policy. Where foreigners are concerned, it is usually possible to impose requirements simply through immigration restrictions as a condition of visas, for example. If there is concern that citizens within a country are involved in bioprospecting, then a separate law will be needed to enforce the requirement for contracts prior to accessing genetic resources.

\section{Codes of conduct for collection}

Codes of conduct are a useful way of setting a common framework for an activity, particularly where the persons or bodies to be bound by it are already in a relationship with one another, and there is a general desire to do the right thing. The exchange of germplasm between Pacific island country governments has been occurring for some time. Agencies involved in tree and food crop improvement programs regularly undertake such exchanges, with mutually beneficial aims. In recognition of the growing sensitivity about these exchanges, a number of programs have developed codes of conduct that regulate the process of collection. Most of them provide that intellectual property in the genetic material remains with the donor country, and there are restrictions on the transfer of material to third parties. 
Other codes of conduct for collection are also available and might be adopted for use. These include the Food and Agriculture Organisation Draft International Code of Conduct for Plant Germplasm Collecting and Transfer, and the provisions of the Manila Declaration on the Ethical Utilisation of Asian Biological Resources, adopted at the seventh meeting of the Asian Symposium on Medicinal Plants and Spices. It includes suggested minimum standards for contracts between collecting organisations and their developing country hosts. A number of codes of conduct are available on the Working Group on Traditional Resource Rights website. ${ }^{8}$ Many provide similar comprehensive lists of possible conditions for an access regime.

\section{Elements of an access regime}

\section{Scope}

An access law or policy should specify the scope of coverage of the activities that are permitted and that should be undertaken in accordance with the scheme. The scope of an access regime will be governed mainly by the way key concepts are defined. Genetic resources and biodiversity might be defined widely (to include knowledge about genetic resources, for example) if there are concerns that prospecting activities may take place without samples actually being removed. Reference to the definitions in the Convention on Biological Diversity would be useful. Bioprospecting should also be carefully defined, since many activities involve the taking of small amounts of vegetative material (harvesting tea, for example) that should not be accidentally captured by the scheme.

There should be provision to limit the scope of application to particular species or habitats, depending on rarity, ecosystem fragility, danger of genetic erosion or risk of adverse social impacts. The harvesting of human genetic material should be excluded from the scheme. In addition, most access regimes exclude customary transfers of material from permit requirements. In some cases it may be appropriate to extend this to customary transfers between countries.

\section{Competent national authority}

An essential element of an access regime is a national body with whom research agreements or materials transfer agreements should be negotiated. Multiagency groups (involving representatives from a 
number of interested departments) are a common choice, but these sometimes have the disadvantage of being slow to make decisions, and they can be too cumbersome in some situations to negotiate adequately. Legislation may be needed to give a body of this kind the legal status to enter into binding contracts with bioprospectors, or the body may act in an advisory capacity to another authority, such as a minister, who ultimately signs contracts.

In some cases it may be more appropriate to use existing sectoral bodies operating within a clear framework and with an independent agency (such as the Attorney-General's office) involved in overseeing compliance. If existing agencies are used, it may be more appropriate to amend their existing legislation than to develop a new Act (if legislation is desired). However, the dangers of duplicating licensing requirements should be borne in mind.

In the absence of national policy or legislation, research organisations in Pacific island countries are taking on the role of negotiating the terms on which access occurs. While these organisations have considerable knowledge about these issues, they cannot assume the role of granting consent to access genetic resources on behalf of a nation state, unless they have been specifically authorised to do so by legislation. In any case, local research institutions may not be the appropriate bodies to act as the competent national authority, given that they usually stand to gain financially from the proposed bioprospecting projects.

\section{Regulatory system}

Bioprospecting activities will often involve as many as four discrete organisations working together: a pharmaceutical company; the overseas research institution that it engages to undertake the research work; a local partner institution, and sometimes a body representing the government and/or local communities.

The regulatory system should be effective in controlling the use of genetic material after it has left the country, and is in the hands of third parties who may not have been directly involved in the collection of the material. While permits issued within a country allow the state to exercise a gatekeeper role, and provide a basis for challenging collecting activities that are not in accordance with it, they do not provide a basis for challenging unauthorised use of material once it has left the country. Collateral contract arrangements are needed to ensure that there is 
control over the use of material after it has been collected and the results of tests are passed on to the clients of the research organisation.

It may be appropriate for the access regime to provide for framework agreements setting out in broad terms the relationship between the bioprospector and the host country; for example, partnerships between local research or collecting bodies, and overseas companies seeking to benefit from the bioprospecting activities. Within the framework of these agreements, much simpler individual materials transfer agreements could be negotiated.

\section{Basis for access}

The national law or policy should set out the basic minimum terms for access but should not be too prescriptive. The process for applying for access permission should be transparent, effective and efficient.

Licensing administrative systems can easily develop a life of their own and sometimes create more problems than they solve. Minimum terms might include the following.

\section{Application processes}

- Requirement for full disclosure of information about the proposed activity (including the locality, the nature of the activity, the species to be harvested and sampling techniques to be used) and the end use to which the material will be put (in other words, a complete project proposal and plan).

- Requirement to demonstrate adequate skill and knowledge to carry out the work.

- Where it is considered viable to develop a local industry, a requirement for collaboration with a local research body may be required.

- Limits on the duration of exclusive materials transfer agreements.

\section{Collection}

- Requirement to carry out research in an environmentally sound manner and comply with environmental laws, and not to deplete local populations.

- Requirement to observe all other laws of the country in relation to collection and export, including quarantine laws.

- Requirement to enter into collecting agreements with local and indigenous communities. 


\section{After collection}

- Requirements for deposit of voucher specimens with the national herbarium.

- Requirement for academic citation in relation to published research findings.

- Access to research information (this might not realistically be required in the case of commercial agreements, but could be required of academic agreements).

- Circumstances in which information provided to the national authority can be kept confidential, and any limit on the duration of confidentiality provisions.

\section{Academic research agreements}

Academic access and intergovernmental transfer proposals are likely to involve different considerations from commercial bioprospecting ones. It may be appropriate to have a different set of requirements applying to these situations. For example, academic agreements might contain - a prohibition on obtaining any intellectual property over the material - restrictions on disposal of material and/or information to third parties. Given that there is no direct monetary benefit arising from the exchange, it may also be appropriate to limit fees so that only collectors fees (paid to local communities) are required.

\section{Research agreements/materials transfer agreements}

Within the framework provided by the access regime, research agreements or materials transfer agreements are likely to form the basis of the individual arrangements applying to specific collecting proposals. Agreements may contain a range of standard provisions including

- transfer of materials collected into custody of collector

- limitations on transfer to third parties

- whether destructive harvesting (for example, involving whole plants and bark) is permitted

- maximum volume limitations per species or overall, and provisions for extending these

- limitations on assertion of ownership over materials and genetic information

- requirements for agreement to be reached with local or indigenous communities 
- basis for entry onto private or government land

- benefit sharing, including disposition of intellectual property rights, collecting fees and royalty sharing

- term of the agreement

- whether access, either generally or to a particular area, is exclusive

- return of remaining materials on conclusion of contract

- confidentiality of information and duration of confidentiality

- mechanisms for ongoing review and monitoring of agreement

- contact persons for each party

- dispute resolution, and whether arbitration is to be used in lieu of litigation

- applicable law

- confidentiality of terms of agreement

- termination.

\section{Prior informed consent of local communities and benefit}

\section{sharing}

Access regimes are a means by which nations can ensure that access to the genetic resources within their sovereign territory occurs only with their prior informed consent and on mutually agreed terms, as required by the Convention on Biological Diversity.

However, the Convention on Biological Diversity also requires states to provide a prior informed consent regime for the indigenous people who are the owners of these resources. It is important to have a common policy on the means by which the prior informed consent of indigenous and local communities is to be sought. In many cases, a collateral materials or information transfer agreement is entered into with the group or persons who are supplying either samples or knowledge.

Sometimes an intermediary organisation will enter into collecting agreements with indigenous people on behalf of the research body which is to receive the samples. The terms of the agreement will usually include respect for local customs, procedures for obtaining consent, agreed rates for samples and/or knowledge. In some cases companies have entered into more complex arrangements that involve funding sustainable use activities by communities. It may be appropriate to limit the term of the agreement to a fixed exploration period and to provide for collateral development phase contracts if ongoing supply of a particular material is required. 
Other mechanisms can be used to gain a wider range of views on a proposal. These include public notification requirements and holding research proposals in a public register. However, these systems are expensive to operate and should not be adopted without careful consideration of the resource implications.

\section{Possible monetary benefits}

Monetary benefits payable under an agreement will vary from case to case. Some of the kinds of monetary benefits that are typically included in agreements are

- upfront payments

- collection fees

- share of royalties in event of commercialisation

- know-how licence fees

- support for in-country researchers or institutions.

Sample fees are usually paid to indigenous communities. Typical amounts for collection payments are reportedly between US\$50-200 per kilogram of raw material, depending on the difficulty involved in collection (Laird 1993:108-9).

An issue for serious consideration in the access regime is the proportion and mechanisms for distribution of royalty shares in the event of a marketable discovery. While those groups who have provided the initial sample may assume that they are entitled to receive royalties, this may not be an equitable outcome, in particular if the species has a widespread distribution. The identification of all the range of owners of a particular species is probably an impossible task. It may be more appropriate to consider mechanisms that give all resource owners in the country access to a pool of these funds for specific purposes, for example, activities that support and reward biodiversity conservation.

\section{Possible non-monetary benefits}

A review of existing access arrangements suggests that non-monetary benefits are the most important form of compensation flowing from access to genetic resources. These include

- mutual exchange of material

- improvement of genetic stock

- information exchange 
- joint research

- technology transfer and training

- institutional capacity building

- joint venture

- deposit and identification of specimens.

\section{Benefit sharing}

Some of the most important negotiations that will occur under any access regime relate to the benefits that flow back to the country which provided the material. There are a number of possible beneficiaries including

- the competent national authority - to cover the costs of administration

- any intermediary organisation, such as a university-to cover the costs of their involvement and promote research

- conservation activities-to maintain the resource that is generating the income

- (depending on the constitutional structure) sub-national government

- resource owners and local communities (Para 3, Contract Guidelines: Appendix 2).

The Manila Declaration provides some guidance about suggested division of proceeds between different bodies involved in a collection process. It suggests that

- '60 per cent of any income arising from supply of extracts to commercial organisations should be returned to the appropriate country organisation'

- the country organisation should receive ' 51 per cent of any royalties arising from external collaboration that results in marketable products' (a fair royalty is suggested to be of the order of 3-5 per cent) (Para 4, Contract Guidelines: Appendix 2).

Benefits, and the arrangements for their distribution, are likely to vary considerably between different agreements.

\section{Mechanisms for distributing benefits}

Distribution of benefits to resource owners is a difficult issue in any context. Where payments are made for samples collected, the issues are comparatively simple. Individuals and families who supply material are paid at the agreed rate. Where communal knowledge is accessed, or where royalty shares are being distributed, the arrangements for 
distribution are likely to be more complex. Incorporated land groups or agency arrangements may be an appropriate mechanisms. Trust arrangements could also be used, although at least one commentator has criticised the use of trusts on the basis that they are a culturally foreign concept for indigenous people (Simpson 1997:157).

\section{Future directions}

Countries that are looking to develop a more formal approach to allowing access to their genetic diversity have a wide range of information available to them. Unfortunately, not much information is collected together in an accessible form. Websites, publications in technical journals and a handful of text books are available. A number of international and regional bodies are developing an expertise in this area. They include the International Union for the Conservation of Nature, World Wildlife Fund, Working Group on Traditional Resource Rights and the Malaysian-based Third World Network. A substantial amount of work has also been done by the African Centre for Technology Studies, based in Nairobi.

The range of examples of other countries' experience in developing access regimes should be carefully evaluated. Many of the countries who have enacted access laws already have quite sophisticated administrative systems and more resources than small Pacific island nations. The suitability of their models should not be automatically presumed. However, they may offer a useful basis for developing a simpler, more streamlined and cost-effective approach.

Within and outside government there are a wide array of stakeholders whose interests need to be accommodated in developing a system for regulating access. These include

- biologists and biological research bodies

- forestry regulatory authorities and research bodies

- forest industry representatives

- environment protection and conservation authorities

- agricultural research bodies and industry representatives

- organisations working in the non-government sector with an interest in conservation and rural development

- local and indigenous communities and sub-national governments. All these stakeholders will be required to participate in effective implementation and their acceptance of its suitability to their needs is essential. 
A strategic plan for the establishment of an access regime (including the development of model access agreements, establishment of a competent national authority and so on) should be developed. A strategic plan should help to identify the cost implications of the proposal and ensure that it will possible to implement it.

The importance of regional coordination of efforts to establish access regimes cannot be underestimated. Some of the possible benefits of regional cooperation are

- economies of scale in terms of researching and evaluating different models

- developing a respository of regional expertise

- adoption of complementary systems to clarify and simplify access for prospective prospectors and encourage compliance

- the provision of a mechanism for regional cooperation in relation to access to regional endemic species.

\section{Conclusion}

The debate in Papua New Guinea about how to protect sovereign interests in genetic resources has so far concentrated mainly on intellectual property rights. Some of the discussion is misinformed. For example, the suggestion that a wide variety of species of animals and plants could be patented is unrealistic in view of the cost of obtaining patents. In any case patents of this kind would not conform to the international standards for patent law because products of nature are not patentable unless they are a new variety produced through artificial breeding. Rather than whole species, the issues about intellectual property rights relate to processes and products that have been developed on the basis of information obtained from genetic material.

Intellectual property law is a complex and highly specialised area. Its application to biotechnology and pharmacology is even more complicated and specialised. It is important that the debate in Papua New Guinea be informed by those who are knowledgeable about these areas so that the issues are understood in their proper context.

This chapter has considered the issues involved in establishing a system for protection that does not rely on intellectual property rights. Instead, it works on the basis of a gatekeeper mechanism. Quite simply, access to biological resources would not be allowed except on certain terms and conditions dictated by government, including terms relating 
to the intellectual property (and benefits from its use) arising from any discovery made in Papua New Guinea.

Instituting a system of controlling access is a relatively simple matter legally, but has significant resource implications. It is probably beyond the capacity of existing government agencies to operate such a system effectively. Furthermore, the task of regulation becomes more complicated when issues of indigenous rights are considered.

The mechanisms by which indigenous owners of biological resources (not just in the location where they are accessed, but everywhere in Papua New Guinea) are involved in decision making, and share in benefits, are likely to involve a substantial infrastructure. These issues challenge Papua New Guinea's community and policymakers to think creatively and laterally about how to do much more with much less, perhaps through the involvement of agencies outside government in partnerships to implement the new regulatory mechanisms.

In the thick of this debate, it is important not to lose sight of the final goal (in the words of Papua New Guinea's Fourth National Goal): 'to secure the conservation of natural resources and the environment for the collective benefit of future generations'. One thing is certain: without some intervention, however indequate, the current generation will fail in its challenge to secure the future for its children.

\section{Notes}

1 An earlier version of this paper was presented to the Conference on Plant Genetic Resources, Apia, Samoa, April 1999. The author wishes to thank Clark Peteru for his comments on the earlier version. Errors and omissions are the author's responsibility alone.

2 Prior informed consent provisions are used in a number of other international conventions, including the Basel Convention on the Transboundary Movement of Hazardous Wastes. It has been suggested that a prior informed consent regime would require full disclosure of the reasons for the activity, the specific procedures involved, potential risks and the full implications that can reasonably be foreseen (Fourmile 1998:15 and note 11).

3447 US 303 (1980) (Huft n.9 and Peet). 
4 In the early 1990s the National Institute of Health filed a patent application for copy DNA sequences resulting from research conducted by its biochemist as part of the Human Genome Project. The sequences included some obtained from Hagahai people in the Highlands of Papua New Guinea. See Moufang (1994) for a full discussion of the ethical issues.

5 The Code of Conduct appended to the Manila Declaration suggests that a maximum of 500 grams of dry weight should be provided initially, although Laird (1993:108) suggests that more is now usually required. 


\section{1 \\ The search for an interim solution}

\section{Brendan Tobin}

The role of scientist, scholar and lawyer should be to provide information and ideas, not to undertake the redefining of intellectual property rights. That should occur as the result of practice and experimentation by local communities. One thing is certain: the concept is not defined, and indeed, should not be defined in the immediate future (Posey 1994:240)

In September 1996, following a prolonged negotiation process lasting nearly three years, organisations representing the Aguaruna people of the Peruvian Amazon signed bioprospecting agreements with Washington University and the pharmaceutical arm of the Monsanto corporation, Searle and Company. The agreements provide for the collection and use of medicinal plants and associated traditional knowledge in the research and development of new pharmaceutical products.

The framework for negotiating the agreements was provided by the International Collaborative Biodiversity Group, ${ }^{1}$ which seeks to encourage the establishment of consortia of private sector, academic institutions and local actors for the research and development of new products through sustainable use of genetic resources. The agreements use a traditional contractual format, but in an innovative way and with the inclusion of novel terms and conditions. Their main aim is to secure indigenous peoples constant control over the collection and use of their knowledge, innovations and practices throughout the process of commercial research and development. Negotiation of the agreements involved finding a means to overcome some of the most controversial elements of the natural resource trade. 
Of particular importance in establishing these arrangements was the recognition of the reduced lead time which use of indigenous knowledge signifies for research and development activities. It was decided that the knowledge should be the subject of a specific know-how agreement, providing for an annual licence fee and advance royalties. The annual licence fee would be payable throughout research and development activities, and advance royalties would be paid in accordance with a schedule of milestones linked to clinical trials and new drug applications.

The agreements take the form of a contract for the collection of biological material and a separate know-how licence for use of indigenous knowledge. They were drafted in this way to prevent the acquisition of monopolistic rights, which might be used to limit the capacity of indigenous peoples to continue to use, share or market their biological resources, medicinal products or knowledge. It also secures recognition of the right of indigenous people to be compensated for use of their knowledge even where that knowledge has fallen into the public domain.

At the time these agreements were negotiated, there was no legislation in Peru governing access to genetic resources, or a regime to recognise and protect indigenous collective property interests. Given these constraints, the agreements are far from perfect. The process of their negotiation has, however, catalysed action by national authorities to draft and circulate legislation for the establishment of a sui generis regime for protection of collective property. This draft proposal will implement the provisions of Article 64 of Peru's new industrial property law, adopted in May 1996. This law gives the Ministry of Industry the power to adopt a special regime to protect the rights of indigenous peoples over their knowledge, including, if appropriate, the establishment of a register of knowledge interests.

This chapter is an attempt to draw some conclusions about potential mechanisms for protecting indigenous rights. It is based on experience gained while participating in the negotiation of the International Collaborative Biodiversity Group contracts, as legal adviser to the Aguarunas; and while serving as a member of the national working group for the development of legislation for a sui generis regime to protect indigenous collective property. The chapter examines a proposal, of which the author has previously been a sponsor, to use intellectual property regimes as a way of ensuring that prior informed consent becomes a condition for commercial use of traditional knowledge. 
The search for mechanisms to protect indigenous peoples' rights should begin from the position that any solution must come from indigenous peoples themselves. At present therefore, the most that can be achieved is the development of interim mechanisms that prevent the continued erosion of indigenous control over their collective property. Mechanisms of this kind should seek to provide indigenous peoples with the means to regulate use of their resources in a manner that ensures protection for present and future generations, and to secure equitable sharing of benefits derived from use. With that in mind, the proposals below may be seen as potential preliminary steps on the long road to equity.

\section{Issues in developing regimes for indigenous and collective property rights}

A technical discussion of how to protect rights over local and indigenous community knowledge must start from an understanding of what is to be protected, the nature of the material, its ownership, who would protect it, and against whom protection would be enforced. It must also consider the reasons why protection is being granted. Is it to prevent use, stimulate the market or promote innovation? If the means is to achieve the end, it is important to clarify these issues before developing the mechanism for protection. If, for example, indigenous communities primarily seek financial reward, then the approach adopted must be one which maximises returns. If, on the other hand, the main objective is to prevent unapproved use, or to impede use altogether, then a strict and demanding access regime might be what is sought.

\section{Elements of an access regime}

Analysis of the writings of commentators is helpful in identifying some fundamental issues that must be included in any regime to protect indigenous and local community collective property. The following features appear among the most widely identified objectives for an access regime

- ensure recognition of the collective nature of the knowledge, both within and among generations of indigenous peoples

- ensure that control of the use of knowledge remains firmly in the hands of indigenous peoples, even where such information is found within the so-called public domain 
- ensure that the exercise of rights by any community, group of communities, people or peoples does not infringe the rights of other communities or peoples to use, dispose of or otherwise control their resources

- avoid creating monopolistic rights over knowledge, and prevent the possibility of the acquisition of monopolistic rights over knowledge or the biological resources with which it is associated

- ensure equitable benefit sharing within and among communities

- assist in the revaluation of indigenous knowledge, promote traditional use and minimise adverse impacts on resources and cultures

- establish a presumption that the use of resources over which there exists knowledge, in particular regarding medicinal plants, implies use of that knowledge.

These objectives reflect the interests of the custodians of knowledge. In an ideal world the solution adopted would ensure complete compliance with these goals. But given practical realities, it is also necessary to consider a number of other questions. For instance, what capacity do national authorities have to establish a mechanism that can ensure realisation of these objectives? How can transaction costs be kept down? (If the system is too expensive benefits will end up being consumed by maintenance costs and will not reach communities.)

There are also important questions about dealing with rights on behalf of a collective. Can all communities and custodians of relevant knowledge be identified, and if so, is it feasible that they all be required to give consent for its use? What happens when these communities live in neighbouring countries? How can the use of material in the public domain be prevented? How can equitable sharing of benefits within communities be achieved without being paternalistic? How can sharing among communities, in particular those that do not have a history of cooperation, be achieved, again without resorting to paternalism? In what form should information be held in a register, and for what purpose? If the value of the knowledge is in keeping it confidential, how can the system ensure that potential users are aware of the identity of communities that must be consulted about the use of knowledge?

Coupled with these questions-about communities and their relationships with each other and government-are other questions about the role of private sector actors. With whom should they negotiate? Options include the whole community, custodians of particular knowledge or shamans, healers or leaders. How can legal certainty be secured so that the company is protected against future 
claims brought by other custodians of knowledge following development of an interesting product? Should warranties be sought from indigenous peoples regarding their right to enter into agreements? Can indigenous peoples be required to accept confidentiality obligations regarding research and development reports, and if so, will they be in a position to comply? To what extent are companies responsible for ensuring equity in distribution of benefits within and amongst communities? Should companies be obliged to pay royalties after patents expire? What happens when competitors are not paying royalties for information in the public domain? Is it fair that companies who entered into agreements should be prejudiced in competition with companies that are not paying royalties?

These questions identify only some of the significant issues to be taken into consideration in the search for an adequate and functional regime to protect knowledge rights. Although many articles have addressed the lack of adequate protection, and the inadequacies of existing intellectual property regimes, to date only a handful of proposals have been circulated which offer potential solutions to the problem.

\section{Sui generis systems}

The major proposals made so far, other than those which identify limited possibilities for use of existing intellectual property rights regimes, have focused primarily on development of sui generis protection and on the modification of reporting requirements under existing intellectual property rights application procedures. Although there appears to be a belief in some quarters that they are mutually exclusive, it is suggested here that an approach which incorporates both sui generis regimes and modification of existing intellectual property rights regimes may prove most appropriate. The former provides an avenue for recognition and protection of indigenous rights, and facilitates their exercise, and the latter serves to limit the possibilities for unapproved use of indigenous and local community resources in importing countries.

\section{History of development of alternative models}

The two major influences on the sui generis debate are the well known works of Gurdial Singh Nijar (1995) and Darryl Posey (1996a). Nijar's proposal for a collective property register, which has been circulating for a number of years, would entitle indigenous peoples to register their 
knowledge and utilise registration to control commercial use. Posey, on the other hand, focuses on an array of existing rights that together provide for recognition and protection of what he terms traditional resource rights. His model seeks, through recognition of a bundle of rights, to ensure the most comprehensive respect for, and protection of, indigenous and local community interests. However, Posey's proposal does not presume to provide the format for a system of protection. Rather, it identifies existing regimes each of which, when treated in unison, provide for recognition of and protection for indigenous rights.

While any regime should be developed with close attention to the bundle of rights Posey has identified, a mechanism must be found that can be applied as soon as possible to address the increasing uncompensated, unapproved use of indigenous knowledge, innovation and practices. For this purpose a more specific proposal regarding the format of legislation to recognise rights is required.

Nijar's proposal provides a basic format around which such a rights regime might be structured. The underlying principle that community rights can be recognised, registered and defended against unapproved use, while not impeding traditional transfers, is alluring. However, while $\mathrm{Nijar}$ proposes that these rights should be non-monopolistic, the right to impede commercial use does carry monopolistic connotations. Furthermore, while his proposal suggests a right that can be defended against abuse by third parties, he does not explain how local and indigenous communities could monitor international product development and intellectual property rights applications in order to control unapproved use of resources.

A third difficulty, and one that is common to the whole debate about indigenous rights, relates to the treatment of prior informed consent. This concept expresses the desire to ensure that all communities who share knowledge approve of its use. However, except where a number of communities share a commonality of purpose, this kind of approval would be all but impossible to secure. This is true even if it were possible to identify all the custodians of the relevant knowledge. A proposal that requires consent by all communities could effectively serve as a veto over the exercise of collective property rights, even by a majority of the communities' custodians of traditional knowledge. While this may be considered desirable in some cases (for example, to prevent cultural disintegration), it does not overcome the continuing problem of unapproved use, nor does it necessarily conform with the dynamic 
nature of indigenous societies and their right to adapt to development opportunities. Furthermore, it fails to respond to their need to find a means to protect their cultures in a globalised economy. The requirement for unanimous consent may even conflict with traditional decision making practices of many indigenous peoples, which might include weighted voting powers of elders and other important members of the society, or a form of majority decision making.

Despite the possible limitations of Nijar's proposal it does provide a good starting point for discussion of a mechanism for protection of indigenous interests. The tension between recognition of rights to prevent use and adoption of a non-monopolistic philosophy are not insurmountable. His proposal cannot, however, stand alone. It must be incorporated into a wider regime which includes international as well as national control mechanisms. If such an approach is taken, then freedom for indigenous and local communities to exchange information, in accordance with time honored non-monopolistic values, may be maintained.

In summary, a comprehensive collective rights regime would include both a sui generis national regime and a multilateral agreement for conditional use of knowledge, based on demonstrated prior informed consent for such use.

\section{Suggested elements of a sui generis regime}

The following proposal is a list of the principal elements that should be considered in the establishment of any collective rights regime. It is not intended to be exhaustive, and the principles set out below might be most appropriately considered as minimum conditions.

Inherent nature of the rights. The rights of indigenous and local communities over the product of their intellectual effort stem from their development of knowledge, innovations and practices and not from any act of government.

Rights may still exist in public domain material. Indigenous rights over knowledge, innovations and practices exist whether or not the information is considered to be within the public domain. The fact that information may be freely distributed by indigenous and local communities should not be seen as impeding their right to limit its use for commercial or scientific purposes, or for uses which are otherwise contrary to their spiritual or cultural morals. All prospective users must therefore be required to seek and obtain the prior informed consent of custodians of traditional knowledge. 
There is a commonly held misconception that material in the public domain cannot be the subject of intellectual property rights. However, within the United States, European Union and Japan there are examples of material that is protected in the public domain, including writings and designs. These experiences, which in the case of Japan and the European Union occurred within the last decade, are likely to be precedents for further efforts to protect public domain material. Similar protection of indigenous knowledge is therefore a possibility.

Cultural patrimony. The traditional knowledge rights of indigenous and local communities are collective in nature, both inter and intragenerationally, and should be recognised as cultural patrimony. ${ }^{2}$ These rights therefore cannot be alienated.

Distinguish indigenous rights from national sovereign rights. Where biological resources are considered national patrimony, there should be a clear distinction between the rights of the state over these resources and the collective property rights of indigenous peoples over their knowledge, innovations and practices. During the International Collaborative Biodiversity Group negotiations it was decided to adopt a contractual regime which clearly separated the benefits received for use of biological resources from the benefits received for use of knowledge. This was done to avoid the possibility of state intervention in benefit distribution, because of concerns that this would lead to an exhaustion of benefits in administrative overheads.

Intellectual property rights should not be monopolistic. Agreements for use must ensure that any intellectual property rights obtained by users cannot be utilised to prevent traditional use, or the sale, licensing or use of knowledge, innovations or practices, in any part of the world. They should also ensure that any rights (including patents) that are obtained on the basis of indigenous knowledge cannot be used to prevent the use, sale or licensing of those resources in any part of the world.

In many cases, agreements will not include all the custodians of particular knowledge. For example, on the Peruvian-Ecuadorian border five distinct indigenous tribes, all belonging to the Jivaro ethnic grouping, hold much of the same knowledge. It is important that an agreement such as the International Collaborative Biodiversity Group Peruvian agreement, which involved one of these tribes, the Aguarunas, should not prevent the other tribes from benefiting from their knowledge.

It is also important to ensure that compositional matter patents obtained by companies are not used to prevent the use or sale of 
medicinal plants containing the patented matter. Cases may arise where a company finds and patents compositional matter for a specific anticancer end. For example, it is very possible that if an indigenous people were to sell their medicinal plant within a protected market, with allusion to its anti-cancer properties, the sale could be challenged as a breach of the compositional matter patent.

Ownership of knowledge should be presumed from use of resources. The regime should establish a legal presumption that use of biological resources presumes ownership of knowledge about the properties of those resources. This presumption should operate where resources have historically been used by indigenous peoples or local communities for medicinal, biopesticide, phsycoactive or toxic purposes; or where the important characteristics of cultivated resources are confined to cultivars in clearly identifiable ecosystems. In such cases the rights to use the resource should be dependent on the user having a valid license to use the related knowledge.

Licences should be non-exclusive. While it is desirable that prior informed consent should be sought from all custodians of knowledge, innovations and practices, this may be impossible in many cases, at least for the moment. As such it is considered preferable that any contract or licences for the use of collective property should be of a non-exclusive nature. ${ }^{3}$

Review procedures. Any regime that recognises collective rights should establish administrative and judicial review procedures that allow custodians of knowledge, who are not party to an agreement, to challenge agreements for use of such knowledge in clearly defined circumstances. Challenges of this kind should be permitted on the basis that

- the contracting community or people are not legitimate custodians of the relevant knowledge

- benefit sharing is inadequate

- commercialisation of knowledge would undermine the culture or the people, or run counter to their spiritual beliefs

- commercialisation could lead to genetic erosion, loss of access for traditional uses or lead to undesirable incursions onto indigenous territories.

Equitable benefit sharing. The regime should establish mechanisms to secure equitable sharing of benefits among all custodians of collective property, whether or not they are parties to a contract for its use. The Peruvian International Collaborative Biodiversity Group project requires 
the participating indigenous organisations to establish a mechanism for distribution of benefits which will ensure equitable distribution among all Aguaruna and Huambisa peoples, whether or not they are party to the agreement. It is envisaged that a form of trust fund may be established, with representatives of the five river basins inhabited by the Aguarunas and Huambisas on its management board.

Benefits should be administered by indigenous peoples themselves. However, as this is collective property, it will be necessary to ensure that benefits are distributed in a transparent fashion and that the interests of future generations have taken into consideration. The commercial value of traditional knowledge may be exhausted once patents obtained over derivatives of medicinal plants have expired. To this extent custodians have an obligation to ensure that benefits received are used to the advantage of both present and future generations. Investment in development projects, securing land and resource rights, conservation of the environment and strengthening traditional knowledge systems are all avenues by which benefits may be more equitably distributed over generations.

The state has an obligation to promote equitable benefit sharing in accordance with the Convention on Biological Diversity. Indigenous peoples should be advised that if they fail to ensure equitable benefit sharing with other custodians, the state may intervene.

Register of collective property. The regime should provide for a register of indigenous and local community collective property to assist national authorities in determining which communities, or peoples, should be informed and consulted regarding proposed contracts for the use of their collective property, and among whom benefits should be shared. This register would only be declaratory, and would not purport to define which communities have rights. No benefits should accrue to those communities who are registered, beyond the benefit of their identification-to the government and potential users-as interested parties.

\section{A multilateral system to secure prior informed consent}

Any national regime is, by its nature, restricted in its application to the territory within its jurisdictional boundaries. The major commercial markets in which infringements are most likely to occur are generally located in countries other than those from which the knowledge and resources were sourced. The economic and logistical difficulties which indigenous and local communities face in policing the use of their 
collective property limits the effectiveness of any regime which requires custodians to monitor and challenge abuses of rights.

For these reasons, it is proposed that any national regime should be complemented by a market-based mechanism that would reverse the burden of proving the right to use a resource. At present, applicants for patents and other intellectual property rights are not required to demonstrate their right to use the knowledge or resources on which their application is based. Instead, indigenous groups who seek to challenge patents must establish that the applicant does not have that right. It is proposed to reverse this onus, and to place the burden of proving the right to use knowledge or resources on the user, rather than on the country of origin or its local and indigenous communities.

While the idea of using the market as a means to prevent 'biopiracy' is seen by some commentators as the tip of the iceberg through which collective property would eventually be expropriated, an objective consideration leads to a contrary conclusion. In fact the proposal for certificates of origin set out below should not be seen as one which will convert collective property into a negotiable commodity of itself. On the contrary, what is promoted is a mechanism which ensures that, where use of knowledge, innovations and practices has not been the subject of prior informed consent, the opportunities for the user to commercialise any resultant product or process will be severely limited.

Adopting the premise that indigenous and local communities are mainly concerned to prevent the unapproved use of their knowledge, including in some cases any form of commercialisation, the following proposal is directed toward controlling these activities. It is based on an assumption that the desire to access and use knowledge is directly proportional to the potential commercial return to the user. Limiting the possibilities of commercial reward for unapproved use should in turn induce users to seek prior informed consent. It should therefore be seen as an instrument of control rather than an aid to commercialisation.

\section{Incorporating prior informed consent into existing}

\section{intellectual property rights systems}

The ability of a company to make money from a product or process, and therefore their willingness to invest in research and development, is closely linked to the security of intellectual property rights protection. Increasingly, profit potential is also linked to product approval processes 
supervised by national and international standards organisations. The existing regimes for product approval and intellectual property rights have developed over many years. They have been the subject of intense debate, which continues to the present and is likely to continue. The principles underlying these regimes are the subject of divergent views. They are considered by many to be doctrine, by others to represent the evil of capitalistic monopolisation. Given these polarised viewpoints, it seems unlikely that the fundamental tenets of these regimes can be altered, at least in the short term.

The proposal described below seeks to avoid becoming enmeshed in that greater debate; rather than challenging the substantive elements of existing regimes, it focuses on modifying their application procedures. This approach has the additional advantage that, if it is agreed on, it could be implemented by national authorities and standards bodies through administrative rather than legislative means, thereby offering protection in the short rather than the long term. Furthermore, these proposed modifications would still meet the requirements of Article 27 of the Trade-Related Aspects of Intellectual Property Agreement, so no modification of that agreement would be needed to implement it.

Numerous commentators have come to the conclusion that requiring identification of the source of genetic resources and knowledge in patents would help to bring their use to the attention of their custodians. This common view has emerged from a number of individuals whose thinking developed separately in different parts of the world. This convergence of opinion tends to suggest that, not only is a market-based tool a valid option, it is probably the most practical mechanism for monitoring and controlling use of knowledge.

Identification of genetic content and use of knowledge in a patent does not necessarily deal with the issue of prior informed consent. The restrictions which indigenous and local communities will face in policing the use of their resources and the costs of challenging an intellectual property rights grant must also be taken into account. The system must go further and provide for evidence of the right to use the knowledge or resources. This is most effectively achieved if there is a reversal of the burden of proving the right to use knowledge, from the custodian of that knowledge to the user. In this way the intellectual property rights system can employ market tools to regulate use for the market. 


\section{Elements of a certificate of origin scheme}

The following core elements for a certificate of origin scheme are suggested. ${ }^{4}$

Declaration as to the right to use resources. A certificate of origin scheme would require that applicants for patents and other intellectual property rights make a sworn declaration regarding the use of genetic resources and associated knowledge, and provide evidence of their legal right to use such resources for the production of the material for which intellectual property rights protection is sought. Similar requirements could also be included in product approval procedures.

The Food and Drug Administration and the International Standards Organisation, for example, could make it a condition for receipt of applications that evidence of prior informed consent be included. As many products are not subject to patents but are commercially exploited on an industrial scale it is important that mechanisms be used which allow the control of all major commercialisation of genetic resources, collective property and products developed with use of such resources. This requirement would effectively transfer the burden of securing the interests of countries of origin and of indigenous and local communities to the user. This may be likened to the reversal of the burden of proof concerning production of a product over which there exists a patented process, found in many jurisdictions and as included in the TradeRelated Aspects of Intellectual Property Agreement.

Certification of origin. Evidence of the right to use resources could be given either by production of a contract or licence to use the knowledge, or in the form of a certificate issued by the competent authority of the country where the custodians of the knowledge reside. This certificate would include the names of the parties, the tangible and intangible resources being provided and the rights and limitations placed on the user. As in many cases access to knowledge will be linked to access to specific resources, the certificate could cover both knowledge and resources.

Uniform international system. A certificate system common to all nations would help to harmonise procedures and prevent the need to interpret different contract provisions under differing legal regimes. Reid and La Vina (1995:10) argue that harmonised national standards and requirements for biodiversity trade would lessen the hurdles facing users of biodiversity. They suggest that a certification system established in 
conjunction with national standards would help to reduce the illicit trade in genetic resources.

A uniform international system would also protect commercial confidentiality of sensitive contract details not required by the patent authorities. A uniform and recognisable certificate would obviate the need for patent offices to verify the nature of the consent given, a role which they should not be required to perform.

\section{Conclusion}

Although it is desirable that any regime to protect indigenous and local community interests be drafted by indigenous peoples, some form of protection is needed in the short term. A blend of national and international measures will be necessary to ensure comprehensive and effective protection. By recognising rights at the national level, and impeding use of knowledge for commercial purposes through a multilateral agreement requiring countries to modify intellectual property rights and product approval application procedures, an interim mechanism can be established which would effectively prevent unapproved commercial use of knowledge.

The Conference of the Parties for the Convention on Biological Diversity should be asked to establish an ad hoc experts group on collective property, with a mandate to consider possibilities for adoption of an international accord on indigenous and local community knowledge rights. This group must include representatives of indigenous peoples and should commence a global participative process to determine the format that such a regime should take. 


\section{Notes}

1 The International Collaborative Biodiversity Group Peru project is one of five projects worldwide financed by the US National Institute of Health, National Cancer Institute and the National Science Foundation. For further reading on the International Collaborative Biodiversity Group Peru Project and the agreements associated with it see Tobin (1997b).

2 Article 24 of the new Peruvian Law on the Conservation and Sustainable use of Biological Resources, Ley No. 26839, adopted on 27 July 1997, recognises that the knowledge, innovations and practices of indigenous peoples are their cultural patrimony and that they hold rights over it and are entitled to decide over its use.

3 It is possible that a specific community or group of communities have a body of knowledge which is not shared with other indigenous peoples, and that all the custodians agree to give an exclusive right to a particular user. There may be good commercial reasons for doing so, as well as reasons relating to maintenance of control over the knowledge. In such an instance exclusivity may be appropriate in so far as the rights are granted under licence, may be revoked for noncompliance and do not preclude future generations from utilising the knowledge to their benefit.

4 For a comprehensive bibliography and further reading on certificates of origin see Tobin (1997a). 


\section{Appendix}

\section{summaries of small group discussions}

\section{Discussion group 1: John Sengo presenter}

How can Papua New Guinea most effectively assert its national sovereignty over biological and cultural resources within its borders?

The group considered the question of sovereignty over the sustainable use of biological and cultural resources within communities including the sovereignty of the national government, provincial governments, local governments and local communities over their resources. The group felt that asserting sovereignty is important to prevent and/or control exploitation of national resources for profit by both in and outof-country researchers and developers. In addition, Papua New Guinea should allow access to its resources only under certain conditions. In all circumstances, ownership of resources by local people must be recognised along with their sovereignty over those resources.

\section{Group recommendations}

- In the absence of legislation and accompanying rules and regulations, policies protecting cultural and biological property rights should be developed and implemented. Education and awareness activities should be conducted throughout the country to teach people about their biological and cultural property rights. In this way, the local custodians of land, knowledge, and traditions will become aware of their rights and the importance of protecting 
their resources. Education and awareness activities should a) encourage people to document their biological and cultural knowledge, and b) create places to store this information to prevent its loss. It is important that traditional knowledge does not disappear with the people who possess it; while it is a good idea to publish it, that does not necessarily include selling it. It is most important to keep a record of it.

- A working group should be created to look at existing legislation in order to a) determine how it could be improved to effectively protect sovereignty over biological and cultural property, and b) develop any additional rules and regulations needed to meet desired levels of protection for biological and cultural property rights. With this in mind, it was proposed that the existing copyright law should be implemented, but that patent law should be considered more carefully and drafted only when its implications to Papua New Guinea are thoroughly understood. In addition to enacting copyright law, access legislation to implement the Convention on Biological Diversity should be drafted, and profit-sharing mechanisms based on the potential for commercial development of biological and cultural resources should be crafted.

- A working group should be established to develop a code of conduct for researchers in Papua New Guinea. Such a code of conduct should provide guidelines to access cultural and biological property and can be used in advance of developing new legislation. A monitoring scheme also should be developed to evaluate implementation of a code of conduct.

- Access agreements should be signed before any access to biological and cultural resources is provided. Such an agreement should require negotiation of access on a case-by-case basis before access occurs, and should emphasise that cultural and biological resources are owned by local people and that there will be no access to resources without this recognition and understanding. In addition, access agreements should include provisions for in-country counterparts-individuals or institutions-and for benefit-sharing information should commercial exploitation result.

\section{Questions}

How much can be protected by copyright? For example, who and how do you protect in a situation where someone records an oral legend? The 
original author or the recorder? Can we develop a community copyright and patent?

In some countries people have asked that none of this information be published until there is a mechanism in place to deal with this issue. It may also be useful to put a notice in the beginning of published material to indicate that by reading the material the reader has accepted the terms of its license, that is, that the information contained within is derived from indigenous people and if the reader wants to use it she or he must get permission from and provide some benefit to the originators of the information. The most fundamental question is that of ownership and the issue of collective versus the private ownership of knowledge. Can one be transformed into the other and if so, how?

\section{Group members}

Paz Benavidez, Department of Environment and Natural

Resources, Philippines

Herman Buago, Law Reform Commission

Dr Michael Alpers, Institute of Medical Research

John Sengo, Foundation for the Peoples of the South Pacificl

Papua New Guinea

Dr Colin Filer, National Research Institute

William Edoni, Summer Institute of Linguistics

Moses Kumbundu, Blakes Lawyers

\section{Discussion group 2: Nick Araho presenter}

\section{What types of intellectual property protection should Papua New} Guinea implement, if any, and what types of information should they protect?

This discussion group raised many interesting issues came up which did not directly answer the question but were important concerns. The group began by asking 'What do we want to protect?' and divided the question into biological issues and cultural issues. The objective of protection generally focused on the conservation of cultural traditions and safeguarding biological resources from the misuse and destruction by others. However, this does not necessarily mean that resources shouldn't be exploited. It was recognised that the type of protection desired would depend on the type of information at issue. 
Protection of culture was viewed as important to preserve cultural identity and knowledge, to sustain traditions, to prevent misrepresentation and misunderstanding, to revitalise and redirect Papua New Guinea's youth, and to gain benefits from the use of culture. Not only would those currently living in Papua New Guinea benefit, but future generations, in and out-of-country researchers, and other cultures throughout the world would benefit from cultural safeguards. Threats to culture include researchers, missionaries, oblivion and misrepresentation by individuals or institutions. The group noted that culture itself is constantly changing and therefore it is important to recognise that it can't be preserved as a static entity; rather the relationships embedded in culture must be protected and its fluidity accepted.

Protection of biological resources was viewed as important to ensure the sustainable use of resources, to prevent overexploitation, to study and understand the resources for the future, and to gain benefits. The group was concerned about the exploitation and destruction of biological resources by farmers, developers, and resource owners. The group expressed a need to protect biological resources for future generations, farmers, researchers, and for the planetary ecosystem.

\section{Recommendations}

- Borrowing information between groups characterises Papua New Guinea; nobody should interfere with that. The sharing of information in Papua New Guinea only requires permission or the exchange of certain gifts. Thus, no actions should be taken that might stop the flow of information exchange through traditional channels. It is important to continue to be able to borrow and share from other Papua New Guineans.

- The group questioned whether international treaties regarding intellectual property will be useful or detrimental to Papua New Guinea in the short and long-term. They are constructed from outside Papua New Guinea by developed countries and revolve around commercial value. It may be more appropriate to develop mechanisms to control the exploitation of commercial endeavors and to control the exchange of information and resources in Papua New Guinea rather than begin legislating these issues right away. Establishing some type of mechanism to regulate entities from 
outside who want to use information originating in Papua New Guinea for commercial value is where we need to focus now.

- Customary law in Papua New Guinea is an important concept. It responds to and has the potential to resolve a lot of concerns at the village and local level. People shouldn't forget about this when considering mechanisms to regulate the exchange of information because it can be useful to resolve conflicts related to information exchange in villages and towns. The use of mediation to determine just outcomes is a feature of customary law; this isn't taken into account in statutory law. Thus, we should pay careful attention to the role that customary laws can play in Papua New Guinea.

- Whatever mechanisms are developed to regulate the exchange of information in Papua New Guinea, they must be reciprocal and ensure that information comes back into Papua New Guinea to help people in villages. For example, people who come to Papua New Guinea to do research should provide the results of that research to the village and explain what it means and why it is important. In this way the value of this information will be increased because it will have value to local communities and its reciprocal exchange will create the potential for partnership ventures.

- The definition of property under most legal regimes, and particularly in international treaties and conventions, is a western concept. It is vital to figure out what the characteristics of property are in Papua New Guinea and to work within our particular cultural framework.

\section{Questions}

Why should we focus exclusively on information exchange with outside entities when we can also be manipulated from within?

We should be more concerned about outsiders because they have more power/money and therefore a greater potential to use us to their own advantage without any recourse. Within our own system we have the advantage of checks and balances to help us work out internal problems of exploitation.

\section{Group members}

Nick Araho, Papua New Guinea National Museum

Marilyn Strathern, Cambridge University

Leslie Harroun, Conservation Melanesia 
Rick Bein, Papua New Guinea University of Technology

Colin Filer, National Research Institute

Balthasar Wayi, Department of Agriculture and Livestock

Joseph Turia, National Cultural Commission

John Genolagani, Department of Environment and Conservation

Seline Leo, Department of Foreign Affairs and Trade

Otto Anduari, Department of Education

Brother Andrew, SSF, Melanesian Institute

Senea Greh, Papua New Guinea National Museum

Roselyn Kenneth, National Research Institute

\section{Discussion group 3: Randy Thaman presenter}

What mechanisms can Papua New Guinea employ to recognise and protect indigenous knowledge, art, and practices that respect their collective (or individual) ownership and origin?

The group initially identified many different kinds of knowledge, art, and practices, both traditional and modern, that they would like to see recognised and protected.

Knowledge. Knowledge may be group or individual, secret or nonsecret, and sacred or non-sacred. It includes

- oral knowledge, such as that passed on through song, stories, legends and poems

- visual arts and design

- warfare, fighting, physical performance (dance and sport)

- sexual practices and gender roles

- music

- navigation, knowledge of place, geographical knowledge, ecological knowledge

- technical knowledge, such as gardening, medicine, fishing, weaving, dyes, weapons, clothing manufacture

- spiritual knowledge, knowledge of sacred sites

- language

- genealogy and kinship relationships

- leadership, discipline systems, respect systems, authority, political systems.

Arts. Identified arts that should be recognised and protected include

- music

- carving, crafts, painting and other artistic practices

- drama 
- design

- textiles, weaving, etc.

- architecture and other physical structures

- landscape gardening

- body ornamentation.

Practices. Traditional practices include knowledge and art and exist through recognition, protection, reproduction, and continued practice. They include

- education models and systems

- value systems

- religious systems.

\section{Recommendations}

In the process of developing recommendations, the group noted that it is fundamental to recognise and give value to knowledge, art and practices in order to ensure their protection and reproduction. Some mechanisms for recognition will also serve to preserve intellectual property. Recognition mechanisms

- Awareness programs should be implemented at all levels-national, sub-national, village, community, clan, family - to stress the importance and value of knowledge, art, and practices as a foundation for sustainable development. Awareness programs have the potential to reaffirm traditions and reverse the Euro-American bias of modern education.

- Campaigns, slogans, educational programs and local meetings could promote recognition that non-secret and secret knowledge is important, and that the secrecy should be respected.

- National and local shows, festivals, and competitions (such as singsings, canoe races, school competitions, agricultural shows) could help achieve recognition and support for traditional knowledge, art and practices.

- The publication and distribution of traditional intellectual property could help preserve it by promoting its value and use.

- The use or employment of local experts and authorities as resource persons and/or through formal and informal educational systems can keep traditional knowledge, art and practices alive and in the public eye. Similarly, the designation of individuals who possess traditional knowledge as 'living treasures' can help promote its sustainability. 


\section{Protection mechanisms}

- Changing and promoting educational priorities to train people at all levels, particularly at the local level, in fields relevant to the protection of intellectual property (including art, linguistics, performing arts, anthropology/archeology, biology/systematics, architecture, pharmacology, chemistry) is key.

- Recording and creating inventories of intellectual property (though writing, photography, video, song, etc.) so that it is available to the original creators or informants of the information and to repositories for national, provincial and local use.

- The development of appropriate and enforceable legislation at national, provincial and local levels (including copyright, memoranda of understanding for researchers, a permit system, customary laws) are necessary.

- The promotion of research into traditional systems of education and learning and then incorporating those methods into formal and informal educational systems, where appropriate, can help to keep culture alive and prevent it from being swallowed by more dominant cultures.

- Similarly, linguistic research is important to keep local languages alive. Compilations of local languages can serve to record biological and cultural knowledge which is endangered, such as traditional ceremonies, foods, artwork, and the medicinal uses of plants.

- Development of an integrated media strategy can help to enhance the protection and recognition of intellectual property and minimise the trivialisation and loss of biological and cultural knowledge. Moreover, the media should play a role in preventing the dissemination of inappropriate messages. A helpful strategy might be to revitalise provincial television stations and local television content.

- Sacred sites should be registered and the individuals or land-groups associated with them certified as their custodians.

- Cultural and biological knowledge and institutions that are considered 'endangered' should also be registered.

- The efforts of religious bodies to respect and incorporate traditional beliefs into spiritual development should be supported.

- Traditional environmental and cultural management strategies should be incorporated into all sectors of national planning and development-environment, tourism, fisheries, agriculture, health, education, mining, justice-as an integral component. 
- An interagency national task force consisting of representative membership from agencies responsible for recognising and protecting intellectual property, such as the National Cultural Commission, the National Museum, the University of Papua New Guinea, and nongovernmental organisations, should be established to promote and coordinate recognition and protection of intellectual property in Papua New Guinea. Provincial level task forces might also be created to interface with communities and individuals to respond to requests and problems related to intellectual, biological and cultural property rights.

- Community or landowner-based biological and/or cultural protection action plans should be developed based on identification by local communities of what should be protected and recognised due to its value and threatened status.

\section{Questions}

The economic consequences of establishing intellectual property rights infrastructure would be significant. The immediate training of Papua New Guineans in the legal issues involved and in how to operate within the legal system is vital. Similarly, the nomination of Papua New Guineans for training abroad in other important areas is important.

High levels of training are not necessary to establish or operate awareness programs, nor are people from outside; it is important to inspire the process from within.

Databases are great for the future, but we must start the collection process at the local level now. Biological inventories are also important, but the strategy should be to add value to the resources as they are inventoried. The intellectual property rights system does not provide benefits until you are at the cutting edge of technology. We are only at the beginning of the process. Thus, we need to figure out how to add value to our resources before we reach that point. We need to train people in the law and the legal issues behind intellectual property, and in community mediation; we need lawyers who are educated rather than trained.

As far as biological property goes, we need time to consider all the information that we have and will receive in the future. We do not know yet what is missing in our knowledge and need time to figure it out. It is important to protect it so we have time. 


\section{Group members}

Randy Thaman, University of the South Pacific

Marianna Ellingson, National Planning Office

Reddy Kuama, Pacific Adventist University

Steven Thomas, Bible Translation Association

Heino Hertel, Christensen Research Institute

Hazel Blowers, Architectural Heritage Center

Claudia Gross, Papua New Guinea National Museum

Reverend Oria Gemo, Office of Information and Communication

\section{Discussion group 4: Andrew Moutu presenter}

How can Papua New Guinea achieve international recognition for intellectual, biological and cultural property that builds upon the traditional practices of its indigenous communities?

International structures currently in existence do not necessarily reflect the reality of people we are talking about. The concept of tradition portrays an exotic idea of Papua New Guinea; we are dynamic. Papua New Guinea ways are better.

Biological property. There must be prior informed consent and discussion of the risks and benefits.

Biogenetic resources. A human subjects committee should be trained in place to address all the issues. Papua New Guineans should be in research and genetics. Research policy in Papua New Guinea should be reviewed so there is provision for reciprocity of knowledge and other things.

Contracts/control. These should be designed to ensure that people are not exploited.

Cultural property. Conventions recognise diversity and conception of cultural heritage. The place of customary law in relation to questions like property, ownership, price, rights (what are the conceptions?) should be re-examined. There is concern that within an intellectual property rights framework, Papua New Guinea ideas of property will not be seen as something that can be bought and sold. The concept of knowledge ownership may be transformed

National cultural policy instituted by National Cultural Commission. Papua New Guinean ways of doing things must be recognised. There is also a need to provide a running definition of the notion of culture. 
Copyrights. Legislation should be reviewed with reference to indigenous knowledge to see if it is relevant. Must copyright have a registry? Does it matter who gets there first? How can we protect people?

International recognition. The capacity of any country is limited by its national jurisdiction. It is therefore important to bring the issue of prior informed consent into the international debate. Obligations should be imposed on companies. They must show prior informed consent when submitting products. We need a sui generis regime at the national level and a multi-national way to make use of and oversee national regimes.

Prior informed consent can be achieved over time given a regular dialogue. We cannot require everyone to have a doctorate in genetics, but we can translate these concepts into Tok Pisin and the use of technical language is inappropriate. However this takes time and effort and it is a process.

Human subjects report. An independent person or body should have the responsibility to determine whether prior informed consent has actually occurred.

\section{Group members}

Andrew Moutu, PNG National Museum and Art Gallery

Sam Yakam, Department of Commerce

Chris Isaac, National Cultural Commission

Theo Yasause, Department of Foreign Affairs and Trade

Dr John Muke, University of Papua New Guinea

Dr Mark Busse, PNG National Museum and Art Gallery

\section{Discussion group 5: Mike Parsons, Anthony Parak presenters}

How can Papua New Guinea effectively include provisions for prior informed consent, benefit-sharing and local community control in policies or legislation regulating natural product development?

\section{Recommendations}

\section{Prior informed consent}

- The state should assume responsibility for ensuring that researchers and developers have full prior informed consent. This might involve establishment of a body or identification of certain people who are responsible for ascertaining whether or not consent has been 
adequately sought and approved. It might also involve a certification process. All parties to a natural product development project must be aware of all issues regarding prior informed consent at all stages of the project: the agreement, the project nature, the value of the project, the advantages and disadvantages of the project.

- The people from whom consent is sought should have adequate access to appropriate advisors in financial, legal and technical matters relating to the project. This presupposes an educative process to make people aware of what their rights are and to help them value their resources in light of outside needs and uses.

- It is important not to raise people's expectations.

Benefit-sharing

- Communities or representative individuals must regulate the distribution of benefits according to negotiated and accepted terms of agreement.

- The government should provide a framework or guidelines (in the form of policy or legislation) for benefit-sharing, and provide support to ensure that it is carried out properly. This does not mean that the government should be interfering or micromanaging the process, but that a broad policy framework should be developed to enable people to retain rights in what they sell. Examples of such frameworks exist in other places in the world.

\section{Local community control}

- Local community control should be changed to local community participation. Local community participation should be promoted by providing technical and financial assistance in setting up natural product development ventures, such as teaching local people to screen and isolate chemicals derived from plants in Papua New Guinea.

- A national body and facility should be set up to screen and isolate useful properties of local genetic and biochemical materials. Crude screening of all raw materials should take place in-country and should involve the participation of local people.

- The participation of local people should take into account customary laws, taboos, or other restrictions. There should be an administrative body to regulate natural product development policies and to promote natural products research and development. Regulation. should cover

- access to natural products, including prior informed consent, access rights and agreements 
- the collection of specimens, information, data

- the processing and development of natural products

- the promotion of local development and incentives.

- In addition, all existing legislation covering these topics should be reviewed and, if necessary, amended to make them more effective. The group does not believe that patents or other commercial intellectual property laws should be implemented at this time.

\section{Group members}

Mike Parsons, UNDP

Anthony Parak, Papua New Guinea National Museum

Meg Taylor, Conservation Melanesia

Silina Tagagau, Conservation Melanesia

William Staley, Summer Institute of Linguistics

Minnie Bate, Gemins Herbal Products

Brendan Tobin, Peruvian Society for Environmental Law

\section{Discussion group 6: Mike Hedemark presenter}

How can Papua New Guinea develop a national-level strategy to inventory its biodiversity and integrate all collections into one physical and administrative entity?

The group felt strongly about two initial points. First, if Papua New Guinea is going to develop laws to protect the components of biodiversity it must first conduct an inventory of its biodiversity. It is important to know what's out there and what needs to be protected. Second, it is not a good idea to integrate all biodiversity collections into one physical and administrative entity.

The group then identified a number of concerns related to biodiversity data management.

- The availability of currently existing information in both the public and private domain is problematic. We are looking at ways of managing biodiversity so the first step should be to develop an information base.

- A biodiversity data management program is the first step to developing an integrated information base. Such a management program should address issues related to access and sharing of data (territoriality), policy and domicile questions (who will the coordinating agency be) and recovery of costs. 
- Government recognition and support for a revised biodiversity management committee is needed. The committee is not getting appropriate recognition now.

- The process for granting and validating research permits should be reassessed. A code of conduct for individuals engaging in socioeconomic and scientific ventures in the field should be developed.

- The biodiversity strategy framework document and process needs to be revitalised; it exists but has never been implemented.

- National collections (the National Museum, herbaria, gardens, research stations) are a neglected national resource and should receive funding to at least prevent further deterioration.

- National capacity-building in implementation of intellectual property rights management regimes and biodiversity potentials is needed.

- Intellectual and biological property rights policy and regulations concerning biological products should be promoted.

- The need to implement the Science and Technology Council legislation and policy.

\section{Recommendations}

\section{Resources}

Long-term. The considered view of the biodiversity data management committee is that the development of a national-level inventory of biodiversity and its integration into one physical and administrative entity if feasible but only in the long-term. The biodiversity data management committee should examine strategies for working towards a national inventory and biodiversity inventory. This should include recognition of what information is already available and what needs to be inventoried and protected in the future.

Short-term. The development of a biodiversity strategy and process for furthering biodiversity data management should include, inter alia

- a process for integrating data

- the development of protocols for integrity, access, use, and levels of access to biodiversity data

- maintenance of current custodial responsibilities for data bases; each organisation is appropriate for the data they hold, but they need to be resourced better to make them better custodians.

- consideration of copyright issues in relation to databases

- increased support for non government organisations, universities, and other groups involved with database development 
Another short-term strategy should be to develop a 'natural collections policy' for the support and maintenance of national collections.

\section{Regulation and administration}

Long-term. Papua New Guinea should develop a strategy and legislation on access (freedom) of information in a distributive network of biodiversity databases.

\section{Short-term}

- An urgent review of the socioeconomic and scientific research permit process is needed, as well as the development of a code of conduct for researchers and developers. There is currently no central depository or list of people who have worked in Papua New Guinea.

- Papua New Guinea should establish a national committee for the regulation of access to the country's biological materials and its corresponding information. The national committee should have a mandate to draft policy and procedures for consideration and endorsement by government. Legal and community representation will be required in this process.

- The development of an intellectual and biological property rights policy and strategy needs to consider the associated costs, benefits, and losses.

- The government should establish the Science and Technology Council and implement approved policy initiatives.

- Formal recognition and support for a revised biodiversity management committee needs to be provided.

- The work on the biodiversity strategy framework process need to be revitalised.

\section{Training needs}

Long-term. There is a need to develop a national capacity-building process at all levels in the implementation of intellectual property rights regulations by universities, relevant institutions and non government organisations both in-country and overseas.

Short-term. A register of science researchers should be established immediately. 


\section{Group members}

Lance Hill, Biology, University of Papua New Guinea Mike Hedemark, UNDP

Jacqueline Boga, Papua New Guinea Forest Authority Konet Sapulai, National Statistical Office Chuck Burg, Conservation International Osia Gideon, Forestry Research Institute Hane Tabe, Department of Attorney General Nina Puddicombe, Australian High Commission Rick Bein, Papua New Guinea University of Technology Nancy Ebbes, National Planning Office Ilaiah Bigilalie, Papua New Guinea National Museum John Aruga, Department of Environment and Conservation Esthel Gombo, University of Papua New Guinea Ruby Yamuna, University of Papua New Guinea 


\section{References}

Abbott, Frederick M., 1997. 'Treaty regimes', in A. D'Amato and D.E. Long (eds), International Intellectual Property Law, Kluwer Law International, London:13-4.

Allen, J., 1970. 'Prehistoric agricultural systems in the Wahgi Valley: a further note', Mankind, 7(3):177-83.

Alpers, M. and Gajdusek, D.C., 1965. 'Changing patterns of kuru: epidemiological changes in the period of increasing contact of the Fore people with western civilization', American Journal of Tropical Medicine and Hygiene, 14:852-79.

Axt, J., Corn, M., Lee, M. and Ackerman, D., 1993. Biotechnology, Indigenous Peoples, and Intellectual Property Rights, Congressional Research Service Report for Congress, Washington DC.

Barth, Fredrik, 1975. Ritual and Knowledge among the Baktaman of New Guinea, Yale University Press, New Haven.

Bartholomew, S., 1997. National Systems of Biotechnology Innovation: complex interdependence in the global system, Research Institute of Management Studies, Judge Institute of Management Studies, University of Cambridge, Cambridge.

Baxter, J.W. and Sinnott, J.P., 1992. World Patent Law and Practice, Matthew Bender, New York.

Beehler, B.M., 1992. Background data on Papua New Guinea, Paper presented at the workshop on Preparation of conservation needs for

Papua New Guinea, Madang (unpublished).

Bozecevic, K., 1987. 'Distinguishing products of nature', Journal of the Patent and Trade-mark Office Society, August:415-26. 
Brown, P., 1978. 'New Guinea: ecology, society, and culture', Annual Review of Anthropology, 7:263-91.

Brush, S.B., 1993. 'Indigenous knowledge of biological resources and intellectual property rights: the role of anthropology', American Anthropologist, 9(3):653-86.

- 1994. Providing farmers' rights through in-situ conservation of crop genetic resources, Commission of Plant Genetic Resources, First Extraordinary Session, Paper Number 3, Food and Agriculture Organisation, Rome.

— - and Stabinsky, D., 1996. Valuing Local Knowledge: indigenous peoples and intellectual property rights, Island Press, Washington DC.

Burger, Peter, 1997. 'The Berne Convention: an historical overview', in A. D'Amato and D.E. Long (eds), International Intellectual Property Law, Kluwer Law International, London:260-4.

Capson, T., forthcoming. Ethnobotanical studies in Papua New Guinea: new strategies for the discovery of medicines from rainforest plants and the creation of opportunities for sustainable economic development.

Carrier, James, 1996. 'Exchange', in A. Barnard and J. Spencer (eds), Encyclopedia of Social and Cultural Anthropology, Routledge, London:218-21.

- 1998. 'Property and social relations in Melanesia', in C.M. Hann (ed.), Property Relations: renewing the anthropological tradition, Cambridge University Press, Cambridge:85-103.

Connolly, B. and Anderson, R., 1987. First Contact: New Guinea Highlanders encounter the outside world, Viking Penguin, New York.

Correa, C.M., 1994. Sovereign and Property Rights Over Plant Genetic Resources, Commission on Plant Genetic Resources, First Extraordinary Session, Paper Number 2, Food and Agriculture Organisation, Rome.

Cox, P.A. and Balick, M.J., 1994. 'The ethnobotanical approach to drug discovery', Scientific American, June:84-7.

Crucible Group, 1994. People, Plants and Patents, International Development Research Centre, Ottowa. Available from Internet: <URL:http://www.irdc.ca/books> 
D'Amato, A. and Long, D.E, 1997. 'The role of Berne in the twentyfist century', in A. D'Amato and D.E. Long (eds), International Intellectual Property Law, Kluwer Law International, London:267-8.

Dembo, D., Dias, C. and Morehouse, W., 1985. 'Biotechnology and the Third World: some social, economic, political and legal impacts and concerns', Rutgers Computer \& Technology Law Journal, 11:431, $441,450-2$.

Demiray, A. David, 1997. 'TRIPS: the effort at harmonization', in A. D'Amato and D.E. Long (eds), International Intellectual Property Law, Kluwer Law International, London:268-9.

Doolittle, R.F., Feng, D.F., Johnson, M.S. and McClure, M.A., 1989. 'Origins and evolutionary relationships of retroviruses', Quarterly Review of Biology, 64:1-30.

Douglas, N., 1996. They Came for Savages: 100 years of tourism in Melanesia, Southern Cross University Press, Armidale.

Drahos, Peter, 1996. A Philosophy of Intellectual Property Law, Aldershot, Dartmouth.

Dwyer, Peter, 1994. 'Modem conservation and indigenous peoples: in search of wisdom', Pacific Conservation Biology, 1:91-7.

Epstein, A.L., 1969. Matupit: land politics and change among the Tolai of East New Britain, The Australian National University Press, Canberra.

- 1992 . In the Midst of Life: affect and ideation in the world of the Tolai, University of California Press, Berkely, Los Angeles and Oxford.

Errington, F.M., 1974. Karavara: masks and power in a Melanesian ritual, Cornell University Press, Ithaca.

Fagan, B., 1980. People of the Earth: an introduction to world prehistory, Little Brown and Company, Boston.

- 1990. The Journey from Eden: the peopling of our world, Thames and Hudson, New York.

Feil, D., 1987. The Evolution of Highland Papua New Guinea Societies, Cambridge University Press, Cambridge.

Feld, Steven, 2000. 'A sweet lullaby for world music', Public Culture, $12(1): 145-71$.

Filer, C., 1997. 'Compensation, rent and power in Papua New Guinea', in S. Toft (ed.), Compensation for Resource Development in Papua New Guinea, Law Reform Commission of Papua New Guinea Monograph 
No 6, Resource Management in Asia and the Pacific (Research School of Pacific and Asian Studies, The Australian National University), National Centre for Development Studies Pacific Policy Paper 24 (The Australian National University), Canberra:156-89.

Food and Agriculture Organisation, 1993. International Undertaking on Plant Genetic Resources, Commission on Plant Genetic Resources, Fifth Session, Food and Agriculture Organisation, Rome.

Fourmile, H., 1998. 'Using prior informed consent procedures under the convention on biological diversity to protect indigenous traditional ecological knowledge and natural resource rights', Aboriginal Law Bulletin, 4(16):14-17.

Gervais, Daniel, 1998. The TRIPS Agreement: drafting history and analysis, Sweet and Maxwell, London.

Ginsburg, Jane C., 1997. 'The harmonizing role of historical accuracy', in A. D'Amato and D.E. Long (eds), International Intellectual Property Law, Kluwer Law International, London:79-80.

Goldman, K., 1994. 'Compensation for the use of biological resources under the Convention on Biological Diversity: compatability of conservation measures and competitiveness of the biotechnology industry', Law and Policy in International Business, 25:695-726.

Gollin, M. 1993. 'An intellectual property rights framework for biodiversity prospecting', in W.V. Reid, S.A. Laird, C.A. Meyer, R. Gamez, A. Sittenfield, D.H. Jansen, M.A. Gollin and C. Juma (eds), Biodiversity Prospecting, World Resources Institute, Washington DC:159-97. and Laird S.A., 1996. 'Global policies, local actions: the role of national legislation in sustainable biodiversity prospecting', Boston University Journal of Science and Technology Law, 2(16):1-104.

Golson, J., 1977. 'No room at the top: agricultural intensification in the New Guinea Highlands', in J. Allen, J. Golson and R. Jones (eds), Sunda and Sabul: prehistoric studies in Southeast Asia, Melanesia and Australia, Academic Press, London:601-38.

, 1982. 'Agriculture in New Guinea: the long view', in D. Denoon and C. Snowden (eds), A Time to Plant and a Time to Uproot: a history of agriculture in Papua New Guinea, Institute of Papua New Guinea Studies, Port Moresby:33-42. 
-, Lampert, R.J., Wheeler, J.M., and Ambrose, W.R., 1967. 'A note on carbon dates for horticulture in the New Guinea Highlands', Journal of the Polynesian Society, 76:369-71.

and Swadling, P., 1998. 'The nomination of Kuk for inclusion in the World Heritage listing', in A. Strathern and P.J. Stewart (eds), Kuk Heritage: issues and debates in Papua New Guinea, Papua New Guinea National Musuem with Centre for Pacific Studies (James Cook University) and Department of Anthropology, Port Moresby and Pittsburgh:1-18.

Greaves, T., (ed.), 1994. Intellectual Property Rights for Indigenous Peoples: a sourcebook, Society for Applied Anthropology, Oklahoma City.

Gregory, C., 1982. Gifts and Commodities, Academic Press, London.

Glowka, L., 1998. A Guide to Designing Legal Frameworks to Determine Access to Genetic Resources, IUCN Environmental Law Centre, Gland.

Groube, L.M., Chappell, J., Muke, J. and Price, D., 1986. 'A 40,000 year-old human occupation site at Huon Peninsula, Papua New Guinea', Nature, 324:435-55.

Hann C., (ed.), 1997. Property Relations: sharing, exclusion, legitimacy, Cambridge University Press, Cambridge.

- 1998. 'Introduction: the embeddedness of property', in C. Hann (ed.), Property Relations: renewing the anthropological tradition, Cambridge University Press, Cambridge: $1-47$.

Harding, T., 1972. 'Land tenure', in P. Ryan (ed.), Encyclopaedia of Papua and New Guinea, Melbourne University Press and University of Papua and New Guinea, Melbourne, book two:604-10.

Harrison, S., 1992. 'Ritual as intellectual property', Man, 27:225-43.

- 1995. 'Anthropological perspectives on the management of knowledge', Anthropology Today, 11(5):10-14.

Hill, L., 1985. 'Preliminary bibliography on the traditional medicinal plants of Papua New Guinea', in W. Jilek (ed.), Traditional Medicine and Primary Health Care in Papua New Guinea, University of Papua New Guinea Press, Port Moresby:135-61.

Holdsworth, D.K., 1977. Medicinal Plants of Papua New Guinea, Technical Paper Number 175, South Pacific Commission, Noumea. 
Huft, M.J., 1995. 'Indigenous peoples and drug discovery research: a question of intellectual property rights', Northwest University Law Review, 89(4):1678-730.

Kambuou, R.N., 1995. The current status and prospects of plant genetic resources in Papua New Guinea, Paper prepared for Agricultural Research Division, Department of Agriculture and Livestock, Konedobu (unpublished).

Kasaipwalova, J., 1975. Sopi: the adoption of a traditional aesthetic concept for the creation of a Modern Art School on Kiriwina, Discussion Paper Number 5, Institute of Papua New Guinea Studies, Port Moresby.

Katz, R.A. and Skalka, A.M., 1990. 'Generation of diversity in retroviruses', Annual Review of Genetics, 24:409-45.

Laird, S., 1993. 'Contracts for biodiversity prospecting', in W.V. Reid, S.A. Laird, C.A. Meyer, R. Gamez, A. Sittenfield, D.H. Jansen, M.A. Gollin and C. Juma (eds), Biodiversity Prospecting, World Resources Institute, Washington DC:99-130.

Laird, S.A., 1995. Access Controls for Genetic Resources: the assertion of sovereignty, World Wildlife Fund, Washington DC.

Lange, David, 1997. 'The suppressive role of historical copyright', in A. D'Amato and D.E. Long (eds), International Intellectual Property Law, Kluwer Law International, London:76-9.

Lesser, W.H., n.d. Institutional mechanisms supporting trade in genetic materials: issues under the biodiversity convention and GATT/ TRIPs, Environment and Trade series, United Nations Environment Program.

Ley, J.F., 1991. Australia's Protection of Movable Cultural Heritage, Report on the Ministerial Review of the Protection of Movable Cultural Heritage Act 1986 and Regulations, Australian Government Publishing Service, Canberra.

Liberski, P.P., Jenkins, C.J., Sanders, R.C., and Alpers, M.P., 1990. 'Isolation of HTLV-I from members of a remote tribe in New Guinea', New England Journal of Medicine, 323:993-4.

Linden, Eugene, 1991. 'Lost tribes, lost knowledge', Time, 138(12): $46-55$. 
Long, D.E., 1997. 'GATT v. WIPO: the jurisdictional dilemma', in A.

D'Amato and D.E. Long (eds), International Intellectual Property Law, Kluwer Law International, London:242-3.

and D'Amato, A., 1997. 'Overview', in A. D'Amato and D.E. Long (eds), International Intellectual Property Law, Kluwer Law International, London:1-10.

Macfarlane, Alan, 1998. 'The mystery of property', in C.M. Hann (ed.), Property Relations: renewing the anthropological tradition, Cambridge University Press, Cambridge.

Macpherson, C.B., 1978. 'The meaning of property', in C.M. Hann

(ed.), Property Relations: renewing the anthropological tradition,

Cambridge University Press, Cambridge:1-13.

Malinowski, Bronislaw, 1922. Argonauts of the Western Pacific, Dutton, New York.

Margulies, R., 1992. 'Protecting biodiversity: recognising international intellectual property rights in plant genetic resources', Michigan Journal of International Law, 14:322-56.

Mauss, Marcel, 1925. 'Essai sur le Don, Forme et raison de l'echange dans les sociétés archaïques', Année sociologique, 1(n.s.):30-186.

- 1967. The Gift: forms and functions of exchange in archaic societies, (trans. Ian Cunnison), W.W. Norton and Company, New York.

Mills, Sherylle, 1996. 'Indigenous music and the law: an analysis of national and international legislation', Yearbook for Traditional Music, 28:57-86.

Morauta, L., 1979. 'Indigenous anthropology in Papua New Guinea', Current Anthropology, 20(3):561-76.

Moufang, R., 1994. 'Patenting of human genes, cells and parts of the body? - the ethical dimensions of patent law', International Review of Industrial Property and Copyright Law, 25:487-515.

Moutu, A., 1998. 'The Kuk research station and the Kawelkas', in A. Strathern and P.J. Stewart (eds), Kuk Heritage: issues and debates in Papua New Guinea, Papua New Guinea National Musuem with Centre for Pacific Studies (James Cook University) and Department of Anthropology, Port Moresby and Pittsburgh:20-41.

Moy, R. Carl, 1997. 'The Paris Convention: an historical overview', in A. D'Amato and D.E. Long (eds), International Intellectual Property Law, Kluwer Law International, London:247-53. 
Muke, J., 1992. The Wahgi Opo Kumbo: an account of warfare in the Central Highlands of New Guinea, Ph.D Thesis, University of Cambridge, Cambridge.

—, 1998. 'The death (and re-birth) of Kuk: a progress report on the recent developments at the Kuk prehistoric site', in A. Strathern and P.J. Stewart (eds), Kuk Heritage: issues and debates in Papua New Guinea, Papua New Guinea National Musuem with Centre for Pacific Studies (James Cook University) and Department of Anthropology, Port Moresby and Pittsburgh:64-86.

—, n.d. A 2000 year old curcubit plant from the Kana site, Minj, Western Highlands, Papua New Guinea (unpublished).

Nairn, C., Stathern, A. and Ongka, 1983. Kawelka: Ongka's big moka [videorecording], Granada, London.

Narokobi, B., 1980. The Melanesian Way, Institute of Papua New Guinea Studies, Boroko.

Neumann, Klaus, 1992. Not the Way it Really Was: constructing the Tolai past, University of Hawaii Press, Honolulu.

Nijar, Gurdial Singh, 1995. In Defence of Indigenous Knowledge and Biodiversity, Third World Network, Penang.

Niles, Don, 1992. 'Traditional and contemporary concerns relating to copyright in Papua New Guinea', Phonographic Bulletin, 61:55-62.

- 1996. 'Questions of music copyright in Papua New Guinea', Perfect Beat, 2(4):58-62.

Nonggorr, John, 1990. 'The introduction of copyright law in Papua New Guinea', Melanesian Law Journal, 18:1-17.

- 1995. "The development of an "indigenous jurisprudence" in Papua New Guinea: the past record and future prospects', in J. Aleck and J. Rannells (eds), Custom at the Crossroads, Faculty of Law, University of Papua New Guinea, Port Moresby:68-83.

Nowak, R., 1995. 'Patent award stirs a controversy', Science, 267:899.

O'Hanlon, M. and Frankland, L., 1986. 'With a skull in the netbag: prescriptive marriage and matrilateral relations in the New Guinea Highlands', Oceania, 56(2):181-98.

Ongka, 1979. Ongka: a self-account by a New Guinea big-man, (trans. A. Strathern), Duckworth, London. 
Ottley, B.L., 1995. 'Looking back to the future: the colonial origins of current attitudes toward customary law', in J. Aleck and J. Rannells (eds), Custom at the Crossroads, Faculty of Law, University of Papua New Guinea, Port Moresby:97-107.

Parry, B., 1997. 'Whose booty is it anyway?', New Scientist, 154(2087):50. Posey, D., 1994. 'International agreements and intellectual property right protection for indigenous peoples', in T. Greaves (ed.), Intellectual Property Rights for Indigenous Peoples: a source book, Society for Applied Anthropology, Oaklahoma City:223-40.

- 1996a. Provisions and Mechanisms of the Convention on Biological Diversity for Access to Traditional Technologies and Benefit Sharing for Indigenous and Local Communities Embodying Traditional Lifestyles, Research Paper, OCEES, Oxford.

— 1996b. Traditional Resource Rights: international instruments for protection and compensation for indigenous peoples and local communities, Gland, Switzerland, and International Union for the Conservation of Nature, Cambridge.

- and Dutfield, G., 1996. Beyond Intellectual Property: toward traditional resource rights for indigenous peoples and local communities, International Development Research Centre, Ottawa.

Power, P.A., 1992. 'Interaction between biotechnology and the patent system', Australian Intellectual Property Journal, 3:214-31.

Reid, B. and La Vina, A., 1995. Translating Genetic Resource Rights into Sustainable Development, OBF, Jakarta.

Reid, W.V., Laird, S.A., Meyer, C.A., Gamez, R., Sittenfield, A., Jansen, D.H., Gollin, M.A. and Juma, C. (eds), 1993 a. Biodiversity Prospecting, World Resources Institute, Washington DC.

—, 1993b. 'A new lease on life', in W.V. Reid, S.A. Laird, C.A. Meyer, R. Gamez, A. Sittenfield, D.H. Jansen, M.A. Gollin and C. Juma (eds), Biodiversity Prospecting, World Resources Institute, Washington DC: $1-52$.

Renfrew, C. and Bahn, P., 1991. Archaeology: theories, methods and practice, Thames and Hudson, London. 
Rivera, V.S. and Cordero, P.M., 1999. Costa Rica's biodiversity law: sharing the process, Paper presented at the Workshop on Biodiversity Conservation and Intellectual Property Regimes, New Delhi, 29-31 January (unpublished).

Robertson, J.A., 1994. Children of Choice: freedom and the new reproductive technologies, Princeton University Press, Princeton.

Said, E., 1991. Orientalism: western conceptions of the orient, Penguin Books, England.

Salisbury, R.F., 1970. Vunamami: economic transformation in a traditional society, University of California Press, Berkely and Los Angeles.

Schwartz, Theodore, 1975. 'Cultural totemism: ethnic identity, primitive and modern', in G. DeVos and L. Romanucci-Ross (eds), Ethnic Identity, Mayfield, Palo Alto:106-31.

Sherman, B., and Bently, L., 1999. The Making of Modern Intellectual Property Law: the British experience, 1760-1911, Cambridge University Press, Cambridge.

Shiva, V., 1992. 'The seed and the earth: biotechnology and the colonisation of regeneration', Development Dialogue, 1(2):151-68.

Shiva, V., 1995. Captive Minds, Captive Lives: essays on ethical, ecological implications on patents on life, Research Foundation for Scientific, Technology and Natural Resources Policy, Dehra Dun, India.

Sillitoe, P., 1988. 'Property ownership in the New Guinea Highlands', Research in Melanesia, 10:1-11.

Simpson, T., 1997. Indigenous Heritage and Self-determination: the cultural and intellectual property rights of indigenous peoples, IWGIA Document No 86, Copenhagen.

Strathern, A., 1984. A Line of Power, Tavistock, London.

- 1985. 'Research in Papua New Guinea: cross-currents of conflict', in R. Grillo and A. Rew (eds), Social Anthropology and Development Policy, Tavistock Publications, London:168-84.

and Stewart P.J., (eds), 1998. Kuk Heritage: issues and debates in Papua New Guinea, National Museum, Port Moresby, with Centre for Pacific Studies, James Cook University, and Department of Anthropology, University of Pittsburgh. 
Strathern, M., 1996. 'Potential property: intellectual rights and property in persons', Social Anthropology, 4(2):17-32.

Strong, S. L., 1997. 'Copyright under international copyright conventions', in A. D'Amato and D.E. Long (eds), International Intellectual Property Law, Kluwer Law International, London.

Swanson, T., 1995. 'Intellectual property rights and biodiversity conservation' (book review), IPGRI/FAO Plant Genetic Resources Newsletter, 106.

Swartzendruber, J.F., 1993. Papua New Guinea Conservation Needs Assessment: synopsis report, World Wildlife Fund, Nature Conservation, World Resources Institute, Department of Environment and Conservation (Papua New Guinea), Boroko.

Talyaga, K.K., 1974. Should we Allow Research Workers and Tourists into the Enga Area?, Discussion Paper No 1, Institute of Papua New Guinea Studies, Port Moresby.

Tobin, B., 1997a. 'Certificates of origin: a role for intellectual property rights regimes in securing prior informed consent', in J. Mugabe, C.V. Barber, G. Henne, L. Glowka and A. La Vina (eds), Access to Genetic Resources: stategies for sharing benefits, ACTS Press and IUCN, Nairobi:329-40.

- 1997b. Putting the commercial cart before the cultural horse: a study of the ICBG Project in Peru, (unpublished).

Thomas, N., 1991. Entangled Objects: exchange, material culture, and colonialism in the Pacific, Harvard University Press, Cambridge.

UNESCO, 1999. Symposium on the Protection of Traditional Knowledge and Expressions of Indigenous Cultures in the Pacific Islands, Secretariat of the Pacific Community, Noumea.

Wesche, D.L., 1987. 'The incorporation and development of traditional medicine with western scientific medicine: some ethical considerations', in S. Stratigos and P.J. Hughes (eds), The Ethics of Development: justice and the distribution of health care, University of Papua New Guinea Press, Port Moresby:71-8.

Whitehead, H., 1986. 'The varieties of fertility cultism in New Guinea', American Ethnologist, 13:80-99, 271-89. 
Whimp, K., 1997a. 'Intellectual property issues in biodiversity data management in Papua New Guinea', in Proceedings of the Intellectual, Biological and Cultural Property Rights Seminar, 13-15 August 1997, Port Moresby.

- $1997 \mathrm{~b}$. Intellectual property issues in use of biological resources and biodiversity data management in Papua New Guinea, Report to the Papua New Guinea Biodiversity Data Management Project (unpublished).

Williams, F.E., 1923. The Collection of Curios and the Preservation of Native Culture, Anthropology Report Number 3, Government Printer, Port Moresby.

Yamin, F. and Posey, D., 1993. 'Indigenous people, biotechnology and intellectual property rights: review of European Community and International Environmental Law', Indigenous Peoples, 2(2):141-8.

Yanagihara, R., Garruto, R.M., Miller, M.A., Leon-Monzon, M., Liberski, P.P., Jenkins, C.J., Sanders, R.C., and Alpers, M.P., 1990. 'Isolation of HTLV-I from members of a remote tribe in New Guinea', New England Journal of Medicene, 323:993-4.

Yanagihara, R., Nerurkar, V.R. and Ajdukiewicz, A.B., 1991.

'Comparison between strains of human $\mathrm{T}$ lymphotropic virus type I isolated from inhabitants of Solomon Islands and Papua New Guinea', Journal of Infectious Diseases, 164:443-9.

Zemp, Hugo, 1996. 'The/an ethnomusicologist and the record business', Yearbook for Traditional Music, 28:36-56.

Zigas, V. and Gajdusek, D.C., 1957. 'Kuru: clinical study of a new syndrome resembling paralysis agitans in natives of the Eastern Highlands of Australian New Guinea, Medical Journal of Australia, $2: 745-54$. 


\section{Recordings referred to in text}

Black Brothers, 1983. 'Jalikoe' by Papua (track A3), Disco Festival 83, King's K 521 ED, Cassette.

Clarke, William C., 1995. Faces of Papua New Guinea, Wayzata 3211, CD-ROM.

Deep Forest, 1992. 'Sweet Lullaby' (track 2), Deep Forest, Celine Musicl Sony Music DAN 4719762, CB 791, Compact disc.

Drum Drum, 1996. Lahi Gabua; Light the Fire, PMI, Compact disc. Gaba Kaluks, 1985. 'Vero' (track B4), Gaba Kaluks, NBC B 226, Cassette.

Miracle G(y)rlz, 1997?. 'Listen moho' (track 3), Candy's Hardware Bazaar, TUG 066, Compact disc.

—, n.d. Available from Internet:<URL:http://avus.de/viktoria/bands/ miracle_gyrlz/index.htm>

Not Drowning, Waving, 1986. The Sing Sing, Rampant Releases MLRR005, Disc.

$\longrightarrow$ 1987. Cold and the Crackle. Rampant Releases RR040, Disc.

- 1990 a. Not Drowning Waving Recorded in PNG/Australia, Pacific Gold PAC-381, Cassette.

- with Telek, George. 1990b. Tabaran; Not Drowning, Waving and the Musicians of Rabaul, Papua New Guinea featuring Telek, WEA Records 903172999-1, Disc; WEA Records 903172999-2, CD.

—, 1991a. The Kiap Song, WEA Records 903174427-4, Cassette.

—, with Moab String Band 1991b. Pila Pila, WEA Records 903173847-4, Cassette.

Pink Floyd, 1972. 'Absolutely Curtains' (track 10), Obscured by Clouds, EMI CDP 746385 2, Compact disc.

Raun Raun Theatre, 1996. 'Mourning song' (track 8), To Have and To Hold, Original Motion Picture Soundtrack, Icon 19964, Compact disc.

Sanguma, 1978. 'Yalikoe' (track A1), Sanguma, National Arts School NAS-1, Cassette. Re-issued by Chin H. Meen Papua New Guinea, 1980.

Zemp, Hugo, 1973. 'Lullaby, rorogivela, sung by Afunakwa' (track 8), Fataleka and Baegu Music; Malaita, Solomon Islands, 1973. UNESCO Collection, Musical Sources, The Primeval Cultures, I-1. Disc. 


\section{Index}

A

Access regimes 24, 143-67, 171-3

code of conduct for collection

154, 157-8

prior informed consent 145,152 ,

$162-3,174,178-80$

(see also Materials transfer

agreements, Benefit sharing)

Agricultural policy 128-9

Anthropological perspectives 17-19

exchange 17-18, 102-3

property relations 54-7

reciprocity $99,102-3$

role of researchers 99-101, 104-

6, 111-12

Anthropology in PNG 102

Araguna people 169

Archaeology 107-8

Archaeological sites 92, 97-9

B

Benefit sharing 16, 40, 139, 163-5,

$177-8$

distribution mechanisms 164

royalties $139,151,163,170,173$

(see also Access regimes)

Biodiversity $13,40,125,153$

Bioprospecting 125, 127-8, 150-3, 156-66, 169-71

Biological materials 15, 40, 42

food crops 127,143

indigenous ownership 132

intellectual property protection

$128,145-7,153-4,166-7$ national sovereignty over 130 , 151,176

ownership and access 140, 144-5, 170-3

plant genetic resources $125-6$

protection under PNG law 129

Biotechnology 33-4, 44, 51, 131,

$136,148,166$

C

Capson, Todd 139

Certificate of origin schemes 181-2

Certification marks 39

timber certification 39

Colonial period 3, 83-8

and anthropology 100, 102

Compensation 57

Constitution of PNG 20, 106, 167

Convention on Biological Diversity 14-15, 40-2, 47, 129-30, 132, $134,145,148-9,158,182$ and WTO/WIPO 42, 44

indigenous knowledge 145

Copyright 7, 37-8, 104-5, 154 authors' rights 11

Berne Convention on Copyright

$11,13,44$

enforcement 37

music 62

PNG Copyright legislation 38,

62-3, 120

software 20

Statute of Anne 7-8

Creutzfeldt-Jacob Disease 137 
Cultural property 63 as objects $81-2,85-6,89-90$ control and ownership 106, 112 definition of $63-4,85-6,92-3$ equated with natural resources 96 expropriation and removal 82 , 84-6, 90-1

history of concept $83-87$ national cultural property $88-91$

National Cultural Property (Preservation) Act 81-94 rationale for protection $87-8$ sale of 113

UNESCO Convention 92-3

World Heritage Convention 923, 107

Customary law 20-1

in courts 21

Native Customs (Recognition) Act 20

D

Department of Environment and Conservation 129

Developing countries 44-5, 143, 150 and TRIPs agreement 12-14, 43

DNA 33

$\mathrm{F}$

Farmer's rights 134,152

Folklore 63, 80

Foundation of the Peoples of the South Pacific 139

G

General Agreement on Tariffs and Trade 3, 12-13, 149 deregulation of trade 3

Genetic resources codes of conduct for collection 131 exchange 150 germplasm collections 126 human genetic resources 140 International Undertaking on Plant Genetic Resources 130-1, $144-5$

ownership by State 153

patents 153

(see also Biological materials)

Globalisation 3, 49, 78

Golson, Jack 97-9, 107

$\mathrm{H}$

Hagahai people 137

Human Genome Diversity Project 137

Huon Terraces 92

I

Indigenous art 37, 92

Indigenous knowledge 1-3

access 19-20, 24

alienation 16

and intellectual property law 15 , $40,47,50,63,133$

bioprospecting 34-5, 152

communal ownership 21, 39, 51$3,63-4,78,170-3$ depository databases 155,178 ethnobotanical knowledge 136, 138,150

licensing $24,163,170-3$ outside researchers 104-6 ownership of ideas 96-112 ownership and reciprocity 99 103

production, acquisition and ownership 22, 42, 55-8, 64-72, 111-12, 153-4, 171-3 secrecy $65-8$ tradition and creativity 9 trade secrets 32, 152, 156 value $49,140-2$ (see also Tolai knowledge) 
Industrial property

Paris Convention 10, 13, 44, 146

Intellectual property

and plant genetic resources 128 ,

151

definition $6,8,23,29$

history 4-10, 47, 52

innovation 102

in Melanesia 52, 101-2, 121

Tolai systems of ownership 64

Intellectual property rights $23-5,29$

30

biological materials 15-16

community rights systems 155 ,

173-5

critique 50-1

definition and categories $6-8,9$

11, 31-9

prior informed consent 179-80

rationale for 30-1, 48-9

usefulness for local communities

41, 44-5, 143-4

(see also Sui generis systems,

Certificate of origin schemes)

International Collaborative

Biodiversity Group 169

International law 24, 48, 50

Treaties 10-16, 39-44, 144-9

K

Kuk archaeological site 92, 97-112

L

Land ownership 67, 99,

at Kuk historic site 107-11

Literary property 8,37

M

(see also Copyright)

Materials transfer agreements 40 ,

$139,157-8$

(see also Access regimes)
Merck-Inbio Agreements 153

Music 116-22

manipulation of recordings 119

use of PNG music overseas 118-

20

use of overseas music in PNG

118-19

(see also Copyright)

$\mathrm{N}$

National Agricultural Quarantine

and Inspection Authority 129

National Botanical Gardens 127

National Cultural Commission 121

National Museum 88-93

National Research Institute 122

$P$

Patents $7,11,32-4$

biological processes and materials

33-4, 133, 146-7, 166

(see also Biotechnology)

Budapest Convention 146

developing countries 35

Patent Cooperation Treaty 44, 146

petty patents 35

plant varieties (See Plant breeders rights)

Rome Convention 12

Strasbourg Agreement 146

Pharmaceuticals $34,127,136-42$, 151,159

Plant breeders rights 34, 36, 133, 147 UPOV Convention 147

Property 4-6, 48

commodification 60, 94, 101

communal ownership $21,39,51$ 3

in English law 5-6, 52-4, 59-60

in Roman law 5-6 
$\mathrm{R}$

Research and Conservation

Foundation 139

Researchers in PNG 99-101, 104-6,

111-12, 122

academic research agreements

138-9, 161-2

code of ethics 152,154

$S$

Strathern, Andrew 99-100, 107

Sui generis systems $24,45,131-3$,

$152,155,170-8$

elements 175-8.

$\mathrm{T}$

Technology transfer 40, 145, 148-9,

164

Tolai knowledge 64-80

acquisition 69-72

clans $64,67,74-5$

group knowledge $74-5$

healing $66,72-3$

individual knowledge 72-3

Kabakavir music 76-8

public knowledge 75-8

secrecy $65,66-8$

supernatural forces $65-8$

teaching 69-70

tubuan 65-8, 74-5, 76-8

Trademarks 38-9

Madrid Agreement 12, 44

Registrar of Trademarks 39

Trade Secrets 31-2, 154

Traditional Resource Rights 23, 53,

173-4

TRIPs Agreement 12-14, 43-4,

131-2, 149, 155

$\mathrm{U}$

University of Papua New Guinea 138
University of Technology (PNG) 138 W

World Intellectual Property

Organisation 12, 42

World Trade Organisation 12-13,

42, 149 